\title{
AFRICAN-AMERICAN STUDENTS' PERCEPTIONS OF THEIR EXPERIENCE IN CONTINUATION SCHOOLS
}

By

Shyrea J. Roberson

\begin{abstract}
A Dissertation Submitted in Partial Fulfillment of the Requirements for the degree of

Doctor of Education
\end{abstract}

\author{
School of Education \\ University of Redlands
}

April, 2011

Dissertation Committee Chair: Ron Morgan, Ed.D. 


\section{UNIVERSITY OF REDLANDS}

\section{SCHOOL OF EDUCATION}

This dissertation, written by

\section{Shyrea Roberson}

Under the direction of the dissertation committee and approved by all its members, this dissertation has been approved in partial fulfillment of the requirements for the degree of DOCTOR OF EDUCATION.

Dissertation Committee Signatures

Ronald Morgan, Ed.D., Chair

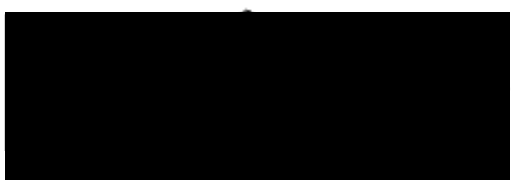

Robert Denham, Ph.D., Committee Member

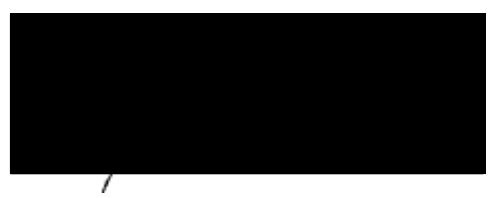

Ronald Williams, Ed.D., Committee Member 


\begin{abstract}
From a Critical Race Theory perspective (Ladson-Billings \& Tate, 1995), this study examined the perceptions of experiences of African-American students enrolled in two different continuation high schools (a traditional continuation school and a nontraditional continuation with a residential component attached). This was done to measure success from the students' point of view. Students who are at-risk of failing in the education system are often enrolled in alternative education programs, which is many times a last chance effort in helping them achieve academic success (EdSource, 2008a). These programs can be administered by a school district or by a private business. The most common alternative education programs are continuation schools, which focus on school-to-career education, individualized instructional strategies, intensive guidance and counseling, and flexible school schedules to meet student needs who are at-risk of not graduating. In California, “in October 2008, there were 525 continuation high schools reporting an enrollment of 70,937” (California Department of Education (CDE), 2010c). Eleven percent of continuation high school attendees are African American (EdSource, 2008a), and the percentage of African-American students who attended public high schools in California in 2008-09 was 7.9\%. African-American students' perceptions of their continuation school experiences were the main focus of this study. The findings of this study showed that African-American students rated their perceptions of experiences in a traditional and a non-traditional continuation high school more positively than negatively. When comparing the perceptions of students in a traditional continuation high school and a non-traditional continuation high school, the traditional continuation high school attendees rated their experiences somewhat less favorably than students attending the non-traditional continuation school.
\end{abstract}




\section{ACKNOWLEDGEMENTS}

Thank you God. He continues to give me strength. I would like to thank my parents, , and all of my family for their support in all of my educational endeavors.

It looks like we crossed the ocean dad._, thank you for your continued

encouragement and words of wisdom. $\square$, you were always so supportive through the laughs and tears. I thank you my love.

I would also like to thank my committee chair and mentor Ron Morgan who continues to challenge and inspire me. Thank you to my committee, Bob Denham and Ron Williams, for all of their work and knowledge that they channeled my way which helped guide me through this process. And to talks and drill sergeant like motivational skills that were much needed at times. Thank you my friend. 


\section{TABLE OF CONTENTS}

SIGNATURE PAGE

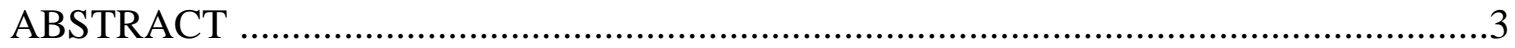

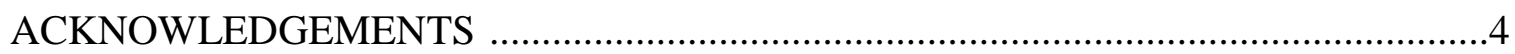

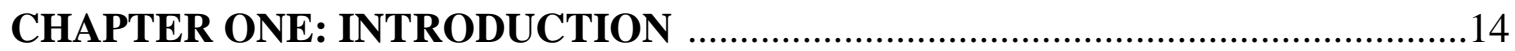

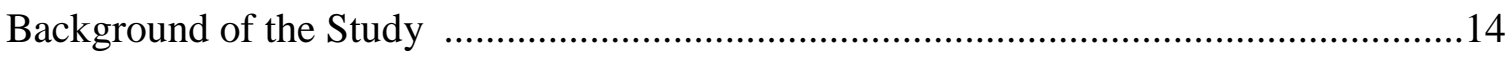

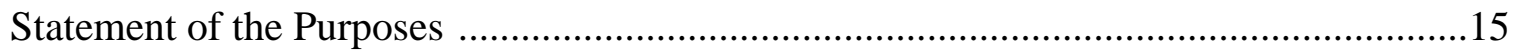

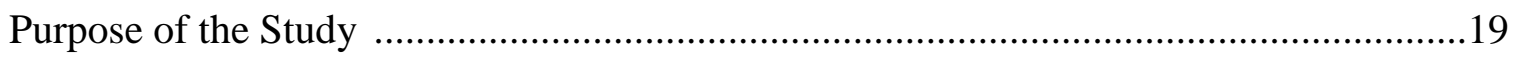

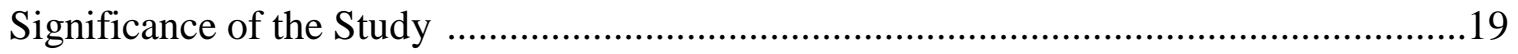

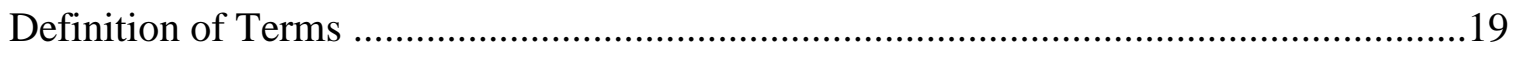

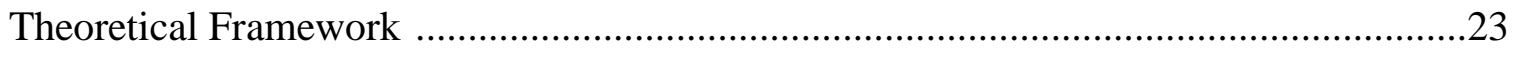

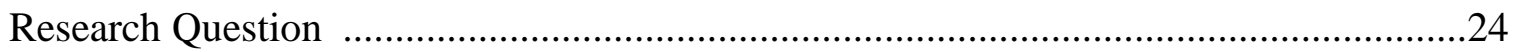

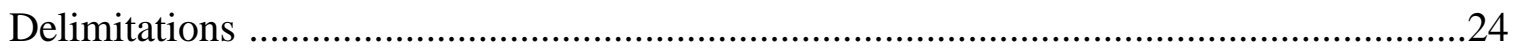

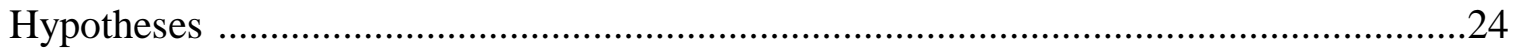

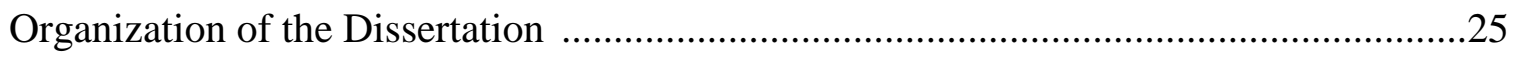

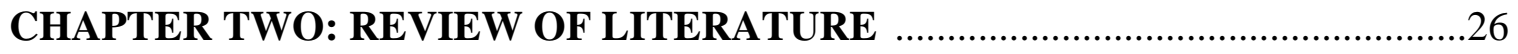

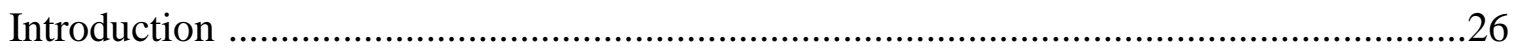

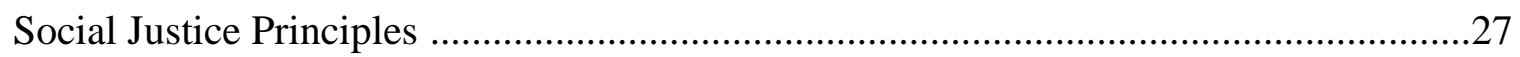

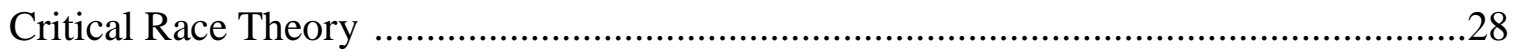

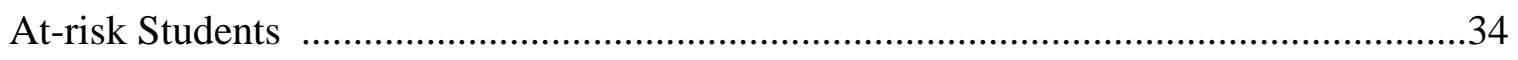

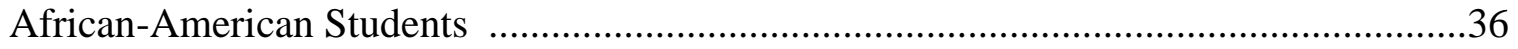




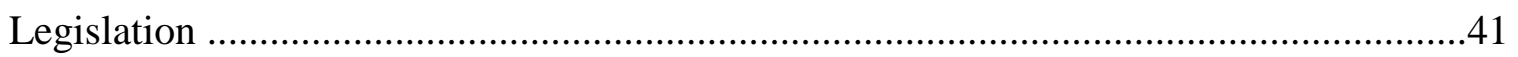

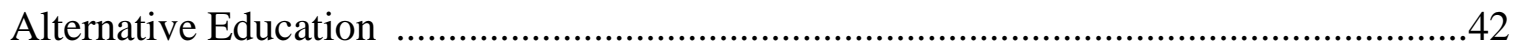

Historical Overview of Alternative Education .............................................4 43

Types of Alternative Education Programs ..................................................47

Research and Alternative Education Programs ............................................48

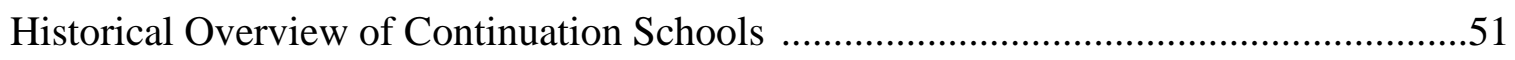

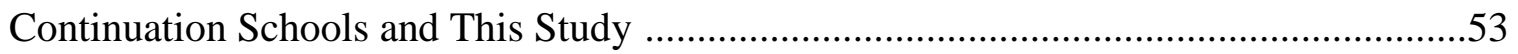

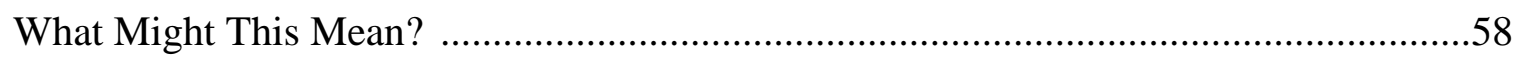

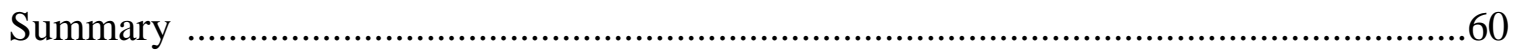

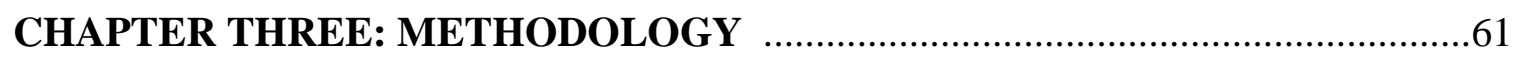

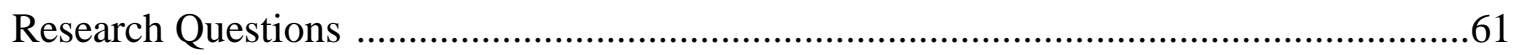

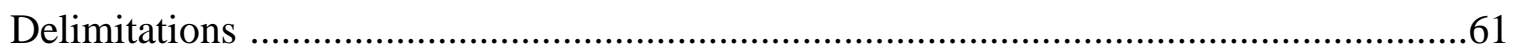

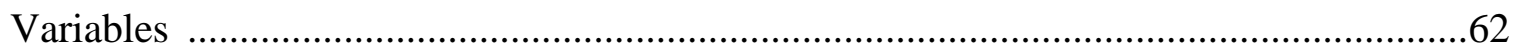

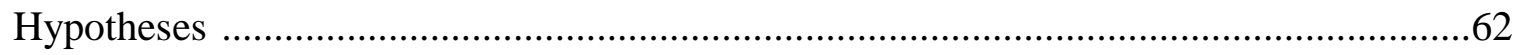

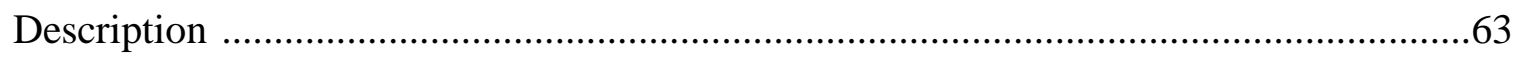

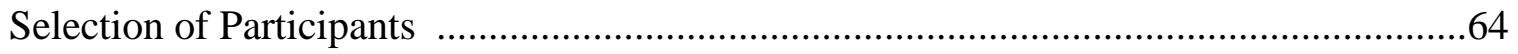

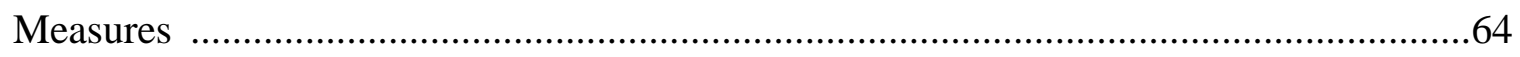

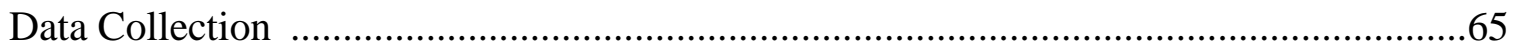

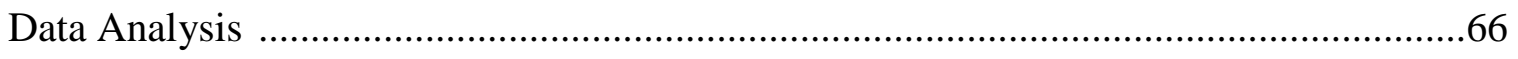

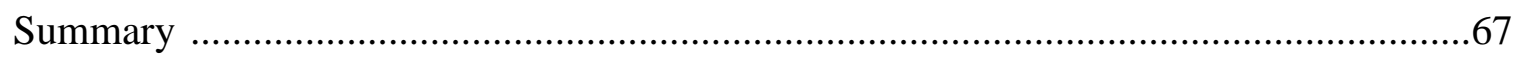

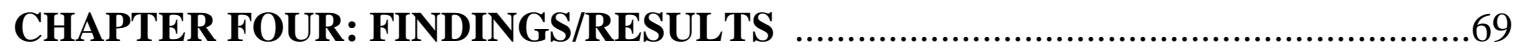

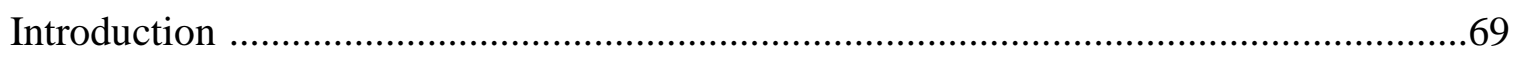

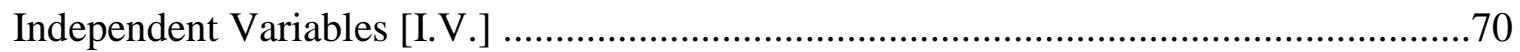




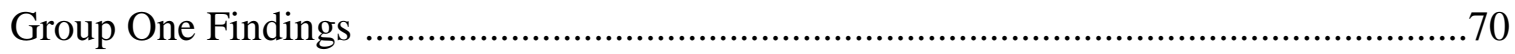

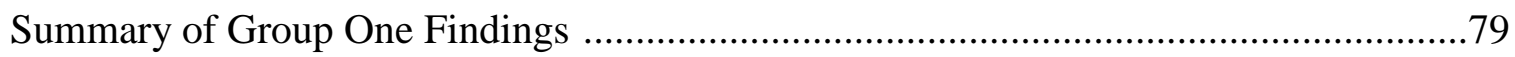

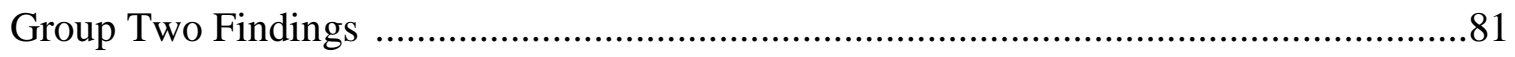

Summary of Group Two Findings ………....................................................................

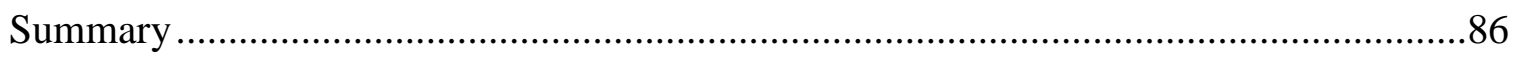

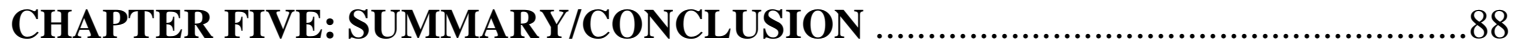

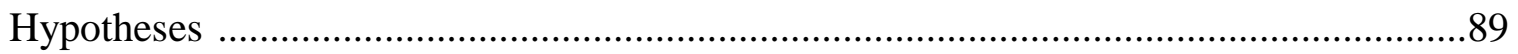

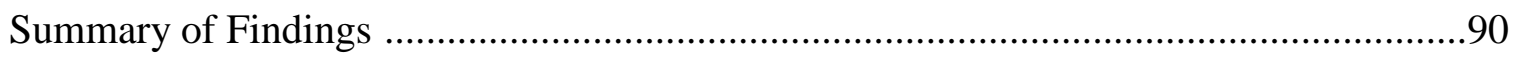

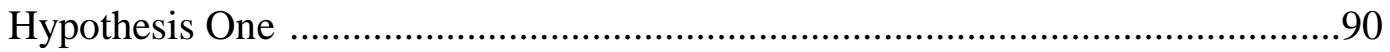

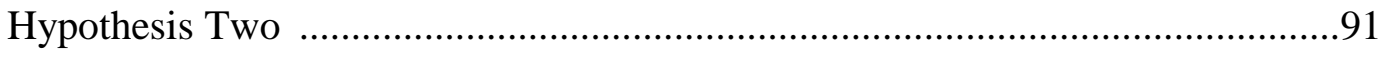

Hypothesis Three ……………….............................................................92

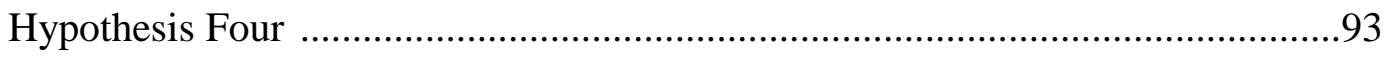

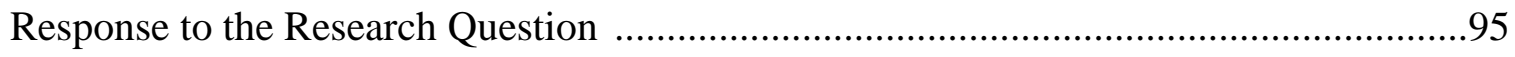

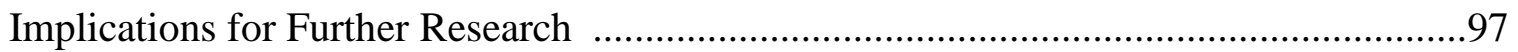

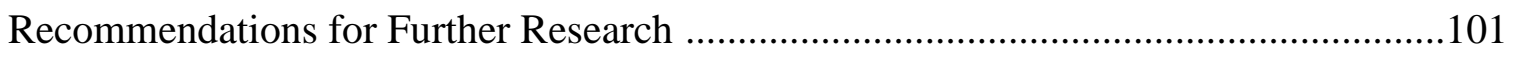

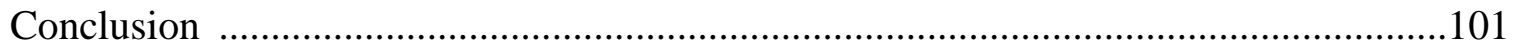

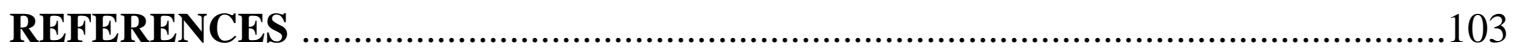




\section{TABLES}

Table 1 - Student Demographics: Traditional Continuation High School A

Table 2 - Student Demographics: Non-Traditional Continuation High

School B

Table 3 - Student Participants

Table 4 - Factor Loadings for Exploratory Factor Analysis with Oblimin

with Kaiser Normalization in Principal Rotation Component

Analysis

Table 5 - Summary of Group One I.V.1 (reason for attending a

continuation school) Mean, Standard Deviation, Confidence

Intervals (CI), ANOVA

Table 6 - Summary of Kruskal-Wallis Test Statistics for Q18 and I.V.1

(reason for attending a continuation school)

Table 7 - Summary of Group One I.V.2 (previous school attended) Mean,

Standard Deviation, Confidence Intervals (CI), ANOVA

Table 8 - Summary of Kruskal-Wallis Test Statistics for Q17 and I.V.2

(previous school attended)

Table 9 - Summary of Group One I.V.3 Mean, Standard Deviation,

Confidence Intervals (CI), ANOVA

Table 10 - Summary of Kruskal-Wallis Test Statistics for Q10 and I.V.3

(living situation)

Table 11 - Summary of Kruskal-Wallis Test Statistics for Q19 and I.V.3

(living situation) 
Table 12 - Summary of Kruskal-Wallis Test Statistics for Q9, Q10, Q11,

Q17, Q18 and I.V.3 (living situation)

Table 13 - Summary of Group One I.V.4 (current grade enrolled) Mean,

Standard Deviation, Confidence Intervals (CI), ANOVA

Table 14 - Summary of Kruskal-Wallis Test Statistics for Q9 and I.V.4

(current grade enrolled)

Table 15 - Summary of Kruskal-Wallis Test Statistics for Q11, Q16, Q18, and Q22 and I.V.4 (current grade enrolled)

Table 16 - Summary of Group One I.V.5 (type of continuation school attended) Mean, Standard Deviation, Confidence Intervals (CI), ANOVA

Table 17 - Summary of Kruskal-Wallis Test Statistics for Q16, Q17, and

Q22 and I.V.5 (type of continuation school attended)

Table 18 - Summary of Group Two I.V.1 (reason for attending a

continuation school) Mean, Standard Deviation, Confidence

Intervals (CI), ANOVA

Table 19 - Summary of Group Two I.V.2 (previous school attended) Mean,

Standard Deviation, Confidence Intervals (CI), ANOVA

Table 20 - Summary of Group Two I.V.3 (living situation) Mean,

Standard Deviation, Confidence Intervals (CI), ANOVA

Table 21 - Summary of Group Two I.V.4 (grade currently enrolled) Mean,

Standard Deviation, Confidence Intervals (CI), ANOVA 
Table 22 - Summary of Kruskal-Wallis Test Statistics for Q12, Q14, Q15 and I.V.4 (grade currently enrolled) 135

Table 23 - Summary of Group Two I.V.5 (type of continuation school attended) Mean, Standard Deviation, Confidence Intervals (CI), ANOVA .136

Table 24 - Student Respondent Percentages of Question Variables Q9-Q22 .137 


\section{FIGURES}

Figure 1 - Wiest, Wong, and Kreil (1998) Study Participants 138

Figure 2 - Student Responses to Q9 for School A

Figure 3 - Student Responses to Q9 for School B 140

Figure 4 - Student Responses to Q10 for School A

Figure 5 - Student Responses to Q10 for School B .142

Figure 6 - Student Responses to Q11 for School A 143

Figure 7 - Student Responses to Q11 for School B 144

Figure 8 - Student Responses to Q16 for School A .145

Figure 9 - Student Responses to Q16 for School B .146

Figure 10 - Student Responses to Q17 for School A .147

Figure 11 - Student Responses to Q17 for School B .148

Figure 12 - Student Responses to Q18 for School A

Figure 13 - Student Responses to Q18 for School B .150

Figure 14 - Student Responses to Q19 for School A .151

Figure 15 - Student Responses to Q19 for School B .152

Figure 16 - Student Responses to Q22 for School A .153

Figure 17 - Student Responses to Q22 for School B .154

Figure 18 - Student Responses to Q12 for School A .155 
Figure 19 - Student Responses to Q12 for School B .156

Figure 20 - Student Responses to Q13 for School A .157

Figure 21 - Student Responses to Q13 for School B .158

Figure 22 - Student Responses to Q14 for School A 159

Figure 23 - Student Responses to Q14 for School B .160

Figure 24 - Student Responses to Q15 for School A .161

Figure 25 - Student Responses to Q15 for School B 162

Figure 26 - Student Responses to Q20 for School A 163

Figure 27 - Student Responses to Q20 for school B .164 


\section{APPENDICES}

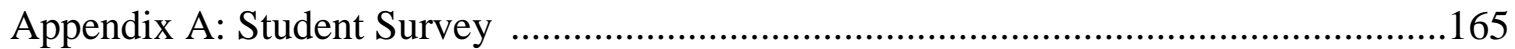

Appendix B: Informed Consent Letter - Student ………….......................................168

Appendix C: Informed Consent Letter - Parent ............................................................170

Appendix D: District Approval Letter - School A ……………………………............172

Appendix E: District Approval Letter - School B ............................................................173

Appendix F: Some Student Responses to Open-Ended Questions .................................174 


\section{CHAPTER ONE \\ INTRODUCTION}

\section{Background of the Study}

Students who are at-risk of failing in the public education system are often enrolled in alternative education programs, specifically a continuation school, which is often a last chance effort in helping them achieve academic success. These programs can be administered by the district or by private businesses. According to the National Center for Education Statistics (NCES, 2010), 64\% of the responding districts nationally reported having an alternative school or program for students at-risk of failing. Additionally, $35 \%$ of those schools reported that at least one of the programs was administered by an entity other than the district. In the 2007-08 academic school year nationally, 10,300 district-administered alternative education programs were available for students who were classified as at-risk of failure. During this academic year, nationally there were 646,500 students enrolled in public school districts that were attending alternative education programs. Of the 646,500 students enrolled in alternative education programs, 558,300 students participated in district-administered programs and roughly 87,000 participated in programs administered by private entities (NCES). Currently, there does not exist a streamlined systematic way to characterize the various types of alternative education programs (Aron, 2006, cited in NCEE).

In regard to continuation schools when examining their place in the state of California, "continuation high schools remain among the most understudied sub-sector of secondary education in California (and nationally)" (De Velasco, 2008, p. 2). Unfortunately, this can often lead to confusion as education teams acting in the best 
interest of students attempt to place students in programs for support and success. The teams' efforts in effectively placing students in various alternative education programs is necessary and relies on accurate information to ensure success of students who require education services outside of traditional public education.

According to Rumberger and Gandara (2004) there are seven "inequitable conditions" that exist in California schools and affect the opportunities of many students. Those conditions included inequitable access to well-trained teachers, poor professional development opportunities for teachers, poor access to proper assessment tools, poor instruction time, poor access to instructional materials/curriculum, inequitable access to sufficient facilities, and segregation which places them at higher risk for academic failure. These conditions can cause students to require education services in an alternative education setting. This is a potential reason for the high number of alternative education programs currently in existence today. Unfortunately, or fortunately depending on how you view the issue, there are many more minority students that access education through alternative education programs, specifically continuation schools. According to EdSource (2008a), “continuation students are more likely to be Hispanic, African American, and English Learners” ... and “. . . non-Hispanic White and Asian students are underrepresented in continuation schools" (p. 8).

\section{Statement of the Problem}

Recognizing any patterns that exist, including socioeconomic status (SES), family involvement, and race, which lead students out of traditional public education and into alternative education, specifically continuation schools, is vital to addressing these students' needs. Nationally, the percentage of districts offering alternative education 
programs with $50 \%$ or more minority population is high at $73 \%$ when compared to districts with less than a $6 \%$ minority population at 55\% (NCES, 2010). Possible reasons for the increase in the need for alternative education programs in districts with higher minority populations can relate to issues of culture, race, and ethnicity not being addressed in schools. Hence these students are effectively disengaged from the curricular material. According to Banks (2006), this is because we do not have curriculum that is reflective of the diverse groups of students currently being educated in American schools. Banks used Woodson $(1933,1977)$ to make a case for cultural democracy by arguing that the curriculum of African-American students should reflect their history in order to promote cultural democracy. Additionally, Banks argued that cultural democracy can educate students to be effective citizens of their cultural communities, the nation, and the world, whereby they develop the commitment, attitudes, and skills to work to make our nation and the world a just place to live and work. It is this researcher's opinion that this does not occur; instead, we are left with a high number of minority students being exited from traditional public education and placed into alternative education programs.

Students should receive instruction related to becoming democratic citizens in addition to quality curriculum and access to quality teachers. In addition, nationally school districts with a poverty concentration of $20 \%$ or more had a slightly higher percentage of offering alternative education programs $(68 \%)$ when compared to school districts with poverty concentrations of $19 \%$ and below (62\%) (NCES, 2010). From these figures, it appears that districts with higher minority populations and higher poverty concentrations have a higher percentage related to offerings of alternative education programs and these programs may not be of quality. 
Ladson-Billings and Tate (1995) recognized the importance of addressing racial issues in schools. They stated that the failure of the dominant majority to understand that progress cannot be made for students of color because race as a critical issue is not being addressed, and this in fact prevents minority students from succeeding. Howard (2008) used the work of Tillman (2002) to suggest that theoretical approaches such as Critical Race Theory (CRT) seek to illuminate the voices of individuals that have been historically silenced . . . thus providing a counter-script to mainstream accounts of their realities" (p. 956). If we are to attempt to understand students, specifically ethnic minority students, it is necessary that we engage these students in dialogue about their realities.

Ogbu (1981) proposed an economic linkage between schools and the corporate economy when he stated that the public education system is charged with preparing students to be successful in their future economic participation. According to Ogbu, families prepared children to learn what schools will later teach them, including socialemotional skills, language skills, cognitive skills, and motivational skills. Once students begin attending, they learn basic practical skills such as reading, writing, and computation, which Ogbu termed subsistence tasks for every task in the United States' (U.S.) industrial economy. However, what happens when students are not prepared by their parents to learn what schools will later teach them? Those students then must acquire social-emotional skills, language skills, cognitive skills, and motivational skills along with reading, writing, and computation during their first years in schools; thus causing them to fall behind their classmates. 
Students who lack support at home are considered to be educationally disadvantaged; as they often begin school without basic communication skills that other students bring with them. According to Levin (1990), students found themselves trying to catch up to their more advanced counterparts. Because of this disadvantage, ethnic minority students are unable to perform on tests that measure academic achievement, because of the lack of familiarity with the dominant discourse of academic English. This can lead ethnic minority students out of the traditional education system because of the assessment measures currently in place that link to accountability. Yet, research that suggests that assessment tests alone are inaccurate in measuring student success is often ignored.

Students who generally transfer into alternative education, specifically into a continuation school setting, include those who are at-risk of educational failure related to poor grades, credit deficiency, or other factors that may cause the student to temporarily or permanently withdraw from school. (Carver \& Lewis, 2010, p. 1)

Currently, there appears to be a gap in the research in the area of continuation schools in California. At present, continuation schools exist to provide students with a means of success outside of the traditional public school system, yet this is difficult to measure (reasons discussed in Chapter Two). This dissertation will address a part of the gap in research related to perceptions of minority [African-American] students in continuation schools on their current and future success. 


\section{Purpose of Study}

The purpose of this study was to review historical data of African American students' experiences in education to show a pattern of disengagement from traditional public education. Contributing factors of poor family system structure, poverty, and lack of parental engagement experiences will be explored through a survey of AfricanAmerican students. The second purpose of this study was to document the experiences of African-American students in continuation school. Two continuation high schools in the of Southern California were utilized for this study.

\section{Significance of Study}

This study examined the relationship between attending a continuation high school and the degree of students' perceptions about whether they are supported and engaged in education. The results showed how favorably the students viewed their experiences in a continuation school compared to their previous school experiences. Further, the study provided a foundation for further questioning and research to consider what happens after those students graduate, in terms of college attendance, employment and earnings, etc. This study has implications for how students are identified for alternative education and subsequently educated.

\section{Definition of Terms}

Although the different types of alternative education programs were not the focus of this dissertation, following is information about various types of alternative education.

- At-risk Students: According to California Education Code 54690 section (d), “. . . 'at-risk' students means students enrolled in high school who are at-risk of dropping out of school, as indicated by at least three of the following criteria: 
(1) past record of irregular attendance, (2) past record of underachievement in which the student is at least one year behind the coursework for the respective grade level, (3) past record of low motivation or a disinterest in the regular school program, and (4) disadvantaged economically (CDEd, n.p.).

- Othering: “. . . refers to those groups that are traditionally marginalized in society, i.e., that are other than the norm, such as students of color, students from underor unemployed families, students who are female, or male, but not stereotypically 'masculine,' and students who are, or are perceived to be, queer" (Kumashiro, 2000, p. 26).

- Banking Model of Education: According to Freire (1970), the Banking Model of Education is when knowledge is bestowed or deposited by those who consider themselves knowledgeable (teacher) upon those who they consider to know nothing (student). Students then accept the knowledge, memorize it, and repeat it for a grade. Students no longer are required to show skills at interpreting material or relating material to lived experiences.

- Voice: Provides a way to communicate the experience and realities of the oppressed through parables, chronicles, stories, counter-stories, poetry, fiction, and revisionist histories (Ladson-Billings \& Tate IV, 1995).

- Privilege: Privileging of Whites in all aspects of society over minority populations (Ladson-Billings \& Tate IV, 1995).

- Racial Identity Theory: “. . . the examination of the extent to which people of color perceive themselves to share a common racial heritage with their ascribed racial group" (Helms, 1990, cited in DeCuir-Gunby, 2009, p. 103). 
- Black Racial Identity (BRI): "BRI can be described as the attitudes and beliefs that an African American has about his or her belonging to the Black race individually, the Black race collectively, and their perceptions of other racial groups" (DeCuir-Gunby, 2009, p. 103).

- Alternative Education: Per Aron (2006, cited in NCES, 2010), alternative education consists of any schooling that is not considered to be K-12 traditional public education.

- Continuation Schools: “. . . serve students aged 16 years or older who lack sufficient school credits and are at-risk of not graduating. These schools focus on school-to-career education, individualized instructional strategies, intensive guidance and counseling, and flexible school schedules to meet student needs" (California Department of Education, 2010b, n.p.).

- Charter Schools: "Public schools that may provide instruction in any of grades K12 that are created or organized by a group of teachers, parents, community leaders, or a community-based organization" (CDE, 2010d, n.p.).

- Community Day Schools: “. . . operated by school districts and county offices of education. Community day schools serve mandatory and other expelled students, students referred by a School Attendance Review Board and other high-risk youths" (CDE, 2010d, n.p.).

- Distance Learning Schools: According to the CDE (2010d), these programs are offered via the internet and other technologies and deliver high-quality career technical curriculum and career exploration to students who previously have not had access to these classes. 
- Non-public Schools: According to the non-public schools fact sheet found on the California Alliance for Child and Family Services website, non-public schools are privately operated, publicly funded schools that specialize in providing educational services for students with special education needs so exceptional that they cannot be met in a public school setting (No Author, n.d.).

- Juvenile Justice Schools: “. . . provide mandated, compulsory public education services for juvenile offenders who are under the protection or authority of the county juvenile justice system and are incarcerated in juvenile halls, juvenile homes, day centers, juvenile ranches, juvenile camps, or regional youth educational facilities. Juvenile court schools are operated through the county office of education" (CDE, 2010d, n.p.).

- Independent Study Schools: “. . . an alternative educational instructional strategy for students in kindergarten through adult education who may be gifted, have special challenges, need targeted instruction, or want an individualized approach to education. Students work on their own according to written agreements and under the general supervision of credentialed teachers. While independent study students follow the district-adopted curriculum and meet the district graduation requirements, independent study offers flexibility to meet individual students' needs, interests, and styles of learning" (CDE, 2010d, n.p.).

- Non-traditional Continuation School: For the purpose of this dissertation, a nontraditional continuation school is defined as any continuation school setting that provides residential placement for students, where students may or may not be wards of the court, have behavioral needs over and above what a traditional public 
high school can accommodate, or have involvement with the juvenile justice system. These schools do focus on “... school-to-career education, individualized instructional strategies, intensive guidance and counseling, and flexible school schedules to meet student needs" as outlined by the CDE website (CDE, 2010b, n.p.).

- Traditional Continuation School: For the purpose of this dissertation, a traditional continuation school model is one that aligns directly with the CDE (2010b) definition that follows: “. . . serve students aged 16 years or older who lack sufficient school credits and are at-risk of not graduating. These schools focus on school-to-career education, individualized instructional strategies, intensive guidance and counseling, and flexible school schedules to meet student needs" (CDE, n.p.).

\section{Theoretical Framework}

Using Critical Race Theory (CRT) to understand the voices of African-American students was essential for this study. Ladson-Billings and Tate (1995) recognized the importance of addressing racial issues in schools. They stated that the failure of the dominant majority to understand that progress cannot be made for students of color because race as a critical issue is not being addressed, and this in fact prevents students from succeeding. CRT began as a movement in the law; however, educators utilize CRT to enhance their understanding of the dynamics among students in their classroom, academic testing, and curriculum bias (Delgado \& Stefancic, 2001). The foundations of CRT are further elaborated upon in Chapter Two. 


\section{Research Question}

What are the experiences of African-American students who attend continuation schools related to self-esteem, education-previous, current, and post continuation school placement—and does this affect their outlook on their futures?

\section{Delimitations}

1. This study will not examine the effectiveness of one alternative education setting over another; for example, the effectiveness of a continuation school versus that of a charter school.

2. Generalizability of the research study is not known. Because the phenomena exists at the research sites for this study, does not mean that it will be able to be duplicated at other sites with similar results.

3. Discussion of the perceptions of all minority populations will not be reviewed; only that of African-American students. Again, generalizability of results to other minority populations will not be researched.

\section{Hypotheses}

1. Students with discipline issues will rate their continuation high school experiences more positively than negatively.

2. Students with reportedly low parent/caregiver involvement will rate their continuation high school experiences more positively than negatively.

3. Student responses to survey questions will be more positive than negative as they rate their perceptions of their continuation school teachers. 
4. Students in a non-traditional continuation high school will respond more positively than negatively about their continuation high school experiences when compared to students in a traditional continuation high school.

\section{Organization of the Dissertation}

The remaining parts of the dissertation include a review of the literature related to social justice principles, Critical Race Theory (CRT), at-risk students, African-American students' education experiences, and alternative education-specifically continuation schools upcoming in Chapter Two. Following this chapter, there will be included a discussion of the methodology employed by this researcher with participants, procedures, instruments, measures, a description of data collection procedures and the data analysis measures that were employed. Finally, there will be the presentation and analysis of the data collected in Chapter Four, and a summary of the study, findings, implications, and any recommendations for further research in Chapter Five. 


\section{CHAPTER TWO}

\section{LITERATURE REVIEW}

\section{Introduction}

For over a century, educational theorists such as Dewey (1916) and Freire (1970) have called for the reform of the education system to make it a system that creates freedom by bringing a humane future to life against and within an unjust present. Yet these calls for reform have not been met and instead the current system of education continues to place emphasis on practices that advantage the dominant majority and marginalize and oppress the subordinate minorities. This practice can be seen within the classroom structure that exists today, where Giroux (2009) stated, “. . . thinking is removed from implementation and the model of the teacher becomes that of the technician or white-collar clerk" (p. 180). These practices have extreme implications for future success of minority students who are not able to immerse themselves fully in the curricular material because they are no longer allowed to think or produce knowledge out of what they are given. Because of this, many minority students are no longer able to progress through the current traditional public education system and are forced to finish school in an alternative education setting.

This literature review begins with an examination of Social-Justice literature that discusses how the current education system can facilitate moving students out of traditional public education and into alternative education. The remainder of the literature review focuses on the rise of alternative education including continuation schools; and there is discussion of the type of student that generally accesses alternative education, specifically continuation schools. Our attention will then shift to African- 
American students in education. Additionally, throughout this chapter, research on alternative education schools and continuation schools will be presented and reviewed.

\section{Social Justice Principles}

A main problem with education in its current form is that it relies upon what Freire (1970) called the "banking model of education." According to Freire, this concept refers to the bestowing of knowledge by those who consider themselves knowledgeable upon those who they consider to know nothing (i.e. - teacher/student). This process negates education and knowledge as a process of inquiry; in essence we are teaching students what to think instead of teaching them how to think and how to ask why. Also through this model, teachers are seen as depositors and students become receptacles for the information that is narrated to them by teachers. Students no longer are required to show skills at interpreting material or relating material to lived experiences, instead they are expected to only memorize this information and repeat it verbatim in order to be classified as proficient. Freire proposed a solution to the banking model of education that has been employed for decades, termed "problem-posing education." Involved in this concept is the notion that dialogue between teachers and students is the way in which students learn. According to Freire, through dialogue, the teacher-of-the-students and the students-of-the-teacher cease to exist and teacher-students and student-teachers emerge. In problem-posing education, the teacher is no longer the only one who teaches, but also is taught through dialogue with the students. While this seems like a simple concept to employ, it is rarely used by educators as they fear losing power over their students. Thus, reinforcing the hegemonic power structures we currently have in place in society. It is this researcher's opinion that should schools continue to operate in their current and most 
oppressive form, students will continue to be left behind and be forced to seek education outside of the traditional public education setting.

Freire's (1970) thoughts on problem-posing education were expanded upon by Giroux (1988) who called for improvement in teacher education programs in order to teach educators to be transformative intellectuals. According to Giroux,

the term transformative intellectual refers to an individual who exercises forms of intellectual and pedagogical practice that attempt to insert teaching and learning directly into the political sphere by arguing that schooling represents both a struggle for meaning and a struggle over power relations. In turn, those intellectual practices are grounded in forms of moral and ethical discourse exhibiting the preferential concern for the suffering and struggles of the disadvantaged and oppressed. (pp. 174-175)

Giroux found the grounding of intellectual practices in moral and ethical discourse necessary in order to improve educators' abilities to encourage a critique of the dominant forms of knowledge and social practices in order to give students a voice.

\section{Critical Race Theory}

Giroux (2009) used the work of Mikhail Bakhtin when he said that "voice means ... retelling a story in one's own words" (p. 454). Using voice within the classroom allows students to draw on and confirm the dimensions of their own histories and experiences that are deeply rooted in the surrounding community. Matsuda (1995) suggested that those individuals who have experienced discrimination speak with a special voice to which we should listen. In essence, voice allows students to use their own experiences in order to produce knowledge out of the curriculum they are given, 
where they are allowed to connect the material to themselves and their community.

Allowing students to participate in activities that help them to define their voice can also bring community strengths and issues to light for students to discuss. However, teachers must be careful that they do not expect to find that all minority students have the same voice, as they all have differing lived experiences. Delgado (1990) suggests that although there is not one common voice, there is a common experience of racism that structures the stories of people of color. Only when we begin to understand that students bring experiences with them to school based on their racial, ethnic, and cultural backgrounds and use these experiences in the production of knowledge will we be able to successfully and truly educate all students. Until then, ethnic minority students will continue to be marginalized in schools, thus leading to continued oppression both inside and outside of schools.

Ladson-Billings and Tate (1995) recognized the importance of addressing racial issues in schools. They stated that the failure of the dominant majority to understand that progress cannot be made for students of color because race as a critical issue is not being addressed, and this in fact prevents students from succeeding. When looking at race as a factor of inequality, Ladson-Billings and Tate suggested that it is clear that "... it (race) has become metaphorical—a way of referring to and disguising forces, events, classes and expressions of social decay and economic division far more threatening to the body politic" (p. 49). Race is also critical to explaining inequity because it has become clear that gender- and class-based explanations are not enough to explain the disparities in performance of minority students. According to Dixson and Rousseau (2005) relying on the works of Oakes (1995), Darling-Hammond (1997), and Oakes et al. (2000), African- 
American and Latino students are disproportionately placed into the lowest tracks and afforded fewer educational opportunities as a result.

Ladson-Billings and Tate (1995) also found that property functions of Whiteness could be used to continue to oppress and marginalize minority students. They posited that there were four property functions of Whiteness which include;

The Rights of Disposition-when Whiteness is conferred upon student performances, it is considered alienable. This is because students are rewarded for conformity to perceived 'white norms' or cultural practices, which can be considered property, therefore it becomes alienable;

Rights to Use and Enjoyment-Whiteness is shown in school, related to use and enjoyment, when there are differences between those who possess the right to use and enjoy what schools can offer (Whites) and those who do not (minorities); Reputation and Status Property - this is demonstrated through legal cases of libel and slander, where damaging someone's reputation is to damage some aspect of his/her personal property. In the case of schools, when a school is considered non-white its reputation is diminished;

The Absolute Right to Exclude - this right was demonstrated initially by denying African Americans access to schooling completely and then again by segregating schools. (pp. 59-60)

The authors state that it was more recently demonstrated through resegregation via tracking, institution of gifted and honors programs, and advanced placement classes. From this, it is clear to see the possibility that these concepts can be directly linked to the disproportionate representation of minority students in alternative education settings, 
specifically continuation schools. These students find themselves with no voice or connection to the material as the dominant majority continues to provide curriculum that only perpetuates their dominant place in society while reminding minority students of their subordinate place in society. This perpetuates Dewey's (1916) concepts that education serves as a function of society, in that it creates passive, risk-free citizens; rather than society serving as a function of education in creating a politicized citizenry educated to fight for various forms of public life informed by a concern for justice, happiness, and equality.

Ethnic minority students can be considered educationally disadvantaged, a term taken from Levin (1990). Educationally disadvantaged students—mainly ethnic minority students—often times lack home and community support and generally are not able to reap the rewards of education reforms due to such things as poverty and cultural and/or linguistic differences, which can contribute to low academic achievement. According to Levin, students who fell into the educationally disadvantaged category often began their schooling with lower standardized achievement than their non-disadvantaged peers. In addition, they ranked at about the 15th percentile and remained there throughout their academic careers (Levin). Because of this, these students continue to fall farther behind, and by the time they begin high school they are on average three years behind in grade level. Levin stated that "as a consequence of both their poor achievement and other factors, educationally disadvantaged students have exceedingly high dropout rates ..."(p. 3).

This work of creating critical questioners and thinkers in society further links to the work of Shor (1999) who called for critical literacy curriculum in classrooms to 
construct students who are critical thinkers. According to Shor, critical literacy seeks to examine our ongoing development, to reveal the subjective positions from which we make sense of the world, and act in it. By failing to employ critical literacy in education, we fail to recognize that students have the capacity to inform the curricular discourse with their voices, as they come to school with rich experiences and cultures. Instead, we use current methods of standardization to continue to keep certain individuals in power and others without the means to communicate effectively their distinct experiences with oppression and marginalization; thereby continuing the vicious cycle of injustice and inequity to our most vulnerable individuals. Shor further gave examples related to the ways which failing to use critical literacy by the dominant majority further subordinate minorities to maintain power and perpetuate the status quo. Ultimately without the employment of critical literacy, students will never develop the ability to use their own voice.

Kumashiro (2000) discussed ways to improve the experience of students who exist outside of the dominant majority and thus are considered as others. Kumashiro's theory of Anti-Oppressive Education focuses on four approaches to improve the education experiences of students considered to be others. They are Education for the Other, Education about the Other, Education that is Critical of Privileging and Othering, and Education that Changes Students and Society.

According to Kumashiro (2000), Education for the Other “... focuses on improving the experiences of students who are Othered, or in some way oppressed in and by mainstream society" (p. 2). This improvement is done by bringing to light the differences in students' identities in order the aide them in relating to the material. 
Education about the Other focuses on curriculum including specific amounts of information about the Other (i.e. historical facts and information). Secondly, according to Kumashiro (2000), otherness was integrated throughout the curriculum because information about those marginalized groups generally related to many events throughout history. For example, educators could have used math problems to integrate diversity into their curriculum. This would cause the Other to become more normative instead of feeling singled out because lessons were added on to the pre-existing curricula.

Education that is Critical of Privileging and Othering focused on educators and students ... examining not only how some groups and identities are othered, that is, marginalized, denigrated, violated in society, but also how some groups are favored, normalized, privileged, as well as how this dual process is legitimized and maintained by social structures and competing ideologies. (Kumashiro, p. 7)

In this approach, there must be a push for more knowledge about the oppressed. According to Ladson-Billings (1995), “. . . this will help students recognize, understand, and critique current social inequities" (p. 476). According to Giroux (1997) as cited by Kumashiro (2000), we must teach critically to unmask or make visible the privilege of certain identities and the invisibility of this privilege, such as being White or Heterosexual. For example, it is apparent that there is a strong normative thought process in those two privileges.

Education that Changes Students and Society, according to Kumashiro (2000), focused on stopping the repetition of harmful "knowledges," including partial knowledge such as stereotypes and whole knowledges (neo-Marxist grand narratives). Students must 
ultimately learn to participate in looking beyond what is there and what is known to see what is not there. If we can succeed at having students learn to do this, is it not plausible that the need for alternative education programs decrease?

Traditionally, students considered to be at-risk for educational failure belong to a minority group such as African American. Going forward, the focus of this literature review will be on African-American students. In the upcoming sections, issues surrounding both at-risk students and African-American students will be discussed. Moreover, options for these students outside of high school will be reviewed.

\section{At-risk Students}

The term at-risk is used to describe students who are deemed to be at-risk for school failure. There are various reasons why students may find themselves in this category. Some researchers such as Cuddapah, Masci, Smallwood, and Holland (2008) believed it was related to a lack of self-confidence and success in academic endeavors, along with negative behavior patterns of isolation both mentally and physically from the school environment. According to Vesely, Crampton, Obiakor, and Sapp (2008), at-risk students could be placed into six categories of risk, which include students who may need additional resources to be academically successful, and encompass low-income students, students with disabilities, ethnic minority students, English Language Learners (ELLs), children in urban schools, and students from families with low parental education attainment. Vesely et al. proposed that the nature of the risk is increased when a student fell into two or more of the categories of risk as their academic success will be further compromised. For the purpose of this dissertation, the main focus will remain on students who fall into the ethnic minority category of risk. 
Nationally, in $200754 \%$ of fourth grade and $45 \%$ of eighth grade AfricanAmerican students tested at the Below Basic level in reading achievement; while only $14 \%$ of fourth graders and $13 \%$ of eighth graders tested at the Proficient or Above level (U.S. Department of Education, 2010b). The percentage of students performing at or above the Proficient level in reading for 2009 was $15 \%$ and $13 \%$ respectively for fourth and eighth grade African-American students (U.S. Department of Education). The 2009 figures were similar to those of 2007 and only marginally better for fourth grade students, with fourth and eighth grade African-American students scoring $14 \%$ and $13 \%$ respectively (U.S. Department of Education, 2010c). Yet the achievement level in reading for the state of California is slightly lower than the national percentage with $14 \%$ of fourth graders scoring at the Proficient level or Above and $11 \%$ of eighth graders scoring at the Proficient level or Above. In 2005, 46\% of twelfth grade AfricanAmerican students tested at the Below Basic level in reading achievement with only $16 \%$ of students testing at the Proficient level or Above (U.S. Department of Education, 2010d).

In mathematics, similarity exists in how students performed on standardized testing; however, fourth graders appear to have performed slightly better. According to the U.S. Department of Education (2010d), 36\% of fourth grade and 50\% of eighth grade African-American students tested at the Below Basic level in mathematics achievement; while $16 \%$ and $12 \%$ respectively tested at the Proficient or Above level nationally. In the state of California, only $13 \%$ of fourth graders and $10 \%$ of African-American students tested at the Proficient level or Above in mathematics (U.S. Department of Education, 2010b). For twelfth grade African-American students, performance was far worse. In 
2005, 70\% of twelfth grade African-American students tested at the Below Basic level; while only $6 \%$ tested at the Proficient level or Above. For possible reasons why these students are falling behind, let us now look at the journey of the African-American student in education.

\section{African-American Students}

Prior to 1954, African Americans were educated separately from their White student counterparts. With the Brown v. Topeka Board of Education (1954), racial discrimination in schools was considered unconstitutional and schools were desegregated in hopes of promoting equality between the education of minority and White students (Alexander \& Alexander, 2005). There continues to be a gap in achievement between African-American students and their White counterparts in education when tested in reading and mathematics.

According to Vanneman, Hamilton, Anderson, and Rahman (2009), "the achievement gap between Black and White students is defined as the difference between the average score for Black students and the average score for White students" (p. 4). Ferguson (2001) cited in Gosa and Alexander (2007) stated the achievement gap narrowed in the 1970 s and 1980 s by approximately $45 \%$ in reading and $33 \%$ in mathematics before it stalled in the 1990s. In California, the eighth-grade reading gap has not changed much since 1998 (Vanneman et al.). In 2007, the results showed an achievement gap in reading of 29 points between African-American and White students, while in 1998 the gap was 30 points (Vanneman et al.). For fourth-grade students, the gap has narrowed by four points since 1998, from 31 points to 27 points. Looking at national data, the progress in closing the achievement gap in reading is even less 
impressive. Looking at trend data from 1992 to 2007, the reading achievement score gap between African-American and White fourth-grade students has narrowed by only 5 points - from a 32-point gap to a 27-point gap in 2007 (Vanneman et al.).

With regard to mathematic test scores, the achievement score gap is slightly larger. In California, the achievement score gap between African-American and White eighth-grade students was 35 points in 2007, compared to the 42-point gap in 1992 (Vanneman, et al., 2009). For fourth-grade students, the achievement gap has narrowed by 10 points since 1992; from a 39-point gap in 1992 to a 29-point gap in 2007 (Vanneman, et al.). Despite the gains just referenced, California remained slightly above the nation's average 26-point and 31-point achievement gaps for fourth-graders and eighth-graders respectively in mathematics (Vanneman, et al.). African-American students continue to perform worse than their White counterparts in reading and mathematics. Could this achievement score gap be the result of differences in socioeconomic status (SES) backgrounds between White students and African-American students? Let us examine this question below.

Gosa and Alexander (2007) found that "even with economic and educational resources in the home, well-off African-American youth are not achieving at the levels of their white peers" (p. 285). Further, Gosa and Alexander believed that African-American students who have resources in the homes (e.g. books) and highly educated parents perform better in school than African-American students who lack such resources. Yet, they still do not perform as well as White students who have similar family dynamics. In fact, the school performance of affluent African-American children often is closer to that of poor White children than that of affluent Whites (Gosa \& Alexander). In reviewing a 
portion of the survey findings from the Minority Student Achievement Network (MSAN) report during 2000-2001—which is a national coalition of multiracial, suburban-urban school districts that have come together to study achievement gaps that exist in their districts (msanetwork.org)—Ferguson (2002) found large disparities in performance between African-American students and White students. For example, Ferguson found that $15 \%$ of African-American students attending MSAN schools reported average grades in the " $\mathrm{A}$ " range, whereas $44 \%$ of African-American students reported averaging grades of "C" or below. Ferguson reported that students' grade reports were checked against recorded documents and minimal inflation of grades was found. Alarmingly, many of the African-American students reported that they only understood their teacher's lesson half of the time or less. Students' achievement can be greatly impacted by their lack of understanding lessons. According to Gosa and Alexander who reviewed Ferguson's research, SES disadvantages account for about half of the MSAN student's academic shortfalls related to standards measures of SES (e.g., parental education, books at home, and household composition). Gosa and Alexander cited Ferguson to show that the achievement gap is better explained by family background disparities when comparing lower SES students to higher SES students. Ogbu (2003) also found this to be true within the African-American community as well as in the White community. Yet, family background disparities cannot be used to explain the achievement gap between AfricanAmerican and White students who come from similar family backgrounds.

Ogbu (2003) reported on disparities in achievement between African-American students and White students in a favorable school environment. He examined the performance of African-American students in a middle-class suburban school district and 
found that while African Americans performed well above national averages, they remained underrepresented in honors and advanced placement classes. Additionally, according to Ogbu African-American students continued to trail behind White students in the district on most of the educational measurements used, including grade point average (GPA) and proficiency tests. Hence, despite comparability in SES backgrounds between Whites and African-American students, there still remains disparity in performance or a gap in achievement. Thus, it can be concluded that SES backgrounds cannot be used as the sole explanation for the achievement gap between African-American and White students. Therefore we should examine race as a factor when attempting to determine why African-American students continue to fall behind their White counterparts in reading and mathematics.

According to Perry, Steele, and Hilliard (2003), there is a general assumption that in education ". . . if you know what works for the white child, then you will know what will work for the Black child" (p. 4). While the authors recognized that there is generalizability in some competencies that are required of and embedded in learning tasks that students must perform, Perry et al. posited that learning is fundamentally contextual and there are other areas unique to the African-American experiences such as social, emotional, cognitive, and political competencies that are required of AfricanAmerican students because they are African American. However, to have this type of discussion about the competencies that must be present within our African-American students, we must be willing to insert race into the conversation. As Perry, et al. stated, the conversation might force an examination of the particular ways in which racism is embedded in 'liberal' integrated educational settings. It might prompt 
discussion about Black achievement that foreground the racial and cultural identities of African Americans. ... (p. 9)

When examining identity development of African-American students, Perry et al. argued that generations of African Americans understood the task of achievement as idiosyncratic and out of the lived experiences came a theory of knowledge and a philosophy of education that faced the dilemma of understanding the task of achievement. Understanding the task of achievement of African-American students can be examined through discussion of social group identity.

The identity of African-American students involves biological and social terms as illustrated by DeCuir-Gunby (2009), however it is the social component that most influences the identity development. According to Melucci (1996) cited by DeCuirGunby, identity is formed through a multifaceted negotiation process where the individual asks questions about their past, present, and future. DeCuir-Gunby used the work of Arnett (2006) and Mitchell (1992) to showcase that identity development occurs over the entire lifespan; however the adolescence period-ages 11 to 22 - is considered to be the most critical. According to Erikson (1950) cited by DeCuir-Gunby (2009), adolescence is a buffer between childhood and adolescence that ". . . bridges the stages of childhood when the bodily self and the parental images are given their cultural connotations ..." (p. 104). DeCuir-Gunby argued that race is an example of the cultural connotations and social roles. Therefore, since race is considered the most significant socially constructed variables within identity development, it is only fitting that the racial identity of African Americans be considered when examining why they do not succeed at the level of their White counterparts. 


\section{Legislation}

Since 1965, state law has mandated that all school districts enrolling over 100 twelfth grade students make available a continuation program or school to provide an alternative route to the high school diploma for youth vulnerable to academic or behavioral failure. (De Velasco, 2008, p. 1)

Prior to this, “. . . the Part-time Education (PTE) Act of 1919 required any district with fifty or more fourteen to eighteen year old students in a three mile radius to establish parttime classes for at least four hours a week ..." (Williamson, 2008, pp. 5-6). However, there was no systematic way of measuring the effectiveness of these schools. Williamson posited that state guidelines were informal with regard to the establishment of continuation school classes, which left matters such as this under the purview of local administrators. Additionally, there was no state oversight.

The Public Schools Accountability Act of 1999 authorized the creation of an educational accountability system for California public schools (CDE, 2010e). Its primary goal was to help schools improve and to measure the academic achievement of all students. This lead to the creation of the Alternative Schools Accountability Model (ASAM), that “... provided school-level accountability for schools serving highly mobile and at-risk students" (EdSource, 2008a, p. 4). Under ASAM, schools can select three indicators of progress and report on those indicators annually. Schools that fall under ASAM are able to select indicators other than standardized test scores as a measure of progress. However, according to EdSource researchers (2008a), after the inclusion of continuation schools in the NCLB accountability system, continuation schools now receive Academic Performance Index (API) scores (taken from students' performance on 
standardized tests) and evaluations of progress are now based on Adequate Yearly

Progress (AYP) goals under NCLB. Now that the accountability model has been reviewed, the topic of discussion will move into alternative education.

\section{Alternative Education}

Alternative Education as it is thought of at this time, should be defined. According to Aron (2006, cited in NCES, 2010), “. . . alternative education in its broadest sense covers all educational activities that fall outside the traditional K-12 school system ..." (p. 3). This includes charter schools, continuation schools, special programs, home schooling, General Education Development (GED) test preparation programs, and nonpublic schools. As of 2009-10, there were 95,329 alternative schools or programs of choice for Kindergarten through eighth grade and 101,951 alternative schools or programs of choice available to students in California (CDE, 2010e). Yet, because these schools fall under the ASAM model of accountability (referenced above), “. . . there is no way to compare performance across schools in this system" (De Velasco, 2008, p. 20). This is because alternative education schools held accountable under ASAM can choose which indicators they want to report to the state as measurement of success and/or progress. Moreover, as Williamson (2008) noted, continuation school “...organizational flexibility ... comes at the expense of continuation students who experience a wide range of quality and availability of resources and opportunities" (p. 13).

The term alternative education has traditionally been associated with continuation schools or special education schools (Aron, 2006, cited in NCES, 2010); however we can see from the above that the term encompasses every facet of education that occurs outside of the traditional public education system. Moreover, Carver and Lewis (2010) asserted, 
alternative schools and programs are designed to address the needs of students that typically cannot be met in regular schools and these students are typically atrisk of educational failure (as indicated by poor grades, truancy, disruptive behavior, pregnancy, or similar factors associated with temporary or permanent withdrawal from school). (p. 1)

Students serviced by alternative education schools generally look to these schools to provide collaborative services that are innovative in order to assist them with reconnecting to the education system so that they can achieve success in today's economy. However, alternative education and specifically continuation schools had a very different meaning when they first came into existence. In order to discuss continuation schools, we must be concerned with alternative education as a whole, as continuation schools are a part of the system known as alternative education.

\section{Historical Overview of Alternative Education}

Alternative education in the modern sense of the term arose during the Civil Rights movement era in the 1960s. Alternative schools were seen as options to the failure and/or lack of challenge experienced by some students in the public school system at the time. According to Raywid (1982), most alternative schools were established in response to students' needs not being met by traditional programs, and/or to respond to specific problems related to truancy and dropout rates. The different types of schools that arose catered to different populations. Raywid discussed in her review of over 1200 alternative schools nationwide the reasons behind their origination. Raywid found that those schools that served lower-class students originated to get those students to school and keep them there. Yet, other schools were not started to address this issue, but instead 
focused on increasing challenge of academia for students. In this historical review of alternative education, different types of alternative schools in addition to continuation schools will be discussed along with a brief discussion of the populations they served.

Despite the victory achieved against segregation in Brown v. Board of Education of Topeka (1954), during the late 1950s and early 1960s there was little focus on the level of equity in schooling for minority students. As Lange and Sletten (2002) stated, "the mainstream public education in the late 1950s and early 1960s was highly criticized for being racist and exclusively designed for the success of the few" (p. 3). With the government at the time emphasizing excellence, equity reentered the discussion and funding was provided to create meaningful education experiences for disadvantaged and minority students. This resulted in the creation of alternatives to the public education system. There was a split between the types of alternatives with one type of school focusing on community, while the other type focused on individual achievement.

Schools that focused on community issues, such as obtaining the right to vote for African Americans, were named Freedom Schools. According to Lange and Sletten (2002), these schools were developed as community-school models and were performed outside of the public education system in various settings, including churches and basements. These schools were ultimately designed to provide liberatory education at a high quality to minorities who had previously been exposed to inequitable and unequal treatment in the public school system, such as African-American students.

The other type of schools that arose at the time focused more on academic achievement. These schools were known as part of the Free Schools Movement. Free schools were founded on the notion that traditional public education was inhibiting many 
students from exploring their natural intellect and curiosity (Lange \& Sletten, 2002).

These schools were created to give students freedom to learn and freedom from restrictions, thus there was no required learning or set discipline, as individuals who subscribed to the doctrine of these schools believed in natural consequences. There were no tests for evaluation of learning or formalized teaching. All learning in these schools was self-determined by students. Unfortunately, these early school models were unable to sustain over a long period of time; yet the movement helped to further evolve alternative education. Raywid (1994) pointed out that despite ambiguities in these earlier models, it is apparent that alternative schools have been designed to respond to students who are not fully served in the traditional public education system. According to Lange and Sletten (2002), another lasting contribution gained out of the early days of alternative education was the notion that not all students learn best in the same educational context. Thus, these early movements in alternative education led to a reform movement within the traditional public education system that began in the latter half of the 1960s (Lange \& Sletten).

Alternative education of the previous referenced movements was used by educators in the public school system to create additional alternatives that were operated within the traditional public education system. One of the main types of alternative schools that originated in the early 1970s was Open Schools. According to Lange and Sletten (2002), these schools were characterized by parent, student, and teacher choice; there was autonomy in learning and in the pace of learning. Additionally, these schools relied on non-competitive evaluation and were student centered. Young (1990) attributed the creation of alternatives at all levels of education to Open Schools. Some notable 
types of schools within the Open Schools model, according to Young, were schools without walls, which emphasized community-based learning where individual members of the community acted as teachers of school children in these schools. Additionally there were schools within schools, which made larger schools into smaller communities; and multicultural schools, which were created to infuse the culture and ethnicity of minorities into the curriculum. The populations of the latter school were largely diverse; however, there were some that catered to specific ethnic groups. Moreover, Open Schools included Learning Centers, designed to meet students' vocational needs in a school setting, and Fundamental Schools, which arose in opposition of Free Schools and focused on going 'back to basics.' These schools contended there needed to be structure and discipline of students, hence the 'back to basics' mentality.

During this time (1970s) there was also an increase in the number of Continuation Schools, which were used to facilitate academic achievement in students who were failing in the public school system because of issues related to dropout, failing grades, and pregnancy among others. (Note: Continuation Schools have been in existence since the early 1900s and this will be discussed in subsequent pages). Young (1990) pointed out that this type of school followed the Open Schools model in that they were less competitive and more individualized. Unfortunately, many of the Open Schools were unable to sustain and as a result disappeared. In addition to this, according to Young, the 1980s in the U.S. saw a shift from progressiveness to conservatism which further moved the school system away from Open Schools. 


\section{Types of Alternative Education Programs}

Aron (2006, cited in NCES, 2010) discussed the three differing types of alternative education programs for students based on Raywid's (1994) work. Discussion of this information showed the murkiness that can be found in alternative education programs and the services they provide. Raywid posited that there were three typologies of alternative schools with goals that provide distinguishing characteristics. In type one schools, students who may need more individualization can take advantage of full-time, multiyear education options; this allows for credit recovery. Ultimately with this type of school it is the student's choice to attend. According to Raywid, these types of school models include magnet schools, charter schools, dropout-recovery programs, to name a few.

Type two schools include schools with discipline as the main focus of the school. The students who attend these types of schools are sent to the schools for specified time periods; or until students begin to show serious engagement in behavior modification practices. The curriculum at these schools generally consists of only basic courses, since placements are for shorter periods of time. According to Raywid (1994), these types of school models include last-chance schools and in-school suspension schools.

Type three schools target specific student populations who are in need of services related to social and emotional problems. Various services are offered at these schools including counseling, access to social services, and academic remediation. Yet students who attend these schools can choose not to participate.

Raywid (1994) suggested that the first type of school discussed above is the most successful and lead to more substantial student gains. Although it is important to note as 
Aron (2006, cited in NCES, 2010) stated, the aforementioned program types are often blurred as type one and type two schools may offer clinical counseling which is a type three characteristic. Because of the blurring of program types and the broad definition of what an alternative education program is, educators cannot place students appropriately into programs that will effectively meet their needs. As Aron stated, there needs to be a systematic way of characterizing these programs.

\section{Research and Alternative Education Programs}

Vadeboncoeur (2009) completed an ethnographic study of three programs in the U.S., Australia, and Canada to look at the benefits of attending alternative education programs as well as the potential negatives. She found that youth who attended these programs were either referred by teachers or counselors or were at-risk of dropping out or disengaging. The programs were of benefit in that they mediated knowledge and knowing, identity and difference, and social and political answerability through relationships and discursive practices. However, Vadeboncoeur found that despite this, these programs are inherently a contradiction and they are a result of the failure on the part of traditional education. The author found through her research that there was a common message present, "schooling functions to displace students who are deemed different. It is a system that neither encourages student empowerment nor tolerates any behavior that agitates the status quo" (Dei, Mazzuca, McIssac, and Zine 1997, p. 199, cited in Vadeboncouer, p. 294). These findings reflect heavily on the need for education to employ the use of critical pedagogy in the classroom in order to transform the teacher and the student. 
Kim (2006) looked at the voices within alternative schools and how the current education system is contradictory. Over a four-month period collecting data through narrative inquiry and employing methods of participant as observer, she attempted to understand the lived experiences of teachers and students. She found that all participants saw something different and spoke to the need for there to be a unified voice made up of many voices relating to alternative education. The significance is clear; recall Matsuda (1995) suggested that those individuals who have experienced discrimination speak with a special voice to which we should listen. In essence, voice allows students to use their own experiences in order to produce knowledge out of the curriculum they are given; where they are allowed to connect the material to themselves and their community.

Using critical theory, Kim and Taylor (2008) looked at how the cycle of educational inequality continues to lead to the disenfranchisement of minority students in alternative education, specifically continuation education. The school site they chose was located in a Midwestern location and the student body was comprised of $60 \%$ minority students and $70 \%$ of those students received free and/or reduced lunch. The school serviced 40 students from grades 9 through 11 who were credit deficient for graduation and experiencing academic challenges due to court involvement, gang activity, theft, or vandalism. They found that although the school was deemed to be successful by school administrators and provided a positive and nurturing environment, the school seemed to lack the systemic support that would break the cycle of educational inequality. Kim and Taylor found that students were only offered a basic curriculum that helped them recover credits, however did nothing to build student integrity, or engage them in meaningful learning related to critical thinking. Additionally, they found that students often had a 
negative stigma towards being placed in any type of alternative education, which later subsided after having been present in the school for a period of time for some students, but not all.

Similar findings existed in a research study conducted by Wiest, Wong, and Kreil (1998) related to student self-worth and academic achievement. The researchers looked at 251 juniors and seniors who were either in "low-track," Advanced Placement (AP), or "college prep," and 93 of whom were enrolled in the continuation school; 54 were identified as learning disabled. Wiest et al. claimed they reviewed a diverse population, but sampling was not random and administrators chose students and the breakdown is as follows $42 \%$ white, $29 \%$ Latino, 9\% Asian, 4\% African American, and 16\% other as Figure 1 shows.

The researchers found that teacher warmth was an important predictor of achievement and the promotion of community. Wiest et al. (1998) found that it was important to build upon the students' ability to feel autonomous and competent, yet this is often difficult in the traditional public education system for minority students who unfortunately come from schools that heavily rely upon the banking model of education. Lastly, they found that placement in continuation schools had a significant negative association and stigma, which questions the notion that continuation schools are good for students. However, with the current standards-based teaching occurring in schools along with the notion that teachers are in fact becoming technicians, the warmth factor or student autonomy is not always present; yet in this researcher's opinion, is desperately needed. 


\section{Historical Overview of Continuation Schools}

Despite the disappearance of many of the Open Schools, the Continuation School started to thrive again because of the growing number of alternatives geared toward disruptive and/or failing students (Young, 1990).

To provide a brief history of continuation schools let us begin with the work of Jones (1907). As early as the 1900s, the term continuation school existed. According to Jones-who studied continuation school models from other countries, including Germany and England—continuation schools were there to meet the needs of individuals who were working and continuing their education and training. Jones further noted the lack of information present in research data at schools related to continuation schools, as they were defined at that time. According to Williamson (2008), public schools had failed to meet industrial and societal needs, and continuation schools became an alternative tool to meet these needs for young workers and recent immigrants in need of assimilation. According to Kelly (1993), “... continuation schools took place largely in compulsory part-time schools designed to provide young workers, aged fourteen to eighteen years, with four to eight hours per week of schooling aimed at increasing their 'civic or vocational intelligence"” (p. 37). Additionally, Kelly pointed out that a common opinion of professionals in the early 20th century was that male students in particular were in need of vocational focus because they "... were vulnerable to recruitment into crime" (p. 40). Therefore, the continuation school in the 1920s alone dealt with the young person in a man-to-man fashion at the most pivotal point of his life (Mayman, 1933, p. 198 cited by Kelly, 1993, p. 40). According to Williamson, "not only were part-time schools to provide 'social guardianship' for impressionable students, for 'from this 
group'... most criminals are recruited..." but "the needs of the next generation must be considered in the education plans of today" (p. 7). Continuation schools continued to grow, and as Williamson noted, the number of students attending a continuation school more than tripled from 6,965 students to 22,631 students.

Interestingly, Kelly (1993) stated that continuation schools continue to flourish as a viable option for youth because of their "chameleon like qualities" (p. 34).

Continuation schools have been presented many times over as the state-of-the-art solution to the community's latest concerns about teenagers (Kelly). According to Williamson (2008), relying on the work of Kelley, Hwang (2003), Warren (2007), and Ruiz-DeVelasco (2008),

alternative education research to date describes three types of continuation programs that reflect the continuation system's ability to take on different local roles: 1) safety net, 2) safety valve-where '. . rebels and failures are put into a separate institution that ... aims to reconnect these students to education enterprise' ... (Kelly, p. 31)

—and 3) cooling out programs" (Williamson, p. 2). Or continuation schools can be classified as: 1) student-centered, 2) student-reform, and 3) dumping-ground programs. According to Williamson, in both types of programs listed previously, type one are programs that generally provide an abundance of resources for students to achieve academic success; type two programs can be viewed as programs that separate disengaged students out of traditional public education; and type three programs act as a hiding place for failing students. 


\section{Continuation Schools and This Study}

Continuation schools, where research was conducted for this study, offer alternatives to the traditional public education system for students. According to the California Department of Education (CDE, 2010b), continuation high schools focus on school-to-career education, individualized instructional strategies, intensive guidance and counseling, and flexible school schedules to meet student needs. These schools serve students aged 16 years of age or older who lack sufficient school credits, have not graduated from high school, are not exempt from compulsory school attendance, are deemed at-risk of not completing their schooling, and are at-risk of not graduating. According to the CDE website, "in October 2008, there were 525 continuation high schools reporting an enrollment of 70,937” (2010c, n.p.). Possible reasons for students lacking sufficient credits for graduation have been previously discussed in this chapter and will be further elaborated upon. It is evident from research that students need alternatives to complete the requirements for a high school diploma or they will be faced with financial difficulties and may not be able to become contributing democratic citizens without completing high school with a diploma.

Specifically, in the state of California there are four main types of alternative education programs. "State law requires school districts and county offices in California to provide alternatives to the comprehensive high school for "students vulnerable to academic or behavioral failure" (EdSource, 2008a, p. 1). The four types of schools are continuation schools_-generally these schools help students who are credit deficient; community day schools — serve students with serious discipline and behavioral issues; 
county-run community schools_-for adjudicated or expelled youth; and independent study programs—operated by school districts as educational options (EdSource, 2008a).

Students who are at-risk often need services from a continuation school and are mainly students of color who live in impoverished/low socio-economic status (SES) areas. Continuation school attendees are more likely to be Hispanic, African American, and English Learners with 55\% of Hispanics, $11 \%$ of African Americans, and $21 \%$ of English Language Learners enrolled in continuation schools compared with $42 \%, 8 \%$, and $14 \%$ respectively of the total 11 th grade enrollment population statewide (EdSource, 2008a). In addition to being at-risk for requiring services from a continuation school based on being classified as an ethnic minority, "continuation students are more likely than comprehensive school students to be in foster care or living with a relative other than a parent" (EdSource, 2008a, p. 3). Kim and Taylor (2008) related educational failure to factors such as “. . . poverty, minority status, or family characteristics ..." (p. 208). Unfortunately, Kim and Taylor found that the system largely engages in deficit thinking and used Valencia \& Solórzano (1997) to discuss how the system often blames low-SES students for their own failure in schools and forgets to look at inequities relating to school funding, curriculum differentiation, low teacher quality, poverty, ethnic minority status, and family characteristics, which ultimately help to maintain the status quo. According to Katz (1987) as cited by Fine (1991), "the problem with American schools has been not their lack of purpose but their continued commitment to purposes rooted in social inequality and its attendant culture" (p. 24). This thought is expanded upon by Aronowitz (2004) when he stated that some of the same educational analysts favor a curriculum that stresses critical thinking for a small number of students in a 
restricted number of sites is consistent with the dominant trends of schooling since the turn of the 21 st century. It is this researcher's opinion that a system-wide failure to recognize factors that hinder the success of ethnic minority students in traditional public education causes these students to be pushed out of traditional education and inadvertently into alternative education.

According to Fine (1991), despite the progressive legislation resulting from court cases and laws that have been enacted over the past three decades, such as Brown v. Board of Education (1954) and later Brown II (1955), Title IX of the Educational amendments of 1974 related to gender, Lau v. Nichols (1974), PARC v. Commonwealth (1972) and Mills v. Board of Education (1972) related to rights for disabled students, there are still doubts that linger about what progress has actually been made. Further, according to Fine, dropping out of high school in some schools is in fact a shared tradition for schools that are low income, urban, and often "of color." According to the CDE (2010a), for the 2008-09 school year there were 13,808 African-American students that dropped out of school between 7 th and 12th grade. Specifically focusing on grades 9 through 12, there were 12,508 African-American students that dropped out during the aforementioned school year (CDE, 2010a); bringing the derived 4-year dropout rate to $29 \%$, the highest in all ethnic categories listed on the CDE website. Of those 12,508 students that dropped out during the 2008-09 school year, only 3,414 reenrolled in grades 9 through 12. Fine suggested that because low-income students disproportionately attend dropout-prone schools, and since they drop out more often than relatively elite peers, it is important to document the economic impact that leads to social inequity. According to Fine with regard to income, “. . . the high school diploma yields, for whites, 
men and upper-middle-class students, consistently more per additional year of education than it does for African Americans and Latinos, women, and working-class or lowincome students, respectively" (p. 23).

According to Aron (2006, cited in NCES, 2010), we see a clear connection between the education of the individual and their earning potential. In 1971, students who dropped out of high school earned the equivalent of $\$ 35,000$ (in 2002 dollars), whereas those individuals now would earn less than $\$ 24,000$. Additionally, dropouts are much more likely than their peers who graduate to be unemployed, poor, incarcerated, unhealthy, and single parents with children who will drop out of high school themselves (Bridgeland, DiIulio, \& Morision, 2006, cited by Perez \& Johnson, 2008). The implications here are clear, without successful navigation through the education system, individuals can expect to live a life of poverty that thereby perpetuates the status quo, where these individuals will continue to be marginalized and oppressed by those in power. However, to understand why students must look to alternative education programs, we must look at how these students leave the traditional public education system.

Minority students can be pushed out of traditional public education when they have no voice within the curriculum. It is not a one-time incident that results in them leaving schools; instead, it is a gradual progression where they are exposed to curriculum that considers "good reading" as Fine (1991) stated, that is signified by Whiteness and usually the maleness of the authors. Without educators who are able to recognize the property functions of Whiteness, Ladson-Billings and Tate (1995) showed as the ability to The Rights of Disposition; The Rights to Use and Enjoyment; Reputation and Status 
Property; The Absolute Right to Exclude, students will continue to find themselves stuck within a curriculum that fails to mirror their lives. These property functions of Whiteness are important because they uphold what hooks (1994) calls bourgeois values, which are often foreign to minority students. In education, bourgeois values are a set of unwritten rules that are created by those in power and must be upheld by students if they are to fit in positively in the classroom environment. Teachers who fail to discuss these values in fact perpetuate the cycle of under-serving students from working-class/poor backgrounds because these students come to school and find that they are ill-equipped to meet the unwritten requirements of behavior necessary to be successful in the current education system. Students who are informed of these issues much later in life can experience a much more difficult journey through the education system. Those who are able to adapt often lose the possibility of constructive dialogue with the teacher because their voice is silenced as they attempt to navigate through the education system, ultimately resulting in the undermining of academic achievement. According to Anderson (n.d.) cited by hooks (1994), silencing is “. . . the most oppressive aspect of middle-class life . .." and "it thrives upon people keeping their mouths shut, unless they are actually endorsing whatever powers exist" (p. 180). It is the silencing effect that prevents students from fully participating in the academic process and experiencing the full richness of the process. This is done by teachers controlling what is said in the classroom and what is not, thereby perpetuating the status quo. When educators are able to do the opposite and allow students to be truly free in their expression of knowledge and ideas, only then will students and educators alike be able to truly engage in learning. 
Thus, when education is the practice of freedom, students are not the only ones who are asked to share, to confess. Engaged pedagogy does not seek simply to empower students. Any classroom that employs a holistic model of learning will also be a place where teachers grow, and are empowered by the process" (hooks, 1994, p. 21).

Until such time, students, and specifically minority students, in light of research presented throughout this chapter, will continue to require alternatives to the traditional public education system.

To summarize, once at-risk students have been pushed out of traditional public education, it is not uncommon for students to attend a continuation school in order to receive any type of emancipatory education that will assist them in succeeding in society today. However, the continuation school that is in place today does not always provide students with the necessary content or direction that they will need to be successful.

\section{What Might This Mean?}

From the above-referenced research articles, it is clear that we need to ensure that students who are forced into some type of alternative education programs, specifically continuation schools for the purpose of this research study, have the ability to use their voice in order to incorporate lived experiences in a manner that facilitates the construction of knowledge and therefore power. Referring back to Freire (1970), knowledge or education is a means of liberation to change your life circumstance as well as others. The conflict here that needs to be addressed is two-fold, in that we must begin to address the systemic inequities that occur within the current education system that causes students to drop out of school. Additionally, we must address the disparities in the 
alternative education programs that these students find themselves entering which are supposed to assist with furthering their education in order to be successful within society. Further, the element of critical thinking through critical pedagogy must be employed if students are ever going to move out from under the thumb of the hegemonic control mechanisms that exist within our society.

According to Aron (2006, cited in NCES, 2010) there are few scientifically based, rigorous evaluations establishing what alternative education program components lead to various positive outcomes for youth. Additionally, according to the EdSource report (2008a), the researchers found it clear that even the most basic data about continuation schools including their enrollment figures are uncertain. As the EdSource researchers further stated, the uncertainty was in large part due to the mobility of the student population served by continuation schools. Aron called attention to a list of key attributes that a program should employ to ensure success for its students. That list includes quality academic instruction, instructional staff, professional development, size, facility, relationships/building a sense of community, leadership/governance/ administration/oversight, student supports, and other contributing factors (which may include the integration of special education services and ELL programs along with a stable revenue stream). This research study focused on students' perceptions of their continuation school experiences related to their teachers (past and present), guidance received, friendships or relationships with friends within the school and outside of the school, parent or caregiver involvement (current and desired), and overall feelings about their continuation school. This information was helpful in determining if African- 
American students expressed more positive than negative perceptions of their continuation school experience.

\section{Summary}

In this study giving African-American students voice was explored related to their perceptions of their experiences at two public continuation high schools. The expectation was that the African-American students would report increased incidences of lower levels of parental involvement, and higher incidences of discipline issues. Additionally, this research study examined the students' thoughts about successes of their continuation school education programs and/or failures. Further, this study examined whether the needs of students were being met through their perceptions of their experiences at their continuation schools. In summation, in the case Tyler Independent School District et al. v. Doe, Guardian et al. (1982) stated, as cited by Fine (1991), Public education has a pivotal role in maintaining the fabric of our society and in sustaining our political and cultural heritage; the deprivation of education takes an inestimable toll on the social, economic, intellectual and psychological well being of the individuals and poses an obstacle to individual achievement ( pp. 202-203). (Fine, p. 19)

In Chapter Three, the methodology used to study the phenomena of student perceptions about their placement in continuation schools and their future success after school will be expanded upon. 


\section{CHAPTER THREE \\ METHODOLOGY}

This chapter describes the method that was used to conduct research for this study. Specifically, it describes the participants and their selection, the measures that were employed, and the procedures for data collection and analysis.

\section{Research Question}

1. What are the experiences of African-American students who attend continuation schools related to self-esteem, education-previous, current, and post continuation school placement — and does this affect their outlook on their futures?

\section{Delimitations}

1. This study will not examine the effectiveness of one alternative education setting over another; for example, the effectiveness of a continuation school versus that of a charter school.

2. Generalizability of the research study is not known. Because the phenomena exists at the research sites for this study, does not mean that it will be able to be duplicated at other sites with similar results.

3. Discussion of the perceptions of all minority populations will not be reviewed; only that of African-American students. Again, generalizability of results to other minority populations will not be researched. 


\section{Variables}

Dependent variable. Perceptions of African-American students' experiences in continuation schools based on survey questions.

\section{Independent Variables:}

1. Gender

2. Attendance at a traditional continuation high school; attendance at a nontraditional continuation high school

3. Reasons for attending a continuation school (credit recovery; discipline issues; both)

4. Living Situation (w/parents; w/a relative; w/a foster parent; group home; on own)

5. Grade enrolled in current continuation school (ninth, tenth, eleventh, twelfth)

6. Type of school enrolled prior to attending continuation school (traditional public high school; non-public; continuation school; other alternative education setting)

\section{Hypotheses}

1. Students with discipline issues will rate their continuation high school experiences more positively than negatively.

2. Students with reportedly low parent/caregiver involvement will rate their continuation high school experiences more positively than negatively.

3. Student responses to survey questions will be more positive than negative as they rate their perceptions of their continuation school teachers.

4. Students in a non-traditional continuation high school will respond more positively than negatively about their continuation high school experiences when compared to students in a traditional continuation high school. 


\section{Description}

A quantitative cross-sectional survey research approach was used to conduct this research study. A quantitative approach includes "the collection and analysis of numerical data to describe, explain, predict, or control phenomena of interest" (Gay, Mills, Airasian, 2009, p. 7). Survey research “. . . involves collecting numerical data to ... answer questions about the current status of the subject of study" (Gay et al., p. 7) and “. . . can be used to gather information about a group's beliefs, attitudes, behaviors, and demographic composition" (Gay et al., p. 175). The quantitative paradigm is often referred to as the positivistic research paradigm. A one-way Analysis of Variance (ANOVA) was used to analyze data collected (discussed later in this chapter). Further it was determined that a survey would provide the most efficient way to collect and analyze the data.

As mentioned previously, this study was quantitative in nature and involved this researcher surveying African-American students attending two different continuation high schools (one traditional [A] and one non-traditional [B]). Continuation High School statistics obtained directly from the school sites for this study are shown in Tables 1 and 2. All tables can be found after the Reference section of this paper.

The survey was conducted to highlight students' perceptions of their continuation school experiences in relation to different independent variables. These variables included increased gender, reporting of discipline issues, little parent involvement, type of school enrolled in prior to attending the continuation school, living situation, and type of continuation school attended. Participants chose their answers based on a 5-point 
Likert scale ranging from strongly agree to strongly disagree; there were two open-ended questions where participants were able to expand upon their personal experiences.

\section{Selection of Participants}

Purposive sampling was employed to select the participants of the study. This strategy was employed because participants were "believed to be representative of a given population ..." (Gay et al., 2009, p. 135) related to the success of AfricanAmerican students in continuation schools. Participants included African-American students attending two continuation high schools (one traditional and one non-traditional)

in California's _ with the chosen schools' distance being approximately miles east of Los Angeles, California. Students were selected solely on the basis of their race/ethnicity of being African American, regardless of reasons for attending a continuation school (i.e. poor grades, credit deficiency, pregnancy, or disciplinary issues). The breakdown of gender is as follows: 48 males; 14 females. The total number of ninth through twelfth grade student participants was 62 as shown in Table 3 (Note: School A has grade levels of 10-12; School B has grade levels of 9-12).

\section{Measures}

The single measure that was used in this study was a survey (see Appendix A) containing 24 questions given out to students at their school sites by this researcher. Twenty-two questions were answered on a 5-point Likert scale from strongly agree to strongly disagree, and two open-ended questions gave students the opportunity to write about their personal experiences. The questions for the survey were designed to illicit answers related to the perceptions of African-American students about their success at a 
continuation school, current and future. This researcher used Survey Monkey to create the survey and printed copies to take to the sites. Pencils were provided to students.

\section{Data Collection}

The district of Continuation High School A forwarded via email demographic information of minority students including testing data to this researcher. Included in that data were CST scores, ethnicity of students, and California High School Exit Exam (CAHSEE) test results. This test data was not analyzed for the purpose of this research study, except to gather the number of African-American students present at the school site. The school administrator of Continuation High School B forwarded via U.S. Postal Service demographic information of all students to this researcher. This information was summarized in Tables 1 and 2.

Data was collected from Continuation High School A and B in the form of surveys over a five-week period. This researcher visited Continuation High School A on February 15, 2011 and Continuation High School B on January 20, 2011 to conduct the survey.

School personnel (the principal and secretary) were present at Continuation High School A with this researcher during survey completion. Both the principal and secretary assisted in setting up the classroom where students completed the surveys. School personnel assisted with collecting surveys from students as they completed the surveys. Students were informed of the purpose of the study by this researcher and that their participation was completely voluntary. Surveys were conducted on an anonymous basis as no names were given or written on the surveys by students, staff, or this researcher. The survey took approximately 20 minutes for students to complete. Of the 59 African- 
American students enrolled in the school, 18 were available to complete the survey.

Students who were absent on the date the survey was administered, were then contacted by school personnel and completed the survey on March 2, 2011. This researcher returned to the Continuation High School A to collect the completed surveys; bringing the total number of participants at Continuation School A to 25 African-American students.

School personnel (principal and a staff member) were present at Continuation High School B with this researcher and assisted in handing out and collecting surveys from students. Of the 39 African-American students enrolled in the school, 37 were available to participate in the survey. Students were informed of the purpose of the study by this researcher and that their participation was completely voluntary. Surveys were conducted on an anonymous basis as no names were given or written on the surveys by students, staff, or this researcher. The administration and collection of the survey by school personnel took approximately 20 minutes.

\section{Data Analysis}

The quantitative method used to examine the data for statistical significance between dependent and independent variables was a One-Way ANOVA. "ANOVA has the advantage that it can be used to analyze situations in which there are several independent variables" (Field, 2005, p. 309). Additionally, an ANOVA was found to be an appropriate test as this researcher wanted to compare "... the scores of three or more independent groups (present within the independent variables) on a scale variable ..." (Connolly, 2007, p. 209). The ANOVA test was also performed with the Games-Howell post hoc test to account for any difference in the sample populations and also differences 
in sample group variance that may not have been known. During the ANOVA analysis, some question variables did not meet Levene's test for Homogeneity of Variance; these variables are identified in subsequent tables by an (*). A Kruskal-Wallis test was performed on question variables that did not meet Levene's test and results are reported in subsequent pages. The Kruskal-Wallis test can be used when comparing three or more categories of the nominal variable when certain assumptions are violated; as in the case of failing to meet Homogeneity of Variance.

Prior to performing an ANOVA, factor analysis was employed to determine groupings of variables to be examined. Factor analysis is ". . . a technique for identifying groups or clusters of variables" (Field, 2005, p. 619). Field further explicated that "the existence of clusters of large correlation coefficients ... suggests that the variables could actually be measuring aspects of underlying elements" (p. 620). The data examined for this research study was grouped into two categories based on the results of the Pattern Matrix resulting from the factor analysis. Using a principal component analysis type of factor analysis, the total variance among the variables was examined. Factor analysis tested for multicollinearity to determine if variables were correlated fairly well, however not perfectly and not at all. After review of the correlation matrix, it was determined that multicollinearity was not a problem, thus no variables required elimination. Lastly, the KMO Bartlett's test revealed the data set was a good fit for factor analysis.

\section{Summary}

The method and design of this research study was a quantitative cross-sectional survey approach. Participants included 62 African-American students from two different continuation high schools (one traditional model and one non-traditional model). Since 
this survey was designed by this researcher for this study, reliability and validity were not tested due to this being the first administration of this survey. At both sites, it took approximately 20 minutes for surveys to be administered and collected. The analysis of the data and results will be expanded upon in Chapter Four. 


\section{CHAPTER FOUR \\ FINDINGS/RESULTS}

\section{Introduction}

This chapter reported the findings extracted from the research data resulting from the survey of 62 African-American students attending two different continuation high schools (one traditional model and one non-traditional model). As discussed in Chapter Three, the student participant respondents included 37 of 39 African-American students (response rate of 94\%) at the non-traditional continuation school, and 25 of 59 AfricanAmerican students (response rate of $42 \%$ ) at the traditional continuation high school. As noted in Chapter One, the purpose of this study was to document the experiences of African-American students in continuation school. The survey tool consisted of 24 questions total, with 22, 5-point Likert scale based questions (ranging from strongly agree to strongly disagree) and two open-ended questions (see Appendix A for student survey). Students' written responses to the open-ended questions will be listed in Appendix F for review. No analysis of the open-ended responses was conducted for the purpose of this study. The Likert-scale based questions were coded into SPSS for statistical analysis and a factor analysis of the survey was completed.

Based upon the results of the factor analysis of the survey questions, certain variables (questions $=\mathrm{Q}$ ) loaded onto one of two factors and created group trends (see Table 4 for factor loading information). Those groups were then tested against the independent variables for effect. The results will be reported in subsequent pages. It should be noted that Gender as an independent variable was found to have no statistical 
significance in affect on any of the variables and therefore will not be reported on in this chapter.

\section{Independent Variables [I.V.]}

1. Gender

2. Reasons for attending a continuation school (credit recovery; discipline issues; both) [I.V.1]

3. Type of school enrolled prior to attending continuation school (traditional public high school; non-public; continuation school; other alternative education setting) [I.V.2]

4. Living Situation (w/parents; w/a relative; w/a foster parent; group home; on own) [I.V.3]

5. Grade enrolled in current continuation school (ninth, tenth, eleventh, twelfth) [I.V.4]

6. Attendance at a traditional continuation high school; attendance at a nontraditional continuation high school [I.V.5]

\section{Group One Findings}

Group one included the following variables: Q9 (your parents/caregiver are very involved in your education); Q10 (you would like your parents/caregiver to be more involved in your current education); Q11 (you believe your education in this continuation school is important); Q16 (you have many friends within this continuation school); Q17 (you have many friends outside of this school); Q18 (you put in more time doing your school work at this continuation school than you did at your previous school); Q19 (you believe you will be well prepared for college or work after you graduate from 
high school); and Q22 (you feel that you receive more guidance at this school compared to your previous school), which seemed to relate to students' perceptions of being prepared for education including, parent involvement in the students' education. It should be noted that question variables Q18 (you put in more time doing schoolwork at this continuation school than you did at your previous school) and Q11 (you believe your education in this continuation school is important) loaded onto both factor groups, however were included with group one because they seemed to fit better with the trend of group one. The number of participants, mean, standard deviation, ANOVA, and significance of the responses for I.V.1 (reason for attending continuation school) are shown in Table 5. As aforementioned, some question variables did not meet Levene's test for Homogeneity of Variance when analyzed with different independent variables (shown in tables with [*]). Therefore, Welch's F statistic is reported for those variables. The Welch F statistic is reported when Levene's test is violated during the ANOVA.

For I.V.1 (reason for attending a continuation school), there was no statistical significance present in the ANOVA. The Games-Howell post hoc test was also performed with the ANOVA to account for the difference in samples (school A vs. school B). Again, no statistical significance was observed between I.V.1 and the dependent variables. Question variable Q18 (you put in more time doing your schoolwork at this continuation school than you did at your previous school) failed to meet Levene's test for Homogeneity of Variance. Therefore a Kruskal-Wallis test was performed and no statistical significance was found. The results are reported in Table 6. It can be concluded from the analysis overall that there was no statistical significance between I.V.1 and any of the dependent question variables. 
For I.V.2 (previous school attended), the mean, standard deviation, confidence intervals and ANOVA results between group one's dependent question variables and I.V.2 are reported in Table 7.

For I.V.2 (previous school enrolled), after review of the ANOVA and GamesHowell statistical tests, question variables Q10 (you would like your parents/caregiver to be more involved in your current education), Q16 (you have many friends within this school), and Q22 (you feel that you receive more guidance at this school compared to your previous school) did not have any statistically significant findings to report as shown in Table 7. The following question variables did not show any statistically significant findings through the ANOVA, however significance was found after analysis of the Games-Howell post hoc test results.

Q9 (your parents/caregiver are very involved in your education) showed a mean difference $(.810)$ between attending a traditional public school compared to attending other alternative setting was statistically significant at $p<.05$ with a $95 \%$ CI $(.37,1.25)$. $r=.19$ indicates a very small effect of previous school type attended on students' perception of their parent/caregivers involvement in their education.

Q11 (you believe your education in this continuation school is important) showed a mean difference (.595) significant at $p<.05$ between attending a traditional public school and another alternative setting with a 95\% CI $(.28, .91)$. Also significant at $p<$ .05 in Q11 was the mean difference (.833) between attending a continuation school and another alternative setting with a $95 \% \mathrm{CI}(.21,1.46) . r=.22$ indicates a very small effect of previous school type attended on their belief about their education in this continuation school being important. 
Q17 (you have many friends outside of this school) showed no statistical significance from the one-way ANOVA, F(3, 58) $=1.07, \mathrm{MSE}=.690, \mathrm{p}=.37$. Additionally, there were no statistically significant results to report from the GamesHowell statistical test. However, this question variable did violate Levene's test for Homogeneity of Variance with $\mathrm{p}<.05$. A Kruskal-Wallis test was performed and no statistical significance was observed (see Table 8) in the results between question variable Q17 (you have many friends outside of this school) and I.V.2.

Q18 (you put in more time doing your school work at this continuation school than you did at your previous school) showed a mean difference (.905) between attending a traditional public school and another alternative setting with a 95\% CI (.41, 1.40). There was also a mean difference (1.250) present between attending a continuation school and another alternative setting with a $95 \%$ CI $(.26,2.24) . r=.24$ indicates a very small effect of previous school type attended on students' perceptions about putting in more time doing their school work at this continuation school which is in line with the lack of statistical significance found.

Q19 (you believe you will be well prepared for college or work after you graduate from high school) showed a mean difference (.833) significant at $p<.05$ between attending a traditional public school and another alternative education setting 95\% CI (.51, 1.16). Additionally, there was a mean difference (1.000) significant at $p<.05$ present between attending a continuation school and another alternative setting with a $95 \%$ CI $(.09,1.91) . \quad r=.27$ indicates a small effect between school type attended and you believe you will be well prepared for college or work after you graduate from high school. The lack of effect is expected as there was only a small statistical significance 
found. Based upon the finding listed above it can be concluded for this analysis of the independent variable and the question variables that despite the presence of some statistical significance through the Games-Howell post hoc test, there was very little size effect present between I.V.2 (previous school type attended) and dependent question variables.

For I.V.3 (living situation), statistical analysis of effect on the dependent variables using an ANOVA and Games-Howell post hoc test yielded statistically significant results between Q16 (you have many friends within this school), Q19 (you believe you will be well prepared for college or work after you graduate from high school) and the independent variable. See summary of the mean, standard deviation, confidence intervals ANOVA, and statistical significance in Table 9.

Q16 (you have many friends within this school), as referenced in Table 9, had results of the one-way ANOVA, $F(4,56)=3.42, M S E=4.05, p=.01$, statistically significant at $p<.05$. This demonstrated difference between the two groups as would be expected; indicating that your perception of how many friends you have is dependent upon your living situation. When attempting to compare the mean difference between the groups, there was no significance found with the Games-Howell test. $r=.44$ indicated a moderate effect of living situation on students' perceptions of having friends within the continuation school.

Q10 (you would like your parents/caregiver to be more involved in your education) showed no statistical significance through the one-way ANOVA, $F(4,56)=$ 2.49, $M S E=2.60, p=.054$, as shown in Table 9. Yet, there was significance found when the Games-Howell test was performed. There was a mean difference (1.119) significant 
at $p<.05$ between living with a parent and living on your own with a $95 \% \mathrm{CI}(.75,1.52)$. However, this variable when tested with I.V.3 violated Levene's test for Homogeneity of Variance and a Kruskal-Wallis test was performed. The results of those tests showed that no statistical significance in I.V.3 having an effect upon question variable Q10 (you would like your parents/caregiver to be more involved in your current education) [see Table 10]. $r=.39$ indicates a small effect for I.V.3 (living situation) on question variable Q10 (you would like your parents/caregiver to be more involved in your current education), which was expected by the lack of statistical significance.

Q19 (you believe you will be well prepared for work/college after you graduate from high school) referenced in Table 9 had results of the one-way ANOVA, $F(4,56)$ $=1.78, M S E=1.17, p=.15$, which demonstrated no statistical significance. However, review of the Games-Howell post hoc test showed a mean difference (.762) significant at $p<.05$ between living with a parent and living on your own with $95 \% \mathrm{CI}(.43,1.10)$. Yet, this question variable when analyzed against I.V.3 (living situation) did not meet Levene's test for Homogeneity of Variance and a Kruskal-Wallis test was performed. This test showed no statistical significance between this variable and I.V.3 (see Table 11). Therefore it can be concluded that I.V.3 (living situation) did not have an effect upon students' beliefs about being prepared for college or work after they graduate from high school; further expressed by $r=.33$ (small effect).

Q9 (your parent/caregiver are very involved in your education), Q10 (you would like your parent/caregiver to be more involved in your current education), Q11 (you believe your education in this continuation school is important), Q17 (you have many friends outside of this school), and Q18 (you put in more time doing your school work at 
this continuation school than you did at your previous school) showed no significance through the one-way ANOVA (reference Table 9) nor did these variables show any significance in the Games-Howell test. The variables did violate the assumption of equality of variances evidenced through Levene's Test of Homogeneity of Variances when analyzed with I.V.3 (living situation). Each variable had a significance level of $p<.05$. As a result, this researcher performed a Kruskal-Wallis test and the results showed no statistical significance between the above question variables and I.V.3 (shown in Table 12).

Lastly, Q22 (you feel that you receive more guidance at this school compared to your previous school), showed no statistical significance from the ANOVA or the Games-Howell Test. Therefore, it was concluded that living situation had no impact on students perceptions of receiving more guidance at the continuation school compared to their previous school.

For I.V.4 (current grade enrolled) there was no statistical significance found after the ANOVA; however there was significance found when the Games-Howell test was performed. Table 13 provides a summary of the mean, standard deviation, confidence intervals ANOVA, and statistical significance.

For Q9 (your parents/caregiver are very involved in your education), the results of the one-way ANOVA, $F(3,57)=1.43, M S E=2.032, p=.15$, showed no statistical significance between groups. Yet the Games-Howell test showed a mean difference (1.154) between tenth graders and ninth graders significant at $p<.05$. Also, between eleventh graders and ninth graders there was a mean difference (.783) present with significance at $p<.05$. Lastly, there was a mean difference (.722) between twelfth 
graders and ninth graders significant at $p<.05$. However, this question variable failed Levene's test for Homogeneity of Variance at $p<.05$. A Kruskal-Wallis test was performed and there was no statistical significance found (see Table 14). Therefore, it can be concluded that I.V.4 (current grade enrolled) did not have any statistically significant effect on students' perceptions related to beliefs about parent/caregiver involvement; further evidenced by $r=.29$ (very small effect size).

For Q19 (you believe you will be well prepared for college or work after you graduate from high school), the results of the one-way ANOVA, $F(3,57)=1.90, M S E=$ $1.26, p=.14$ (Table 13), showed that there was no statistical significance between groups. However, the Games-Howell test showed a mean difference (.683) significant at $p<.05$ between eleventh graders and ninth graders. Additionally, there was a mean difference (.857) significant at $p<.05$ between twelfth graders and ninth graders. This indicates that I.V.4 (current grade enrolled) did have an effect on question variable Q19 (you believe you will be well prepared for college or work after you graduate from high school). Yet, $r=.30$ indicated a very small effect related to students' current grade level upon their perception of being well prepared for college or work after they graduate from high school.

Lastly, with regard to I.V.4 (current grade enrolled), question variable Q11 (you believe your education in this continuation school is important), Q16 (you have many friends within this school), Q18 (you put in more time doing your schoolwork at this continuation school than you did at your previous school), and Q22 (you feel that you receive more guidance at this school compared to your previous school), showed no statistical significance from the ANOVA or the Games-Howell test (Table 13). 
Additionally, these question variables did not meet Levene's test for Homogeneity of Variance. A Kruskal-Wallis test was performed for each question variable in relation to I.V.4 (current grade enrolled) and no statistical significance was observed (see results in Table 15).

With regard to I.V.5 (type of continuation school attended), a summary of the mean, standard deviation, CI, ANOVA, and significance between group one's dependent question variables and I.V.5 is presented in Table 16.

I.V.5 (type of continuation school attended) yielded interesting results in regard to statistical significance between it and Q19 (you believe you will be well prepared for college or work after you graduate from high school). The one-way ANOVA showed $F(1,60)=7.24, M S E=.042, p=.01$ statistically significant at $p<.05$. The inference can be made students' beliefs about being well prepared for college or work after graduation from high school is dependent upon the type of continuation high school they attend (non-traditional or traditional). When looking at the mean rank, it appears that students in the traditional school $(M \operatorname{rank}=37.76)$ had a more positive perception of Q19 (you believe you will be well prepared for college or work after you graduate from high school) than students in the non-traditional school $(M \operatorname{rank}=27.27)$. Although, based on the Likert-scale responses, both groups of students either strongly agreed or agreed with Q19. This can be seen in Figures 14 and 15 (Appendix F). $r=.33$ suggested that the effect size of I.V.5 (type of continuation school attended) upon question variable Q19 (you believe you will be well prepared for college or work after you graduate from high school) was small. It is important to note that a Games-Howell test could not be performed on this data set because there were only two means to compare and that 
particular test can only be performed when there are three or more means to compare (Field, 2005). Additionally, there were no statistically significant findings to report related to I.V.5 affecting question variables Q9 (your parents/caregiver are very involved in your education), Q10 (you would like your parents/caregiver to be more involved in your current education), Q11 (you believe your education in this continuation school is important), and Q18 (you put in more time doing your school work at this continuation school than you did at your previous school) as shown in Table 16.

A Kruskal-Wallis test was performed for question variables Q16 (you have many friends within this school), Q17 (you have many friends outside of this school), and Q22 (you feel that you receive more guidance at this school compared to your previous school) and I.V.5 (type of continuation school attended) because these variables did not meet Levene's test for Homogeneity of Variance (Field, 2005; Connolly, 2006). The results showed no statistical significance for any of the variables (shown in Table 17); indicating that type of school attended had no significant effect on students' perceptions related to the above referenced question variables.

\section{Summary of Group One Findings}

In summary of group one findings, questions related to students' perceptions of being prepared for education including parent involvement in the students' education appeared to have been impacted by I.V.2 (previous school type), I.V.3 (home living situation), I.V.4 (grade currently enrolled), and I.V.5 (attendance at traditional/nontraditional continuation school). However, as reviewed in previous pages the effect was fairly minimal for all independent variables referenced above and the dependent question variables, with the exception of I.V.3 and Q16 (you have many friends within this 
school). $r=.44$ indicated a moderate effect of living situation on students' perceptions of having friends within the continuation school.

Finally, statistical analysis of I.V.3 (living situation) and I.V.5 (type of continuation school attended) on variable Q19 (beliefs about preparation for college or work after school) showed a (small) effect as previously reported at $r=.33$ for both. Therefore it was concluded after the analysis of variables that the differing independent variables had only a small affect on students' perceptions related to their continuation school experiences regarding being prepared for education including parent involvement in the students' education.

As shown in Table 6, the total mean response rates range from 1.61 (lowest) to 2.39 (highest), indicated that on average, respondents strongly agreed (value of 1) and agreed (value of 2) with the question variables in group one, which suggested that students overall had positive perceptions of their continuation school experience. A breakdown of students' response percentages for Q9 (your parents/caregiver are very involved in your education), Q10 (you would like your parents/caregiver to be more involved in your current education), Q11 (you believe your education in this continuation school is important), Q16 (you have many friends within this continuation school), Q17 (you have many friends outside of this school), Q18 (you put in more time doing your school work at this continuation school than you did at your previous school), Q19 (you believe you will be well prepared for college or work after you graduate from high school), and Q22 (you feel that you receive more guidance at this school compared to your previous school) can be seen in Figures 2 through 17 (Appendix F). 


\section{Group Two Findings}

Based upon factor analysis, group two included the following dependent question variables: Q12 (you believe that your current teachers think your education is important), Q13 (your current teachers are very supportive), Q14 (your past teachers were very supportive), Q15 (you feel good attending your current continuation school), and Q20 (you believe your teachers want you to succeed). These questions were related to students' perceptions on the importance of education expressed through beliefs about teachers_-past and present_-and their feelings about their continuation school in general. A one-way ANOVA was performed to compare means of the dependent question variables and the independent variables. Additionally, the Games-Howell post hoc test was performed for all variables to account for any variance that may have been present between sample sizes. The number of participants, mean, standard deviation, ANOVA, and statistical significance between the dependent-question variables related to I.V.1 (reason for attending continuation school) are shown in Table 18.

For question variable Q15 (you feel good about attending your current continuation school), the one way ANOVA showed $F(2,59)=3.35, M S E=2.59, p=.04$ statistically significant at $p<.05$. This suggested that there was a relationship between students' reasons for attending a continuation school and their perceptions of feeling good about attending their continuation school. $r=.32$ indicated a small effect size for I.V.1 (reason for attending continuation school) on question variable Q15 (you feel good attending your current continuation school). No other statistical significance was found between I.V.1 (reason for attending continuation school) and any of the other question variables. Additionally, the Games-Howell post hoc test did not yield any statistically 
significant results. Therefore it was concluded that I.V.1 had a minimal effect upon students' perceptions of their continuation school related to perceptions of teachers as well as overall feelings about their continuation school.

For I.V.2 (previous school type attended) a one-way ANOVA was performed and Table 19 shows the number of participants, mean, standard deviation, ANOVA, and statistical significance between the dependent question variables related to I.V.2.

After reviewing the results of the ANOVA there were no statistically significant results to report as shown in Table 19. However, after reviewing the results of the Games-Howell post hoc test a mean difference (1.095) between attending a traditional public school and another alternative setting with a 95\% CI $(.65,1.54)$ significant at $p<$ .05 was found. Additionally there was a mean difference (1.083) between attending a continuation school and another alternative setting with a $95 \%$ CI $(.22,1.95)$ significant at $p<.05$. This indicated that I.V.2 (previous school attended) did have some affect on question variable Q20 (you believe your teachers want you to succeed). However, $r=.23$ indicated that the affect size was very small, which was in line with the original ANOVA findings. Therefore, I.V.2 (previous school type attended) had a minimal effect on students' perceptions of their teachers and continuation school.

For I.V.3 (living situation), a one-way ANOVA was performed and the number of participants, mean, standard deviation, ANOVA, and statistical significance of the responses related to I.V.3 are shown in Table 20.

For I.V.3 (living situation) the one-way ANOVA showed $F(4,56)=4.77, M S E=$ $3.23, p=.001$, statistically significant at $p<.05$. This indicated that I.V.3 did have an impact on dependent question variable Q15 (you feel good attending your current 
continuation school), students' perceptions related to feeling good about attending your current continuation school. The effect size showed $r=.50$ which indicated that I.V.3 had a moderate to large effect on question variable Q15 (you feel good about attending your continuation school).

Dependent question variables Q12 (you believe that your current teachers think your education is important), Q13 (your current teachers are very supportive), Q14 (your past teachers were very supportive), and Q20 (you believe your teachers want you to succeed) did not have any statistically significant findings to report. Additional analysis of the Games-Howell post hoc test did not show any statistically significant findings. Therefore it can be concluded that I.V.3 (living situation) did not have any statistically significant effect upon students' perceptions of these question variables related to students' perceptions about their current and past teachers.

For I.V.4 (grade currently enrolled), a one-way ANOVA was performed and the number of participants, mean, standard deviation, ANOVA, and statistical significance (if any) between the dependent question variables related to I.V.4 (grade currently enrolled) are shown in Table 21.

For I.V.4 (grade currently enrolled), as shown in Table 21, there were no statistically significant findings after analysis of the ANOVA. Additionally, after review of the Games-Howell post hoc test there were no statistically significant findings to report. For the question variables that did not meet Levene's test of Homogeneity of Variance [Q12 (you believe that your current teachers think your education is important), Q14 (your past teachers were very supportive), Q15 (you feel good attending your current 
continuation school)], a Kruskal-Wallis test was performed. After analysis of the results of this last test, there were no statistically significant findings to report (see Table 22).

Based on these results, it was concluded that I.V.4 (grade currently enrolled) did not have any statistically significant effect upon any of the dependent question variables related to students' perceptions about their continuation school including perceptions of current and past teachers. Nor did I.V.4 (grade currently enrolled) have any effect upon students' perceptions related to good feelings about attending their continuation school.

For I.V.5 (type of continuation school attended) a one-way ANOVA was performed with the Games-Howell post hoc test to account for any variance in the samples. The number of participants, mean, standard deviation, ANOVA, and statistical significance (if any) between the dependent question variables related to I.V.5 are shown in Table 23.

For I.V.5 there were statistically significant results of the one-way ANOVA found between dependent question variable Q15 (you feel good attending your current continuation school) and I.V.5 (type of continuation school attended). The one-way ANOVA showed $F(1,60)=7.55, M S E=5.69, p=.01$, statistically significant at $p<.05$. This indicated that I.V.5 had an effect on question variable Q15 (you feel good attending your current continuation school). The effect size $r=.33$ indicated a small effect. It should be noted that the Games-Howell post hoc test could not be performed with I.V.5 (type of continuation school attended) because there were less than three means to compare. The above-mentioned result was the only statistically significant finding for this independent variable in relation to the dependent question variables. Therefore it can be concluded that I.V.5 (type of continuation school attended) did not have any 
statistically significant effect on question variables that specifically related to students' perceptions about their teachers, past or present. There was only a small effect observed regarding students' perceptions about good feelings toward attending their current continuation school.

\section{Summary of Group Two Findings}

It can be concluded from the analysis of group two dependent question variables and the independent variables that question variables related to students' perceptions about their teachers, past and present, were not affected by any of the independent variables. The one significant finding was the moderate effect $(r=.50)$ of students' living situation (I.V.3) on students' perceptions related to good feeling about attending their continuation school (Q15). Thus depending on where students live (i.e. group home, with a parent, with a relative, with a foster parent, or on their own) the independent variable had an effect on how students feel about attending their continuation school.

Yet, despite the lack of statistically significant findings between the groups, students overall responded very positively to the dependent question variables presented in the survey. This is shown in the percentage breakdown of students' answers to survey questions of those in group two. The breakdown of students' response percentages for Q12 (you believe that your current teachers think your education is important), Q13 (your current teachers are very supportive), Q14 (your past teachers were very supportive), Q15 (you feel good attending your current continuation school), and Q20 (you believe your teachers want you to succeed) can be seen in Figures 18 through 25 (Appendix F). 


\section{Summary}

As alluded to earlier, students overall responded more positively than negatively to questions about their perceptions of their continuation high school. In Figure 27, an interesting difference can be seen between the traditional and non-traditional continuation school settings. In the traditional continuation school setting, $16 \%$ of student participant respondents disagreed or strongly disagreed with the statement that they believed their teachers wanted them to succeed while $5 \%$ in the non-traditional continuation school setting disagreed with this same statement. While more students strongly agreed or agreed with this statement as shown in Figures 26, overall, students in the non-traditional setting rated this question more positively than negatively-63\% strongly agree and agree. In the traditional setting, the percentage of students who strongly agreed or agreed with this same statement was higher at $80 \%$.

Based upon students' overall response percentages, when looking at responses to dependent variable questions in group one and group two, students attending the nontraditional continuation school rated more positively than negatively-as defined by ratings of strongly agree and agree - their perceptions based on the dependent variable questions. This is shown in Table 24.

Further, based upon findings for group one and group two, dependent question variables when analyzed with the independent variables showed some effect in regard to the independent variables. For example, I.V.3 (living situation) did have an effect on how students perceived their preparation for college or work after high school (Q19); students' good feelings about attending their continuation school (Q15); and also desired parental involvement (Q10). For I.V.5 (type of continuation school attended), there was 
significant effect on how students perceived their preparation for college or work after high school (Q19) and also students' good feelings about attending their continuation school (Q15). The effects were observed as small to moderate in effect size.

Interestingly, perceptions about friends, teachers (past and present), importance of education, and parent/caregiver involvement (current) really were not significantly affected by any of the independent variables. This leaves room for further research and analysis (to be discussed in Chapter Five). 


\section{CHAPTER FIVE}

\section{SUMMARY/CONCLUSION}

The purpose of this study was to allow African-American students attending two different continuation high schools, one traditional model and one non-traditional model (refer to the Definition of Terms for discussion of the difference in the models) to express their perceptions of their continuation school experiences. Their responses were based on a 5-point Likert scale survey and two open-ended questions. Additionally, this researcher wanted to provide a structured opportunity for these students to anonymously express their perceived feelings about their continuation school. They were given the opportunity to express their feelings about preparation for work or college after graduation, parent or caregiver involvement (actual and desired), and their experiences related to teachers (past and present) within the continuation school setting. Information was collected during this research study related to demographic information such as gender, reasons for attending the continuation school, living situation, type of school attended previously, current grade enrollment, and attendance at a traditional or non-traditional continuation school. The demographic information became the independent variables for the dependent questions variables to be analyzed with, as a means of determining if the demographic information had any effect on students' perceptions of their continuation school experiences.

This study had one essential guiding research question: What are the experiences of African-American students who attend continuation schools related to self-esteem, education-previous, current, and post continuation school placement—and does this affect their outlook on their futures? This research question was addressed through the following four hypotheses that evolved out of that research question. 


\section{Hypotheses}

1. Students with discipline issues will rate their continuation high school experiences more positively than negatively.

2. Students with reportedly low parent/caregiver involvement will rate their continuation high school experiences more positively than negatively.

3. Student responses to survey questions will be more positive than negative as they rate their perceptions of their continuation school teachers.

4. Students in a non-traditional continuation high school will respond more positively than negatively about their continuation high school experiences when compared to students in a traditional continuation high school.

The embedded principles that guided this researcher included beliefs that students who attend continuation schools would express more positive than negative perceptions of their continuation school experiences because of research that studies the abundance of services and caring that seems to occur in that particular setting. It was expected that this type of support would promote feelings of pride within students who may have had more negative than positive experiences within the traditional public school system. Further, it was assumed that the traditionally small nature of continuation schools would provide students with higher esteem toward their continuation school.

A total of 62 African-American students - 48 males and 14 females-participated in this research study. Based on factor analysis of the data to obtain trends present in the survey questions, two trends emerged. Trend one included question variables that concerned students' perceptions of being prepared for education including parent involvement in the students' education. Trend two included question variables that were 
concerned with students' perceptions on the importance of education expressed through beliefs about teachers and their feelings and their continuation school in general. In the following section, a review of the findings reported in Chapter Four and the hypotheses is evaluated to determine if the overarching research question can be answered.

\section{Summary of Findings}

\section{Hypothesis One}

When exploring hypothesis one: Students with discipline issues will rate their continuation high school experiences more positively than negatively, the hypothesis was found to be evidenced by the data. After reviewing the survey results, 28 students total reported that they were attending a continuation school for discipline issues. Of those 28 students, 26 students attended the non-traditional continuation school. As reported in Chapter Four, the one-way ANOVA between I.V.1 (reasons for attending a continuation school- discipline; credit recovery; both) and question variable Q15 (you feel good attending your current continuation school) showed $F(2,59)=3.35, M S E=2.59, p=.04$ statistically significant at $p<.05$ with $r=.32$. This indicated a small effect size for I.V.1 (reason for attending continuation school) on question variable Q15 (you feel good attending your current continuation school). No other statistically significant findings were observed between I.V.1 and the remaining dependent question variables. Interestingly, the student response percentage for Q15 (you feel good about attending your continuation school), showed that students at the traditional continuation school responded more positively than negatively to this question variable, with $88 \%$ responding strongly agree and agree. This is in comparison to $65.7 \%$ of the non-traditional continuation school attendees who answered strongly agree and agree to this question 
variable. Despite this finding, as mentioned previously, overall, students at the nontraditional continuation school responded more positively than negatively (characterized previously) to 7 of the 13 question variables. This indicated that students at the nontraditional continuation school rated their perceptions of their continuation school more positively than negatively when compared to the students attending the traditional continuation school model. Since more students (26 out of 37) attending the nontraditional continuation school reported their reason for attendance as being related to discipline issues, it can be concluded that students who attend the non-traditional continuation school for discipline issues had a more favorable perception of their continuation school.

\section{Hypothesis Two}

In the case of hypothesis two: Students with reportedly low parent/caregiver involvement will rate their continuation high school experiences more positively than negatively; the hypothesis was not evidenced by the data. After analysis of the data, it was apparent that students who rated more positive than negative experiences at the continuation school also reported that their parent/caregivers were involved in their education. Of the student response percentages for question variable Q9 (your parents/caregiver are very involved in your education), $76 \%$ and $84 \%$ of the students attending the traditional continuation school and students attending the non-traditional continuation school respectively, responded as strongly agree and agree with this question. This indicated that students overall had a positive perception of their parent/caregiver involvement in their continuation school experience. Thus it can be concluded that this hypothesis was not supported by the data, indicated by students' 
reporting of positive experiences at the continuation school and the above referenced percentage of students who rated more positively than negatively their parent/caregiver involvement.

\section{Hypothesis Three}

For hypothesis three: Student responses to survey questions will be more positive than negative as they rate their perceptions of their continuation school teachers. Overall, students responded more positively than negatively to question variable Q13 (your current teachers are very supportive) with $72 \%$ and $65.4 \%$ of students attending the traditional continuation school and the non-traditional continuation school respectively, responding as strongly agree and agree.

Additionally, with regard to question variable Q20 (you believe your teachers want you to succeed), students' response percentages were slightly more positive than negative at the non-traditional continuation school at $63 \%$ compared to the traditional continuation school student response percentage of $61 \%$ agreement with question variable Q20. Interestingly, students at the traditional continuation school perceived that their current teachers wanted them to succeed more than students at the non-traditional continuation school. This was evidenced through $68 \%$ agreement with question variable Q12 (you believe that your current teachers think your education is important) from students attending the traditional continuation school and $76 \%$ positive responses by students attending the non-traditional school.

Lastly, students in the traditional continuation school had a low response percentage for question variable Q14 (your past teachers were very supportive), with only $28 \%$ of students responding more positively than negatively_evidenced by a rating of 
strongly agree and agree-with regard to this question variable. Students at the nontraditional continuation school had a response percentage rate of $45.4 \%$ which indicated that these students had more positive than negative experiences with regard to past teachers. These results overall indicate that students expressed more positive than negative perceptions of their current continuation school teachers. Regarding students' perceptions of their past continuation school teachers, students at the traditional continuation school appeared to have had less favorable perceptions of their past teachers. While there are reasons why such a phenomenon may occur, including the small nature of the school and also class size, students may have received what they believed to be more attention from their continuation school teachers. This is only speculative as this research study survey did not ask specific questions that addressed reasons for students' perceptions of their current and past teachers. Yet, it can still be concluded that this hypothesis was supported by the data as students did have more positive than negative perceptions of their continuation school teachers.

\section{Hypothesis Four}

The fourth and final hypothesis: Students in a non-traditional continuation high school will respond more positively than negatively about their continuation high school experiences when compared to students in a traditional continuation high school. This hypothesis was evidenced by the data. The non-traditional continuation school had a residential component which would seem to have been related to students' overall positive perceptions of their continuation school. As shown in Chapter Four, when analyzing I.V.3 (living situation) with the dependent question variable Q15 (you feel good attending your current continuation school) statistically significant results were 
found from the one-way ANOVA $F(4,56)=4.77, M S E=3.23, p=.001$, statistically significant at $p<.05$. The effect size showed $r=.50$ which indicated that I.V.3 had a moderate to large effect on question variable Q15 (you feel good attending your current continuation school). Additionally, there were statistically significant findings between I.V.3 (living situation) and question variable Q16 (you have many friends within this school). The one-way ANOVA between I.V.3 (living situation) and Q16 (you have many friends within this school), $F(4,56)=3.42, M S E=4.05, p=.01$, statistically significant at $p<.05$ with $r=.44$, indicated a moderate effect of living situation on students' perceptions of having friends within the continuation school. The perception of having friends within your current school may have been linked to students' positive perceptions of their continuation school environment. This last statement is speculative in nature as the survey did not gather data related to this phenomenon. However, this could be a point of future study. Living situation did not yield any additional statistically significant findings in relation to the remaining question variables. Yet when examining the student response percentages, a comparison of students' responses indicated more positive than negative responses—characterized by student responses of strongly agree and agreefrom those students attending the non-traditional continuation school when compared to responses from students attending the traditional continuation school. Out of the 13 dependent question variables, seven question variables were answered more positively than negatively (characterized in the previous sentence) by students attending the nontraditional continuation school. The last statement suggests that students attending the non-traditional continuation high school perceived their continuation school experiences 
more positively than negatively, when compared to students attending the traditional continuation school.

\section{Response to the Research Question}

As alluded to earlier in this chapter, the four hypotheses evolved out of the overarching research question that asked: What are the experiences of African-American students who attend continuation schools related to self-esteem, education-previous, current, and post continuation school placement—and does this affect their outlook on their futures? The information that resulted from analysis of the data suggested that African-American students who attend continuation schools overall have positive experiences in those schools and more often than not believe they will be well prepared for work or college after graduation from high school. As reported in previous sections, students appeared to respond more positively than negatively—characterized by a response of strongly agree and agree- to all question variables with the exception of question variables Q14 (your past teachers were very supportive) and Q22 (you feel that you receive more guidance at this school compared to your previous school). These questions asked student participants if they perceived their previous teachers as being supportive and if they perceived themselves as receiving more guidance at their continuation school than their previous school. Potential reasons why respondents answered question variable Q14 (your past teachers were very supportive) more negatively than positively at the traditional continuation school have been previously explored within the summary of hypothesis three.

However, students' perceptions of receiving more guidance at the non-traditional continuation school did not align with students' ratings for other question variables. All 
other responses related to perceiving that they were supported by current teachers, had parent/caregiver involvement, and good feelings about attending their continuation school were more positive than negative. Students also responded that they perceived they would be well prepared for work or college following graduation (as reported previously); however, students' perceptions regarding the guidance they receive at the current continuation school was rated among the lowest in student responses at $62.5 \%$ for the non-traditional continuation school. This did not seem to be an issue at the traditional continuation school where students rated this item more positively than negatively at $80 \%$.

One potential reason for students at the non-traditional continuation school perceiving that they receive less guidance at their current school than their previous school may be related to the lack of access to counseling personnel at the school site. Additionally according to Kelly (1993), "in many districts, student-teacher ratios were actually higher at continuation schools than they were at conventional high schools" (p. 81). Therefore, "districts can undercut the promise of more individual attention for students ... with extra duties under the rubric of 'alternative education"' (p. 81). However, according to data for the 2009-10 academic year accessed through the CDE website, the non-traditional continuation school had no pupil services full-time equivalent (FTE) workers for the 144 students enrolled during that academic year. This indicated that students did not have access to a counselor on site. This information was also found in the schools accountability report card. This would appear to undercut the extra time and attention students should be receiving in the continuation school setting as suggested by Kelly. This is possibly a reason for the students' lower rating of question variable 
Q22 (you believe you receive more guidance at this school compared to your previous school). This area would benefit from further research, specifically in an attempt to ascertain the reason for the anomaly and the general analysis of student services available to students attending the continuation school.

When analyzing the research question based upon the data collected from the respondents, the African-American students appeared to have more positive than negative perceptions about their current continuation school and the outlook for their futures.

\section{Implications for Further Research}

While this research study gathered information related to students perceptions of their continuation school experiences, it will become the second part of a three-part study this researcher is envisioning regarding the effectiveness of continuation schools. When looking at how African-American students move into alternative education, specifically how they come to attend a continuation school, we must address the factors of risk that affect these students. According to Vesely et al. (2008), African-American students are at-risk of school failure because they are an ethnic minority group. This category presumes that all ethnic minority groups are at-risk for school failure. Recall from Chapter Two that there were six categories of risk defined which place students at-risk for school failure and they include the following: students who may need additional resources to be academically successful, and encompass low-income students, students with disabilities, ethnic minority students, English Language Learners (ELLs), children in urban schools, and students from families with low parental education attainment. Specifically addressing the category of ethnic minority, let us revisit why students within 
this category may need additional support within the current traditional public school system.

Cuddapah et al. (2008) suggested that risk was related to a lack of self-confidence and success in academic endeavors, along with negative behavior patterns of isolation both mentally and physically from the school environment. Education in its current form actually negates education and knowledge as a process of inquiry and instead teaches students what to think, not how to think, thereby perpetuating the oppressive nature of society (Freire, 1970). One way that this occurs in schools is through silencing (hooks, 1994); where the students' voices are removed from the classroom and critical engagement in the curricular content is not promoted because students often struggle to relate to the curriculum. As Banks (2006) suggested, we do not have curriculum that is reflective of the diverse groups of students currently being educated in American schools. It is this researcher's opinion that there is a direct link between the current curricular structure and African-American students' disengagement from traditional public education. As a result, these students move out of traditional public education and into alternative education, specifically continuation schools. As previously stated, this research study was envisioned as a second part of a three-part research series seeking to address the effectiveness of continuation schools. Therefore, for further study, part one of the three-part series should evaluate the disengagement of African-American students related to information referenced in this paragraph and in Chapter Two. Additionally, further research in this area should also include program and curriculum review for those programs that attempt to address such issues as those previously mentioned to determine 
successful models for keeping African-American students engaged in traditional public education.

Research related to students' earning potential after graduating from a continuation school should be another point of further study. As was previously discussed in Chapter Two, we see a clear connection between the education of the individual and their earning potential according to Aron (2006, cited in NCES, 2010). The terminology surrounding continuation school attendance seems to be steeped in negative connotation as often it is implied that students did not have necessary characteristics to achieve success within the traditional public education system. In the early 20th century, perceptions of the continuation school student were less than favorable. Trout (1937) discussed the role of the continuation educator as the following: Whoever had the idea that one person could take twenty or thirty or even ten continuation students and instruct them in the things they should know and make them like it must have been the champion day-dreamer of the ages . . They [continuation students] represent the moron and the genius, the social misfit and the socially unfit, the rich man's misunderstood daughter and the poor man's understood son, together with the bewildered and groping foreign born. I don't know of anyone in America who isn't represented, nor anyone in America capable of handling them as a single group. (pp. 182-183)

It is this researcher's opinion that this perception still lingers in the back of the minds of many today. Thoughts such as these could conceivably lead individuals and students to believe that continuation school teachers do not possess the capacity to help students achieve high levels of academic success or earning potential. Research linked to 
what happens to students after graduation from a continuation school is much needed to address the effectiveness of continuation schools. Therefore, for further study, part three of the three-part series this researcher envisions should evaluate the after effects of attending a continuation school in leading students to employment, college, or delinquency.

Research of the above-mentioned nature could attempt to address the inconsistencies currently present in measuring the effectiveness of continuation schools. As discussed in Chapter Two, because continuation schools fall under the ASAM model of accountability, and administrators are allowed to choose which three indicators of success they want to report, “. . . there is no way to compare performance across schools in this system" (De Velasco, 2008, p. 20). According to Williamson (2008), most of the indicators only count students who have attended the school for at least 90 days. Further, it is because of the continually shifting continuation school population, most schools do not have enough "valid" measures to qualify for an API or AYP (Williamson, 2008). Research conducted at multiple continuation school sites that relates to students' success or lack thereof after graduation from a continuation school, coupled with research regarding reasons for attending a continuation school, inquiry into what services AfricanAmerican students receive while attending the continuation school, and the perceptions of these students related to their continuation school experiences is imperative. Information of this nature could provide educators a clear picture to help inform the discourse surrounding continuation schools and the achievement of African-American students. 


\section{Recommendations for Further Research}

With regard to continuing research in line with this study, this researcher recommends adding a qualitative component to address further issues unearthed by the raw data in the surveys. This researcher believes this would be a valid addition to this study in order to address the aforementioned anomaly regarding students' perceptions about guidance at their current continuation school. Additionally, this researcher believes this study would benefit from replication in several districts of varying socioeconomic status in order to ascertain any differences among populations.

\section{Conclusion}

As stated in Chapter One, there were certain delimitations for this research study. Those included a potential lack of generalizability to other continuation school sites as well as to other ethnic minority populations. Additionally, this study did not compare the effectiveness of one type of alternative education school to another, such as a continuation school compared with a charter school. The study examined the relationship between attending a continuation high school and the degree of students' perceptions about whether they are supported and engaged in education. The results showed how favorably the students viewed their experiences in a continuation school compared to their previous school experiences. Further, this study provided a foundation for further questioning and research to consider what happens prior to students disengaging from traditional public education and after students graduate from a continuation school, should they make it to graduation. Completing this study helped this researcher to take note of the importance of situating any future discussion about African-American students and alternative education, specifically continuation schools, in the context of 
engagement versus disengagement. According to Kelley (1993) and Williamson (2008), these teens have been classified as dropouts-the responsibility falls upon the student for leaving school—or as push-outs— the responsibility falls upon the institution for failing to keep students engaged. However, Kelly suggested the term of disengagement be used when discussing why students must seek education in an alternative education setting. The use of the term disengagement ". . . connotes a long-running, interactive process which may be reversible ..." and “. . . encourages us to connect events in students' lives over time and look for cumulative effects" (p. 29). A follow-up question to be considered would be: What effect does disengagement from the traditional public education system, attending a continuation school, and graduation from a continuation school have on college attendance, employment, and earnings of students?

Finally, this study has implications for how students are identified for alternative education and subsequently educated. Through continued research, the disparities and inequities that occur in the traditional public education system that result in students transferring into continuation schools could be further explored. When conducting future research, it is imperative that the course of study is deliberate and systemic in nature to address the needs of African-American students enrolled in alternative education, specifically continuation schools. Ultimately, if society can address these inequities on a systemic level and incorporate the cultures of diverse students that attend our nation's schools, then students will be better prepared and equipped in becoming democratic citizens who are able to perpetuate a true democracy through public education. 


\section{REFERENCES}

Alexander, K. \& Alexander M. D. (2005). American Public School Law. Belmont, CA: Thomas Learning Inc.

Aronowitz, S. (2004). Against schooling: Education and social class. Social Text, vol. 22, 2004, pp. 13-35.

Banks, J. A. (2006). Race, culture, and education: The selected works of James A. Banks. New York, NY: Routledge.

California Department of Education (2009). Enrollment in educational options for the year 2009-10 [Data file]. Retrieved from http://dq.cde.ca.gov/dataquest/DQ/EdOptions. aspx?TheYear=20090\&TheRpt=StAltEd\&cLevel=State $\&$ Topic $=$ Enrollment $\&$ Code $=2$.

California Department of Education. (2010a). Dropouts by ethnic designation by grade [Data file]. Retrieved from http://dq.cde.ca.gov/dataquest/DropoutReporting/GradeEth .aspx $?$ cDistrictName $=$ State $\&$ cCountyCode $=00 \&$ DistrictCode $=0000000 \& c S c h o o$ 1Code $=0000000 \&$ Level $=$ State $\&$ TheReport $=$ GradeEth $\&$ ProgramName $=$ All $\& c$ Yea $\mathrm{r}=200809 \& \mathrm{cAggSum}=$ StTotGrade\&cGender $=\mathrm{B}$.

California Department of Education. (2010b). The model continuation school [Data file]. Retrieved from http://www.cde.ca.gov/nr/ne/yr09/yr09rel34.asp.

California Department of Education (2010c). Continuation education: Caledfacts [Data file]. Retreived from http://www.cde.ca.gov/sp/eo/ce/cefcontinuationed.asp.

California Department of Education (2010d). Educational options [Data file]. Retrieved from http://www.cde.ca.gov/sp/eo/. 
California Department of Education (2010e). Alternative schools accountability model $(A S A M)$ [Data file]. Retrieved from http://www.cde.ca.gov/ta/ac/am/.

Carver, P. R., and Lewis, L. (2010). Alternative schools and programs for public school students at-risk of educational failure: 2007-08 (NCES 2010-026).

U.S. Department of Education, National Center for Education Statistics. Washington, DC: Government Printing Office.

Connolly, P. (2006). Quantitative data analysis in education: A critical introduction using SPSS. New York, NY: Routledge.

Cuddapah, J. L., Masci, F. J., Smallwood, J. E., and HollandJ. (2008). A Professional development school-sponsored summer program for at-risk secondary students. NASSP Bulletin, vol. 92, no. 4, 2008, pp. 261-275.

De Velasco, J. R. (2008). Alternative education in continuation high schools: Meeting the needs of over-aged under-credited youth [Data file]. Retrieved from http://gardnercenter.stanford.edu/docs/Cont\%20HS\%20Ap\%2008\%20fin.pdf.

DeCuir-Gunby, J. T. (2009). A review of racial identity development of African American adolescents: The role of education. Review of Education Research, vol. 1, no. 1, 2009, pp. 103-124.

Delgado, R. (1990). When a story is just a story: Does voice really matter? Virginia Law Review, vol. 76, no. 1, 1990, pp. 95-111.

Delgado, R. \& Stefancic, J. (2001). Critical race theory: An introduction. New York, NY: University Press.

Dewey, J. (1916). Democracy and education. New York, NY: The MacMillan Company. 
Dixson, A. D. \& Rousseau, C. K. (2005). And we are still not saved: Critical race theory in education ten years later. Race Ethnicity and Education, vol. 8, no. 1, 2005, pp. 7-27.

EdSource (2008a). California's continuation schools. Retrieved from: http://www.edsource.org/pub_Continuation5-08.html.

Ferguson, R. F. (2002). What doesn't meet the eye: Understanding and addressing racial disparities in high-achieving suburban schools [Data file]. Retrieved from http://www.hks.harvard.edu/inequality/Seminar/Papers/Ferguson.pdf.

Field, A. (2005). Discovering statistics using SPSS. Thousand Oaks, CA: Sage Publications Ltd.

Fine, M. (1991). Framing dropouts: Notes on the politics of an urban public high school. Albany, NY: State University of New York Press.

Freire, P. (1970). Pedagogy of the oppressed. (Transl Myra Bergman Ramos). New York: Continuum.

Gay, L. R., Mills, G. E., Airasian, P. (2009). Educational research: Competencies for analysis and applications. Upper Saddle River, NJ: Pearson Education, Inc.

Giroux, H. A. (1988). Schooling and the struggle for public life: Critical pedagogy in the modern age. Minneapolis, MN: University of Minnesota Press.

Giroux, H. A. (2009). Teacher education and democratic schooling. In A. Darder, M. P. Baltodano, \& R. D. Torres (Eds.), The critical pedagogy reader $\left(2^{\text {nd }}\right.$ Ed.). (pp. 438-459). New York, NY: Routledge. 
Gosa, T. L. \& Alexander, K. L. (2007). Family (dis)advantage and the educational prospects of better off African American youth: How race still matters. Teachers College Record, vol. 109, no. 2, 2007, pp. 285-321.

hooks, b. (1994). Teaching to transgress. New York, NY: Routledge.

Howard, T. C. (2008). Who really cares? The disenfranchisement of African American males in PreK-12 schools: A critical race theory perspective. Teachers College Record, vol. 110, no. 5, 2008, pp. 954-985.

Jones, A. J. (1907). The continuation school in the United States. Retrieved from google scholar, September 1, 2010. http://books.google.com/books?hl=en\&lr=\&id=aWdIAAAAYAAJ\&oi=fnd\&pg= PA5\&dq=continuation+schools\&ots=Ts01WiddM\&sig=YDCwrJeW5fVBXjyNC $1 \_4 F s x$ RUU\#.

Kelly, D. M. (1993). Last chance high: How girls and boys drop in and out of alternative schools. Ann Arbor, MI: Edwards Brothers.

Kim, J. H. (2006). For whom the school bell tolls: Conflicting voices inside an alternative high school. International Journal of Education \& the Arts, vol. 7, no. 6, 2006, pp. 1-19.

Kim, J. H. \& Taylor, K. A. (2008). Rethinking alternative education to break the cycle of educational inequality and inequity. Journal of Education Research, vol. 101, no. 4, 2008, pp. 207-219.

Kumashiro, K. (2000). Toward a theory of anti-oppressive education. Review of Educational Research, 70(1), 25-53. 
Ladson-Billings, G. \& Tate IV, W. F. (1995). Toward a critical race theory of education. Teachers College Record, vol. 97(1), pp. 47-68.

Lange, C. M. \& Sletten, S. J. (2002). Alternative education: A brief history and research synthesis. (Project FORUM No. H159K70002). Alexandria, VA: U.S. Department of Education.

Levin, H. (1990). The educationally disadvantaged are still among us. In J. G. Bain \& J. L. Herman (Eds.), Making schools work for underachieving minority students: Next steps for research, policy and practice. (pp. 3-11). Westport, CT: Greenwood Publishing Group, Inc.

Matsuda, M. (1995). Looking to the bottom: Critical legal studies and reparations. In K. Crenshaw, N. Gotanda, G. Peller, \& K. Thomas (Eds.), Critical race theory: The key writings that formed the movement (pp. 63-79). New York: The New Press.

National Center on Education and the Economy. (2006). An overview of alternative education. (USDOL Publication No. AF-14604-05-06). Washington, DC: U.S. Government Printing Office.

National Center for Education Statistics. (2010). Alternative schools and programs for public school students at-risk of educational failure: 2007-08. [Data file]. Retrieved from http://nces.ed.gov/pubs2010/2010026.pdf.

"Nonpublic schools fact sheet". (n.d.) Retrieved from http://www.cacfs.org/files/advocacy/NonPublicSchoolFactSheetDraft-final.doc Ogbu, J. U. (1981). School ethnography: A multilevel approach. Anthropology \& Education Quarterly, vol. 12 (1), pp. 3-29. 
Ogbu, J. U. (1987). Variability in minority school performance: A problem in search of an explanation. Anthropology \& Education Quarterly, vol. 18 (4), pp. 312-334.

Ogbu, J. U. (2003). Black American students in an affluent suburb: A study of academic disengagement. Mahwah, NJ: Lawrence Erlbaum Associates.

Perez, L. G. and Johnson, J. F. (2008). California continuation high schools: A descriptive study [Data file]. Retrieved from http://www.ncust.org/dnn/Portals/0/NCUSTResources/Lynnes\%20paper\%20for\% 20Irvine.pdf.

Perry, T., Steele, C., \& Hilliard, C. (2003). Young, gifted, and Black. Boston: Beacon Press.

Raywid, M. A. (1982). The current status of schools of choice in public secondary education: Alternatives, options, magnets. (National Institute of Education No. G-80-0194). Washington, DC: U.S.

Raywid, M. A. (1994). Alternative schools: The state of the art. Educational Leadership, vol. $52(4)$, pp. 26-31.

Rumberger, R. W. \& Gandara, P. (2004). Seeking Equity in the Education of California's English Learners. Teachers College Record, vol. 106, no. 10, 2004, pp. 20322056.

Shor, I. (1999). What is critical literacy? In I. Shor \& C. Pari (Eds.), Critical literacy in action: Writing words, changing worlds. (pp. 1-31). Portsmouth, NH: BoyntonCook/Heinemann.

Tissington, L. D. (2006). History: Our hope for the future. Preventing School Failure, vol. 51(1). pp. 19-26. 
Trout, G. G. (1937). The ills of continuation in California. California Journal of Secondary Education, 12(January-December), pp. 180-183.

University of Wisconsin. Minority student achievement network. Retrieved from http://www.msanetwork.org/index.aspx.

U.S. Department of Education. (2010a) No child left behind [Data file]. Retrieved from http://www.ed.gov/policy/elsec/leg/esea02/index.html.

U.S. Department of Education. (2010b). Summer 2010 edfacts state profile-California [Data file]. Retrieved from http://www2.ed.gov/about/inits/ed/edfacts/stateprofiles/california.pdf.

U.S. Department of Education. (2010c). Status and trends in the education of racial and ethnic minorities [Data file]. Retrieved from http://nces.ed.gov/pubs2010/2010015/tables/table_11_1.asp.

U.S. Department of Education. (2010d). Status and trends in the education of racial and ethnic minorities [Data file]. Retrieved from http://nces.ed.gov/pubs2010/2010015/tables/table_11_2.asp

Vadeboncoeur, J. A. (2009). Spaces of difference: The contradictions of alternative educational programs. Educational Studies, vol. 45, 2009, pp. 280-299.

Vanneman, A., Hamilton, L., Anderson, J. B., and Rahman, T. (2009). Achievement gaps: How Black and White students in public schools perform in mathematics and reading on the national assessment of educational progress, (NCES 2009455). National Center for Education Statistics, Institute of Education Sciences, U.S. Department of Education. Washington, DC. 
Vesely, R. S., Crampton, F. E., Obiakor, F. E., and Sapp, M. (2008). The role of states in funding education to achieve social justice. Journal of Education Finance, vol. 34 no. 1, (Summer 2008), pp. 56-74.

Wiest, D., Wong, E. H., Kreil, D. A. (1998). Predictors of global self-worth and academic performance among regular education, learning disabled, and continuation high school students. Journal of Adolescence, vol. 33, no. 131, 1998, pp. 601-619.

Williamson, D. (2008). Legislative history of alternative education: The policy context of continuation high schools. Paper presented at the AERA Annual Meeting. Retrieved from http://gardnercenter.stanford.edu/docs/Alternative\%20Education\%20History.pdf. Young, T. (1990). Public alternative education. New York, NY: Teachers College Press. 


\section{TABLES}

Table 1

Student Demographics: Traditional Continuation High School A

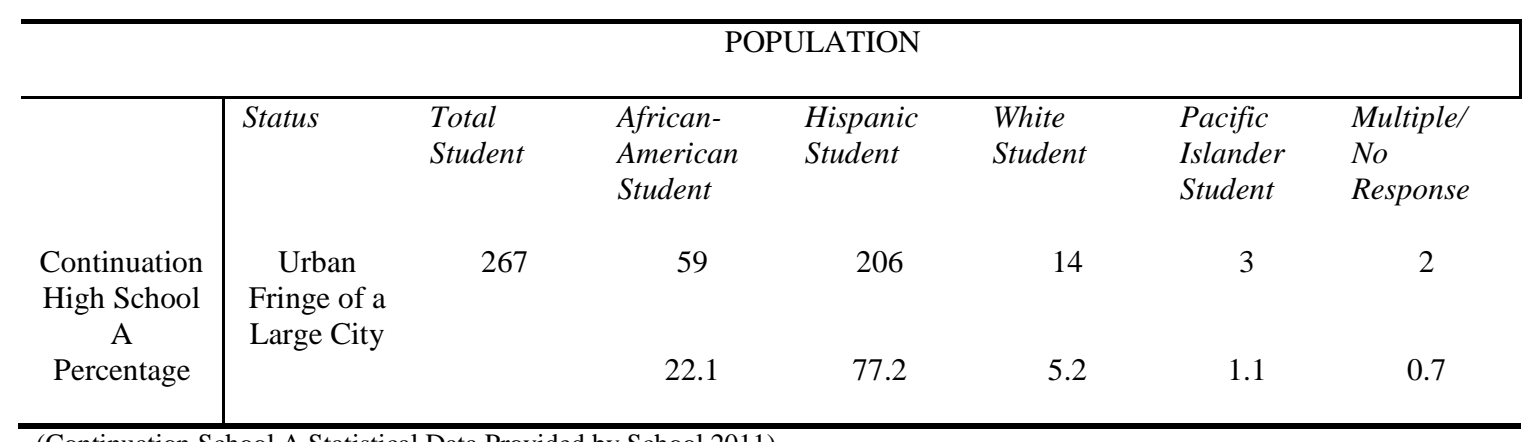

(Continuation School A Statistical Data Provided by School 2011) 
Table 2

Student Demographics: Non-Traditional Continuation High School B

\begin{tabular}{|c|c|c|c|c|c|c|c|c|c|}
\hline \multicolumn{10}{|c|}{ POPULATION } \\
\hline & Status & $\begin{array}{l}\text { Total } \\
\text { Student }\end{array}$ & $\begin{array}{l}\text { African- } \\
\text { American } \\
\text { Student }\end{array}$ & $\begin{array}{l}\text { Hispanic } \\
\text { Student }\end{array}$ & $\begin{array}{l}\text { American } \\
\text { Indian } \\
\text { Student }\end{array}$ & $\begin{array}{l}\text { Filipino } \\
\text { Student }\end{array}$ & $\begin{array}{l}\text { Asian } \\
\text { Student }\end{array}$ & $\begin{array}{l}\text { White } \\
\text { Student }\end{array}$ & $\begin{array}{l}\text { Multiple/ } \\
\text { No } \\
\text { Response }\end{array}$ \\
\hline $\begin{array}{c}\text { Continuation } \\
\text { High School } \\
\text { B }\end{array}$ & $\begin{array}{c}\text { Urban } \\
\text { Fringe } \\
\text { of a } \\
\text { Large } \\
\text { City }\end{array}$ & 148 & 39 & 93 & 0 & 0 & 0 & 16 & 0 \\
\hline Percentage & & & 26.4 & 62.8 & 0 & 0 & 0 & 10.8 & 0 \\
\hline
\end{tabular}

(Continuation School B Statistical Data Provided by School 2011) 
Table 3

Student Participants

\begin{tabular}{c|ccc}
\hline & Males & Females & Total \\
\hline School A & 11 & 14 & 25 \\
School B & 37 & 0 & 37 \\
Total & 48 & 14 & 62 \\
\hline
\end{tabular}


Table 4

Factor Loadings for Exploratory Factor Analysis with Oblimin Rotation with Kaiser Normalization in Principal Component Analysis

\begin{tabular}{|c|c|c|}
\hline & \multicolumn{2}{|c|}{ Component } \\
\hline & 1 & 2 \\
\hline $\begin{array}{l}\text { You believe you will be well prepared for } \\
\text { college or work after you graduate from } \\
\text { high school? (Q19) }\end{array}$ & .989 & \\
\hline $\begin{array}{l}\text { You have many friends outside of this } \\
\text { school? (Q17) }\end{array}$ & .848 & \\
\hline $\begin{array}{l}\text { You would like your parents/caregiver to be } \\
\text { more involved in your current education? } \\
\text { (Q10) }\end{array}$ & .817 & \\
\hline $\begin{array}{l}\text { You have many friends within this school? } \\
\text { (Q16) }\end{array}$ & .727 & \\
\hline $\begin{array}{l}\text { Your parents/caregiver are very involved in } \\
\text { your education? (Q9) }\end{array}$ & .679 & \\
\hline $\begin{array}{l}\text { You feel that you receive more guidance at } \\
\text { this school compared to your previous } \\
\text { school? (Q22) }\end{array}$ & .575 & \\
\hline $\begin{array}{l}\text { You put in more time doing your schoolwork } \\
\text { at this continuation school than you did at } \\
\text { your previous school? (Q18) }\end{array}$ & .536 & -.445 \\
\hline $\begin{array}{l}\text { You believe your education in this } \\
\text { continuation school is important? (Q11) }\end{array}$ & .517 & -.455 \\
\hline $\begin{array}{l}\text { Your current teachers are very supportive? } \\
\text { (Q13) }\end{array}$ & & -.976 \\
\hline $\begin{array}{l}\text { You believe that your current teachers think } \\
\text { your education is important? (Q12) }\end{array}$ & & -.893 \\
\hline $\begin{array}{l}\text { Your past teachers were very supportive? } \\
\text { (Q14) }\end{array}$ & & -.838 \\
\hline $\begin{array}{l}\text { You believe your teachers want you to } \\
\text { succeed? (Q20) }\end{array}$ & & -.788 \\
\hline $\begin{array}{l}\text { You feel good attending your current } \\
\text { continuation school? (Q15) }\end{array}$ & & -.610 \\
\hline
\end{tabular}


Table 5

Summary of Group One I.V.1 (reason for attending a continuation school) Mean, Standard Deviation, Confidence Intervals (CI), ANOVA

\begin{tabular}{|c|c|c|c|c|c|c|c|c|}
\hline & & \multirow[t]{2}{*}{$n$} & \multirow[t]{2}{*}{$M$} & \multirow[t]{2}{*}{$S D$} & \multicolumn{2}{|c|}{$\begin{array}{l}\text { 95\% Confidence Interval for } \\
\text { Mean }\end{array}$} & \multirow[t]{2}{*}{$F$} & \multirow[t]{2}{*}{ Sig. } \\
\hline & & & & & $\begin{array}{l}\text { Lower } \\
\text { Bound }\end{array}$ & $\begin{array}{l}\text { Upper } \\
\text { Bound }\end{array}$ & & \\
\hline \multirow{4}{*}{$\begin{array}{l}\text { Your parents/ } \\
\text { caregiver are very } \\
\text { involved in your } \\
\text { education? (Q9) }\end{array}$} & Discipline Issues & 25 & 1.68 & 1.108 & 1.22 & 2.14 & .151 & .86 \\
\hline & Credit Recovery & 32 & 1.81 & 1.091 & 1.42 & 2.21 & & \\
\hline & Both & 5 & 1.60 & .894 & .49 & 2.71 & & \\
\hline & Total & 62 & 1.74 & 1.070 & 1.47 & 2.01 & & \\
\hline \multirow{4}{*}{$\begin{array}{l}\text { You would like your } \\
\text { parents/caregiver to } \\
\text { be more involved in } \\
\text { your current } \\
\text { education? (Q10) }\end{array}$} & Discipline Issues & 25 & 2.08 & 1.115 & 1.62 & 2.54 & .232 & .79 \\
\hline & Credit Recovery & 32 & 2.22 & 1.039 & 1.84 & 2.59 & & \\
\hline & Both & 5 & 2.40 & 1.140 & .98 & 3.82 & & \\
\hline & Total & 62 & 2.18 & 1.064 & 1.91 & 2.45 & & \\
\hline \multirow{4}{*}{$\begin{array}{l}\text { You believe your } \\
\text { education in this } \\
\text { continuation school } \\
\text { is important? (Q11) }\end{array}$} & Discipline Issues & 25 & 1.84 & .898 & 1.47 & 2.21 & 2.107 & .13 \\
\hline & Credit Recovery & 32 & 1.47 & .567 & 1.26 & 1.67 & & \\
\hline & Both & 5 & 1.40 & .548 & .72 & 2.08 & & \\
\hline & Total & 62 & 1.61 & .732 & 1.43 & 1.80 & & \\
\hline \multirow{4}{*}{$\begin{array}{l}\text { You have many } \\
\text { friends within this } \\
\text { school? (Q16) }\end{array}$} & Discipline Issues & 25 & 2.60 & 1.118 & 2.14 & 3.06 & .971 & .39 \\
\hline & Credit Recovery & 32 & 2.19 & 1.148 & 1.77 & 2.60 & & \\
\hline & Both & 5 & 2.60 & 1.517 & .72 & 4.48 & & \\
\hline & Total & 62 & 2.39 & 1.164 & 2.09 & 2.68 & & \\
\hline \multirow{4}{*}{$\begin{array}{l}\text { You have many } \\
\text { friends outside of } \\
\text { this school? (Q17) }\end{array}$} & Discipline Issues & 25 & 1.56 & .712 & 1.27 & 1.85 & .456 & .63 \\
\hline & Credit Recovery & 32 & 1.56 & .914 & 1.23 & 1.89 & & \\
\hline & Both & 5 & 1.20 & .447 & .64 & 1.76 & & \\
\hline & Total & 62 & 1.53 & .804 & 1.33 & 1.74 & & \\
\hline \multirow{4}{*}{$\begin{array}{l}\text { You put in more time } \\
\text { doing your } \\
\text { schoolwork at this } \\
\text { continuation school } \\
\text { than you did at your } \\
\text { previous school?* } \\
\text { (Q18) }\end{array}$} & Discipline Issues & 25 & 2.32 & 1.406 & 1.74 & 2.90 & 1.61 & .24 \\
\hline & Credit Recovery & 32 & 1.72 & .958 & 1.37 & 2.06 & & \\
\hline & Both & 5 & 1.80 & .837 & .76 & 2.84 & & \\
\hline & Total & 62 & 1.97 & 1.173 & 1.67 & 2.27 & & \\
\hline \multirow{4}{*}{$\begin{array}{l}\text { You believe you will } \\
\text { be well prepared for } \\
\text { college or work after } \\
\text { you graduate from } \\
\text { high school? (Q19) }\end{array}$} & Discipline Issues & 25 & 1.72 & .737 & 1.42 & 2.02 & .151 & .86 \\
\hline & Credit Recovery & 32 & 1.84 & .920 & 1.51 & 2.18 & & \\
\hline & Both & 5 & 1.80 & .837 & .76 & 2.84 & & \\
\hline & Total & 62 & 1.79 & .832 & 1.58 & 2.00 & & \\
\hline \multirow{4}{*}{$\begin{array}{l}\text { You feel that you } \\
\text { receive more } \\
\text { guidance at this } \\
\text { school compared to } \\
\text { your previous } \\
\text { school? (Q22) }\end{array}$} & Discipline Issues & 25 & 2.36 & 1.150 & 1.89 & 2.83 & .522 & .60 \\
\hline & Credit Recovery & 30 & 2.37 & 1.245 & 1.90 & 2.83 & & \\
\hline & Both & 5 & 1.80 & .837 & .76 & 2.84 & & \\
\hline & Total & 60 & 2.32 & 1.172 & 2.01 & 2.62 & & \\
\hline
\end{tabular}

Note. Minimum and Maximum levels are based on the 5-point Likert scale (1- Strongly Agree to 5- Strongly Disagree).

$\mathrm{M}=$ Mean; $\mathrm{SD}=$ Standard Deviation; $\mathrm{CI}=$ Confidence Interval .

No statistical significance displayed for these variables through the ANOVA/Games-Howell. *Variable did not meet Levene's test for Homogeneity of Variance $p<.05$ - Welch $F$ and sig. reported; Kruskal-Wallis test performed. See Table 6. 
Table 6

Summary of Kruskal-Wallis Test Statistics for Q18 and I.V.1 (reason for attending a continuation school)

\begin{tabular}{l|c}
\hline & $\begin{array}{c}\text { You put in more time doing your school work at } \\
\text { this continuation school than you did at your } \\
\text { previous school? (Q18) }\end{array}$ \\
\hline$H$ & 2.639 \\
df & 2 \\
Asymp. Sig. & .267 \\
\hline
\end{tabular}

Note. ${ }^{*}$ Kruskal-Wallis Statistic $=\mathrm{H}$ as reported here (in SPSS reported as Chi-Square; Field, 2005) 
Table 7

Summary of Group One I.V.2 (previous school attended) Mean, Standard Deviation, Confidence Intervals (CI), ANOVA

\begin{tabular}{|c|c|c|c|c|c|c|c|c|}
\hline & \multirow[t]{2}{*}{ I.V. } & \multirow[t]{2}{*}{$n$} & \multirow[t]{2}{*}{$M$} & \multirow[t]{2}{*}{$\begin{array}{l}\text { Std. } \\
\text { Dev. }\end{array}$} & \multicolumn{2}{|c|}{$\begin{array}{l}95 \% \text { Confidence } \\
\text { Interval for Mean }\end{array}$} & \multirow[t]{2}{*}{$F$} & \multirow[t]{2}{*}{ Sig. } \\
\hline & & & & & $\begin{array}{l}\text { Lower } \\
\text { Bound }\end{array}$ & $\begin{array}{l}\text { Upper } \\
\text { Bound }\end{array}$ & & \\
\hline \multirow{5}{*}{$\begin{array}{l}\text { Your } \\
\text { parents/caregi } \\
\text { ver are very } \\
\text { involved in } \\
\text { your } \\
\text { education?** } \\
\text { (Q9) }\end{array}$} & Traditional Public School & 42 & 1.81 & 1.065 & 1.48 & 2.14 & .726 & .54 \\
\hline & Non-public School & 5 & 1.40 & .894 & .29 & 2.51 & & \\
\hline & Continuation School & 12 & 1.83 & 1.267 & 1.03 & 2.64 & & \\
\hline & $\begin{array}{l}\text { Other Alternative } \\
\text { Education Setting }\end{array}$ & 3 & 1.00 & .000 & 1.00 & 1.00 & & \\
\hline & Total & 62 & 1.74 & 1.070 & 1.47 & 2.01 & & \\
\hline \multirow{5}{*}{$\begin{array}{l}\text { You would like } \\
\text { your } \\
\text { parents/caregi } \\
\text { ver to be more } \\
\text { involved in } \\
\text { your current } \\
\text { education? } \\
\text { (Q10) }\end{array}$} & Traditional Public School & 42 & 2.29 & 1.088 & 1.95 & 2.62 & .521 & .67 \\
\hline & Non-public School & 5 & 2.00 & .707 & 1.12 & 2.88 & & \\
\hline & Continuation School & 12 & 2.00 & 1.128 & 1.28 & 2.72 & & \\
\hline & $\begin{array}{l}\text { Other Alternative } \\
\text { Education Setting }\end{array}$ & 3 & 1.67 & 1.155 & -1.20 & 4.54 & & \\
\hline & Total & 62 & 2.18 & 1.064 & 1.91 & 2.45 & & \\
\hline \multirow{5}{*}{$\begin{array}{l}\text { You believe } \\
\text { your education } \\
\text { in this } \\
\text { continuation } \\
\text { school is } \\
\text { important?** } \\
\text { (Q11) }\end{array}$} & Traditional Public School & 42 & 1.60 & .767 & 1.36 & 1.83 & 1.076 & .37 \\
\hline & Non-public School & 5 & 1.60 & .548 & .92 & 2.28 & & \\
\hline & Continuation School & 12 & 1.83 & .718 & 1.38 & 2.29 & & \\
\hline & $\begin{array}{l}\text { Other Alternative } \\
\text { Education Setting }\end{array}$ & 3 & 1.00 & .000 & 1.00 & 1.00 & & \\
\hline & Total & 62 & 1.61 & .732 & 1.43 & 1.80 & & \\
\hline \multirow{5}{*}{$\begin{array}{l}\text { You have } \\
\text { many friends } \\
\text { within this } \\
\text { school? (Q16) }\end{array}$} & Traditional Public School & 42 & 2.38 & 1.229 & 2.00 & 2.76 & 1.053 & .38 \\
\hline & Non-public School & 5 & 2.40 & .548 & 1.72 & 3.08 & & \\
\hline & Continuation School & 12 & 2.67 & 1.155 & 1.93 & 3.40 & & \\
\hline & $\begin{array}{l}\text { Other Alternative } \\
\text { Education Setting }\end{array}$ & 3 & 1.33 & .577 & -.10 & 2.77 & & \\
\hline & Total & 62 & 2.39 & 1.164 & 2.09 & 2.68 & & \\
\hline \multirow{5}{*}{$\begin{array}{l}\text { You have } \\
\text { many friends } \\
\text { outside of this } \\
\text { school? } \text { ? }^{\star^{\mathrm{a}}} \\
\text { (Q17) }\end{array}$} & Traditional Public School & 42 & 1.50 & .741 & 1.27 & 1.73 & 1.070 & .37 \\
\hline & Non-public School & 5 & 1.40 & .548 & .72 & 2.08 & & \\
\hline & Continuation School & 12 & 1.83 & 1.115 & 1.13 & 2.54 & & \\
\hline & $\begin{array}{l}\text { Other Alternative } \\
\text { Education Setting }\end{array}$ & 3 & 1.00 & .000 & 1.00 & 1.00 & & \\
\hline & Total & 62 & 1.53 & .804 & 1.33 & 1.74 & & \\
\hline \multirow{5}{*}{$\begin{array}{l}\text { You put in } \\
\text { more time } \\
\text { doing your } \\
\text { school work at } \\
\text { this } \\
\text { continuation } \\
\text { school than } \\
\text { you did at your } \\
\text { previous } \\
\text { school? } \\
\text { (Q18) }\end{array}$} & Traditional Public School & 42 & 1.90 & 1.206 & 1.53 & 2.28 & 1.190 & .32 \\
\hline & Non-public School & 5 & 2.40 & 1.140 & .98 & 3.82 & & \\
\hline & Continuation School & 12 & 2.25 & 1.138 & 1.53 & 2.97 & & \\
\hline & $\begin{array}{l}\text { Other Alternative } \\
\text { Education Setting }\end{array}$ & 3 & 1.00 & .000 & 1.00 & 1.00 & & \\
\hline & Total & 62 & 1.97 & 1.173 & 1.67 & 2.27 & & \\
\hline \multirow{5}{*}{$\begin{array}{l}\text { You believe } \\
\text { you will be well } \\
\text { prepared for } \\
\text { college or work } \\
\text { after you } \\
\text { graduate from } \\
\text { high school? } \\
\text { (Q19) }\end{array}$} & Traditional Public School & 42 & 1.83 & .794 & 1.59 & 2.08 & 1.605 & .20 \\
\hline & Non-public School & 5 & 1.40 & .548 & .72 & 2.08 & & \\
\hline & Continuation School & 12 & 2.00 & 1.044 & 1.34 & 2.66 & & \\
\hline & $\begin{array}{l}\text { Other Alternative } \\
\text { Education Setting }\end{array}$ & 3 & 1.00 & .000 & 1.00 & 1.00 & & \\
\hline & Total & 62 & 1.79 & .832 & 1.58 & 2.00 & & \\
\hline
\end{tabular}

(continued) 
Table 7

Summary of Group One I.V.2 (previous school attended) Mean, Standard Deviation, Confidence Intervals (CI), ANOVA (continued)

\begin{tabular}{|c|c|c|c|c|c|c|c|c|}
\hline \multirow{7}{*}{$\begin{array}{l}\text { You feel that } \\
\text { you receive } \\
\text { more guidance } \\
\text { at this school } \\
\text { compared to } \\
\text { your previous } \\
\text { school? (Q22) }\end{array}$} & \multirow[t]{2}{*}{ I.V. } & \multirow[t]{2}{*}{$n$} & \multirow[t]{2}{*}{$M$} & \multirow[t]{2}{*}{$\begin{array}{l}\text { Std. } \\
\text { Dev. }\end{array}$} & \multicolumn{2}{|c|}{$\begin{array}{l}95 \% \text { Confidence } \\
\text { Interval for Mean }\end{array}$} & \multirow[t]{2}{*}{$F$} & \multirow[t]{2}{*}{ Sig } \\
\hline & & & & & $\begin{array}{l}\text { Lower } \\
\text { Bound }\end{array}$ & $\begin{array}{l}\text { Upper } \\
\text { Bound }\end{array}$ & & \\
\hline & Traditional Public School & $\overline{41}$ & 2.34 & 1.217 & 1.96 & 2.73 & .760 & .52 \\
\hline & Non-public School & 5 & 2.40 & .548 & 1.72 & 3.08 & & \\
\hline & Continuation School & 11 & 2.45 & 1.293 & 1.59 & 3.32 & & \\
\hline & $\begin{array}{l}\text { Other Alternative } \\
\text { Education Setting }\end{array}$ & 3 & 1.33 & .577 & -.10 & 2.77 & & \\
\hline & Total & 60 & 2.32 & 1.172 & 2.01 & 2.62 & & \\
\hline
\end{tabular}


Table 8

Summary of Kruskal-Wallis Test Statistics for Q17 and I.V.2 (previous school attended)

\begin{tabular}{l|c}
\hline & You have many friends outside of this school? (Q17) \\
\hline$H$ & 3.913 \\
df & 3 \\
Asymp. Sig. & .271 \\
\hline Note. ${ }^{*}$ Kruskal-Wallis Statistic $=\mathrm{H}$ as reported here (in SPSS reported as Chi-Square; Field, 2005)
\end{tabular}

Note. ${ }^{*}$ Kruskal-Wallis Statistic $=\mathrm{H}$ as reported here (in SPSS reported as Chi-Square; Field, 2005) 
Table 9

Summary of Group One I.V.3 Mean, Standard Deviation, Confidence Intervals (CI), ANOVA

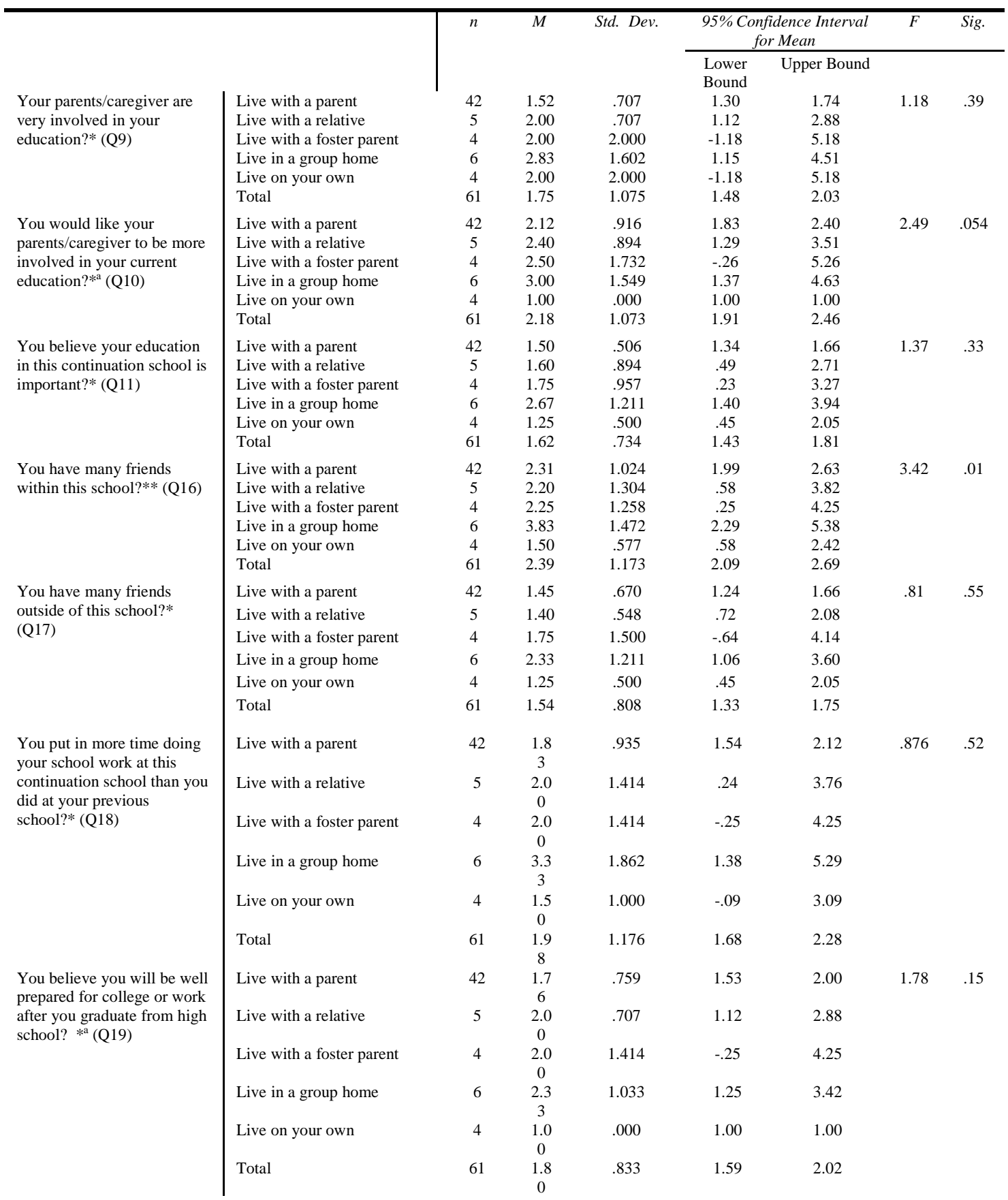


Table 9

Summary of Group One I.V.3 Mean, Standard Deviation, Confidence Intervals (CI), ANOVA (continued)

\begin{tabular}{|c|c|c|c|c|c|c|c|c|}
\hline \multirow{8}{*}{$\begin{array}{l}\text { You feel that you receive } \\
\text { more guidance at this } \\
\text { school compared to your } \\
\text { previous school? (Q22) }\end{array}$} & & \multirow[t]{2}{*}{$n$} & \multirow[t]{2}{*}{$M$} & \multirow[t]{2}{*}{ Std. Dev. } & \multicolumn{2}{|c|}{$\begin{array}{l}95 \% \text { Confidence Interval } \\
\text { for Mean }\end{array}$} & $F$ & Sig. \\
\hline & & & & & $\begin{array}{l}\text { Lower } \\
\text { Bound }\end{array}$ & Upper Bound & & \\
\hline & Live with a parent & 40 & $\begin{array}{c}2.2 \\
3\end{array}$ & 1.097 & 1.87 & 2.58 & $\begin{array}{c}1.4 \\
9\end{array}$ & .22 \\
\hline & Live with a relative & 5 & $\begin{array}{c}2.2 \\
0\end{array}$ & 1.304 & .58 & 3.82 & & \\
\hline & Live with a foster parent & 4 & $\begin{array}{c}2.5 \\
0\end{array}$ & 1.732 & -.26 & 5.26 & & \\
\hline & Live in a group home & 6 & $\begin{array}{c}3.3 \\
3\end{array}$ & 1.211 & 2.06 & 4.60 & & \\
\hline & Live on your own & 4 & $\begin{array}{c}1.7 \\
5\end{array}$ & 957 & .23 & 3.27 & & \\
\hline & Total & 59 & $\begin{array}{c}2.3 \\
2\end{array}$ & 1.181 & 2.01 & 2.63 & & \\
\hline
\end{tabular}

Note. Minimum and Maximum levels are based on the 5-point Likert scale (1- Strongly Agree to 5- Strongly Disagree). M = Mean; Std. Dev. = Standard Deviation. *Variable did not meet Levene's test for Homogeneity of Variance $p<.05$ - Welch $F$ and sig. reported; Kruskal-Wallis test performed. See Table 10-12. **Statistical significance observed with Games-Howell test at $p<.001$. ${ }^{a}$ Welch $F$ not reported- no variance found. 
Table 10

Summary of Kruskal-Wallis Test Statistics for Q10 and I.V.3 (living situation)

\begin{tabular}{l|c}
\hline & $\begin{array}{c}\text { You would like your parents/caregiver to be } \\
\text { more involved in your current education? } \\
(\text { Q10) }\end{array}$ \\
\hline$H$ & 2.297 \\
df & 3 \\
Asymp. Sig. & .513 \\
\hline
\end{tabular}

Note. $*$ Kruskal-Wallis Statistic $=\mathrm{H}$ as reported here (in SPSS reported as Chi-Square; Field 2005) 


\section{Table 11}

Summary of Kruskal-Wallis Test Statistics for Q19 and I.V.3 (living situation)

\begin{tabular}{l|c}
\hline & $\begin{array}{c}\text { You believe your will be well prepared for college or work after you } \\
\text { graduate from high school? (Q19) }\end{array}$ \\
\hline$H$ & 2.564 \\
df & 3 \\
Asymp. Sig. & .464 \\
\hline \multicolumn{2}{l|}{ Note. ${ }^{*}$ Kruskal-Wallis Statistic $=\mathrm{H}$ as reported here (in SPSS reported as Chi-Square; Field 2005) } \\
\hline
\end{tabular}


Table 12

Summary of Kruskal-Wallis Test Statistics for Q9, Q10, Q11, Q17, Q18 and I.V.3 (living situation)

\begin{tabular}{l|ccccc}
\hline & $\begin{array}{c}\text { Your } \\
\text { parents/caregiver } \\
\text { are very involved in } \\
\text { your education? } \\
\text { (Q9) }\end{array}$ & $\begin{array}{c}\text { You would like your } \\
\text { parents/caregiver } \\
\text { to be more involved } \\
\text { in your current } \\
\text { education? (Q10) }\end{array}$ & $\begin{array}{c}\text { You believe your } \\
\text { education in this } \\
\text { continuation } \\
\text { school is } \\
\text { important?(Q11) }\end{array}$ & $\begin{array}{c}\text { You have many } \\
\text { friends outside } \\
\text { of this } \\
\text { school?(Q17) }\end{array}$ & $\begin{array}{c}\text { You put in more time } \\
\text { doing your school } \\
\text { work at this } \\
\text { continuation school } \\
\text { than you did at your } \\
\text { previous } \\
\text { school?(Q18) }\end{array}$ \\
\hline$H$ & 6.140 & 2.297 & 6.524 & 3.913 & 4.252 \\
df & 3 & 3 & 3 & 3 & 3 \\
Asymp. Sig. & .105 & .513 & .089 & .271 & .235 \\
\hline
\end{tabular}

Note.* Kruskal-Wallis Statistic $=\mathrm{H}$ as reported here (in SPSS reported as Chi-Square; Field, 2005) 
Table 13

Summary of Group One I.V.4 (current grade enrolled) Mean, Standard Deviation, Confidence Intervals (CI), ANOVA

\begin{tabular}{|c|c|c|c|c|c|c|c|c|}
\hline & \multirow[t]{2}{*}{ I.V. } & \multirow[t]{2}{*}{$n$} & \multirow[t]{2}{*}{$M$} & \multirow[t]{2}{*}{$\begin{array}{l}\text { Std. } \\
\text { Dev. }\end{array}$} & \multicolumn{2}{|c|}{$\begin{array}{l}95 \% \text { Confidence } \\
\text { Interval for Mean }\end{array}$} & \multirow[t]{2}{*}{$F$} & \multirow[t]{2}{*}{ Sig } \\
\hline & & & & & $\begin{array}{l}\text { Lower } \\
\text { Bound }\end{array}$ & $\begin{array}{l}\text { Upper } \\
\text { Bound }\end{array}$ & & \\
\hline \multirow{5}{*}{$\begin{array}{l}\text { Your parents/caregiver are very } \\
\text { involved in your education? }{ }^{* a}(\mathrm{Q} 9)\end{array}$} & 9th & 7 & 1.00 & .000 & 1.00 & 1.00 & 1.83 & .15 \\
\hline & 10th & 13 & 2.15 & 1.345 & 1.34 & 2.97 & & \\
\hline & 11th & 23 & 1.78 & .998 & 1.35 & 2.21 & & \\
\hline & 12th & 18 & 1.72 & 1.074 & 1.19 & 2.26 & & \\
\hline & Total & 61 & 1.75 & 1.075 & 1.48 & 2.03 & & \\
\hline \multirow{5}{*}{$\begin{array}{l}\text { You would like your parents/caregiver } \\
\text { to be more involved in your current } \\
\text { education? (Q10) }\end{array}$} & 9th & 7 & 1.57 & .535 & 1.08 & 2.07 & .982 & .41 \\
\hline & 10th & 13 & 2.38 & 1.387 & 1.55 & 3.22 & & \\
\hline & 11th & 23 & 2.22 & .998 & 1.79 & 2.65 & & \\
\hline & 12th & 18 & 2.28 & 1.018 & 1.77 & 2.78 & & \\
\hline & Total & 61 & 2.20 & 1.062 & 1.92 & 2.47 & & \\
\hline \multirow{5}{*}{$\begin{array}{l}\text { You believe your education in this } \\
\text { continuation school is important?* } \\
\text { (Q11) }\end{array}$} & 9th & 7 & 1.29 & .488 & .83 & 1.74 & 1.33 & .29 \\
\hline & 10th & 13 & 1.92 & 1.115 & 1.25 & 2.60 & & \\
\hline & 11th & 23 & 1.65 & .647 & 1.37 & 1.93 & & \\
\hline & 12th & 18 & 1.50 & .514 & 1.24 & 1.76 & & \\
\hline & Total & 61 & 1.62 & .734 & 1.43 & 1.81 & & \\
\hline \multirow{5}{*}{$\begin{array}{l}\text { You have many friends within this } \\
\text { school?* (Q16) }\end{array}$} & 9th & 7 & 2.14 & .378 & 1.79 & 2.49 & .88 & .46 \\
\hline & 10th & 13 & 2.85 & 1.519 & 1.93 & 3.76 & & \\
\hline & 11 th & 23 & 2.35 & 1.071 & 1.88 & 2.81 & & \\
\hline & 12th & 18 & 2.28 & 1.179 & 1.69 & 2.86 & & \\
\hline & Total & 61 & 2.41 & 1.160 & 2.11 & 2.71 & & \\
\hline \multirow{5}{*}{$\begin{array}{l}\text { You have many friends outside of this } \\
\text { school? (Q17) }\end{array}$} & 9th & 7 & 1.14 & .378 & .79 & 1.49 & 1.28 & .59 \\
\hline & 10th & 13 & 1.62 & .768 & 1.15 & 2.08 & & \\
\hline & 11th & 23 & 1.57 & .945 & 1.16 & 1.97 & & \\
\hline & 12th & 18 & 1.61 & .778 & 1.22 & 2.00 & & \\
\hline & Total & 61 & 1.54 & .808 & 1.33 & 1.75 & & \\
\hline \multirow{5}{*}{$\begin{array}{l}\text { You put in more time doing your } \\
\text { school work at this continuation school } \\
\text { than you did at your previous school?* } \\
\text { (Q18) }\end{array}$} & 9th & 7 & 1.43 & .787 & .70 & 2.16 & 1.69 & .20 \\
\hline & 10th & 13 & 2.69 & 1.702 & 1.66 & 3.72 & & \\
\hline & 11th & 23 & 1.91 & .949 & 1.50 & 2.32 & & \\
\hline & 12th & 18 & 1.78 & .943 & 1.31 & 2.25 & & \\
\hline & Total & 61 & 1.98 & 1.176 & 1.68 & 2.28 & & \\
\hline \multirow{5}{*}{$\begin{array}{l}\text { You believe you will be well prepared } \\
\text { for college or work after you graduate } \\
\text { from high school? (Q19) }\end{array}$} & 9th & 7 & 1.14 & .378 & .79 & 1.49 & 3.79 & .14 \\
\hline & 10th & 13 & 1.85 & .801 & 1.36 & 2.33 & & \\
\hline & 11th & 23 & 1.83 & .834 & 1.47 & 2.19 & & \\
\hline & 12th & 18 & 2.00 & .907 & 1.55 & 2.45 & & \\
\hline & Total & 61 & 1.80 & .833 & 1.59 & 2.02 & & \\
\hline
\end{tabular}

(continued) 
Table 13

Summary of Group One I.V.4 (current grade enrolled) Mean, Standard Deviation, Confidence Intervals (CI), ANOVA (continued)

\begin{tabular}{|c|c|c|c|c|c|c|c|c|}
\hline \multirow{7}{*}{$\begin{array}{l}\text { You feel that you receive more } \\
\text { guidance at this school compared to } \\
\text { your previous school?* (Q22) }\end{array}$} & \multirow[t]{2}{*}{ I.V. } & \multirow[t]{2}{*}{$n$} & \multirow[t]{2}{*}{$M$} & \multirow[t]{2}{*}{$\begin{array}{l}\text { Std. } \\
\text { Dev. }\end{array}$} & \multicolumn{2}{|c|}{$\begin{array}{l}\text { 95\% Confidence } \\
\text { Interval for Mean }\end{array}$} & \multirow[t]{2}{*}{$F$} & \multirow[t]{2}{*}{ Sig } \\
\hline & & & & & $\begin{array}{l}\text { Lower } \\
\text { Bound }\end{array}$ & $\begin{array}{l}\text { Upper } \\
\text { Bound }\end{array}$ & & \\
\hline & 9th & 7 & 2.00 & .577 & 1.47 & 2.53 & .66 & .58 \\
\hline & 10th & 13 & 2.54 & 1.330 & 1.73 & 3.34 & & \\
\hline & 11 th & 23 & 2.30 & 1.105 & 1.83 & 2.78 & & \\
\hline & 12th & 16 & 2.38 & 1.360 & 1.65 & 3.10 & & \\
\hline & Total & 59 & 2.34 & 1.169 & 2.03 & 2.64 & & \\
\hline
\end{tabular}

Note. Minimum and Maximum levels are based on the 5-point Likert scale (1- Strongly Agree to 5- Strongly Disagree). *Variable did not meet Levene's test for Homogeneity of Variance $p<.05$ - Welch $F$ and sig. reported; Kruskal-Wallis test performed. See Table14 \& $15 .{ }^{\text {a }}$ Welch $F$ not reported- no variance found. 
Table 14

Summary of Kruskal-Wallis Test Statistics for Q9 and I.V.4 (current grade enrolled)

\begin{tabular}{l|c}
\hline & $\begin{array}{c}\text { Your parents/caregiver are very involved in } \\
\text { your education? }(Q 9)\end{array}$ \\
\hline$H$ & 6.481 \\
df & 3 \\
Asymp. Sig. & .090 \\
\hline
\end{tabular}

Note. $*$ Kruskal-Wallis Statistic $=\mathrm{H}$ as reported here (in SPSS reported as Chi-Square; Field, 2005) 
Table 15

Summary of Kruskal-Wallis Test Statistics for Q11, Q16, Q18, and Q22 and I.V.4 (current grade enrolled)

\begin{tabular}{l|cccc}
\hline & $\begin{array}{c}\text { You believe your } \\
\text { education in this } \\
\text { continuation school is } \\
\text { important? (Q11) }\end{array}$ & $\begin{array}{c}\text { You have many } \\
\text { friends within this } \\
\text { school? (Q16) }\end{array}$ & $\begin{array}{c}\text { You put in more } \\
\text { time doing your } \\
\text { school work at this } \\
\text { continuation school } \\
\text { than you did at } \\
\text { our previous } \\
\text { school? (Q18) }\end{array}$ & $\begin{array}{c}\text { You feel that you } \\
\text { receive more guidance } \\
\text { at this school } \\
\text { compared to your } \\
\text { previous school? } \\
\text { (Q22) }\end{array}$ \\
\hline df & 2.505 & 1.660 & 4.124 & .685 \\
Asymp. Sig. & 3 & 3 & 3 & 3 \\
\hline Note* Kruskal-Wallis Statistic $=\mathrm{H}$ as & .474 & .646 & .248 & .877 \\
\hline
\end{tabular}

Note. ${ }^{*}$ Kruskal-Wallis Statistic $=\mathrm{H}$ as reported here (in SPSS reported as Chi-Square; Field, 2005) 
Table 16

Summary of Group One I.V.5 (type of continuation school attended) Mean, Standard Deviation, Confidence Intervals (CI), ANOVA

\begin{tabular}{|c|c|c|c|c|c|c|c|c|}
\hline & \multirow[t]{2}{*}{ I.V. } & \multirow[t]{2}{*}{$n$} & \multirow[t]{2}{*}{$M$} & \multirow[t]{2}{*}{$\begin{array}{l}\text { Std. } \\
\text { Dev. }\end{array}$} & \multicolumn{2}{|c|}{$\begin{array}{l}\text { 95\% Confidence } \\
\text { Interval for Mean }\end{array}$} & \multirow[t]{2}{*}{$F$} & \multirow[t]{2}{*}{ Sig. } \\
\hline & & & & & $\begin{array}{l}\text { Lower } \\
\text { Bound }\end{array}$ & $\begin{array}{l}\text { Upper } \\
\text { Bound }\end{array}$ & & \\
\hline \multirow{3}{*}{$\begin{array}{l}\text { Your parents/caregiver } \\
\text { are very involved in your } \\
\text { education? (Q9) }\end{array}$} & Traditional & 25 & 2.00 & 1.155 & 1.52 & 2.48 & 2.49 & .12 \\
\hline & Non-traditional & 37 & 1.57 & .987 & 1.24 & 1.90 & & \\
\hline & Total & 62 & 1.74 & 1.070 & 1.47 & 2.01 & & \\
\hline \multirow{3}{*}{$\begin{array}{l}\text { You would like your } \\
\text { parents/caregiver to be } \\
\text { more involved in your } \\
\text { current education? } \\
\text { (Q10) }\end{array}$} & Traditional & 25 & 2.44 & 1.083 & 1.99 & 2.89 & 2.6 & .11 \\
\hline & Non-traditional & 37 & 2.00 & 1.027 & 1.66 & 2.34 & & \\
\hline & Total & 62 & 2.18 & 1.064 & 1.91 & 2.45 & & \\
\hline \multirow{3}{*}{$\begin{array}{l}\text { You believe your } \\
\text { education in this } \\
\text { continuation school is } \\
\text { important? (Q11) }\end{array}$} & Traditional & 25 & 1.48 & .586 & 1.24 & 1.72 & 1.34 & .24 \\
\hline & Non-traditional & 37 & 1.70 & .812 & 1.43 & 1.97 & & \\
\hline & Total & 62 & 1.61 & .732 & 1.43 & 1.80 & & \\
\hline \multirow{3}{*}{$\begin{array}{l}\text { You have many friends } \\
\text { within this school?* } \\
\text { (Q16) }\end{array}$} & Traditional & 25 & 2.36 & 1.350 & 1.80 & 2.92 & .022 & .88 \\
\hline & Non-traditional & 37 & 2.41 & 1.040 & 2.06 & 2.75 & & \\
\hline & Total & 62 & 2.39 & 1.164 & 2.09 & 2.68 & & \\
\hline \multirow{3}{*}{$\begin{array}{l}\text { You have many friends } \\
\text { outside of this school?* } \\
\text { (Q17) }\end{array}$} & Traditional & 25 & 1.72 & 1.021 & 1.30 & 2.14 & 1.92 & .17 \\
\hline & Non-traditional & 37 & 1.41 & .599 & 1.21 & 1.61 & & \\
\hline & Total & 62 & 1.53 & .804 & 1.33 & 1.74 & & \\
\hline \multirow{3}{*}{$\begin{array}{l}\text { You put in more time } \\
\text { doing your school work } \\
\text { at this continuation } \\
\text { school than you did at } \\
\text { your previous school? } \\
\text { (Q18) }\end{array}$} & Traditional & 25 & 1.68 & .900 & 1.31 & 2.05 & 2.59 & .11 \\
\hline & Non-traditional & 37 & 2.16 & 1.302 & 1.73 & 2.60 & & \\
\hline & Total & 62 & 1.97 & 1.173 & 1.67 & 2.27 & & \\
\hline \multirow{3}{*}{$\begin{array}{l}\text { You believe you will be } \\
\text { well prepared for college } \\
\text { or work after you } \\
\text { graduate from high } \\
\text { school? }^{* *}(\mathrm{Q} 19)\end{array}$} & Traditional & 25 & 2.12 & .927 & 1.74 & 2.50 & 7.24 & .01 \\
\hline & Non-traditional & 37 & 1.57 & .689 & 1.34 & 1.80 & & \\
\hline & Total & 62 & 1.79 & .832 & 1.58 & 2.00 & & \\
\hline \multirow{3}{*}{$\begin{array}{l}\text { You feel that you receive } \\
\text { more guidance at this } \\
\text { school compared to your } \\
\text { previous school?* (Q22) }\end{array}$} & Traditional & 23 & 2.39 & 1.406 & 1.78 & 3.00 & .129 & .72 \\
\hline & Non-traditional & 37 & 2.27 & 1.018 & 1.93 & 2.61 & & \\
\hline & Total & 60 & 2.32 & 1.172 & 2.01 & 2.62 & & \\
\hline
\end{tabular}

Note. Minimum and Maximum levels are based on the 5-point Likert scale (1- Strongly Agree to 5- Strongly Disagree). *Variable did not meet Levene's test for Homogeneity of Variance $p<.05$ - Welch $F$ and sig. reported; Kruskal-Wallis test performed. See Table 17. **Statistical Significance at $p<.05$. 
Table 17

Summary of Kruskal-Wallis Test Statistics for Q16, Q17, and Q22 and I.V.5 (type of continuation school attended)

\begin{tabular}{l|ccc}
\hline & $\begin{array}{c}\text { You have many friends within } \\
\text { this school?(Q16) }\end{array}$ & $\begin{array}{c}\text { You have many friends } \\
\text { outside of this school? } \\
\text { (Q17) }\end{array}$ & $\begin{array}{c}\text { You feel that you receive more guidance } \\
\text { at this school compared to your previous } \\
\text { school?(Q22) }\end{array}$ \\
\hline$H$ & .022 & .151 & .010 \\
df & 1 & 1 & 1 \\
Asymp. Sig. & .883 & .697 & .920 \\
\hline
\end{tabular}

Note. $*$ Kruskal-Wallis Statistic $=\mathrm{H}$ as reported here (in SPSS reported as Chi-Square) 
Table 18

Summary of Group Two I.V.1 (reason for attending a continuation school) Mean, Standard Deviation, Confidence Intervals (CI), ANOVA

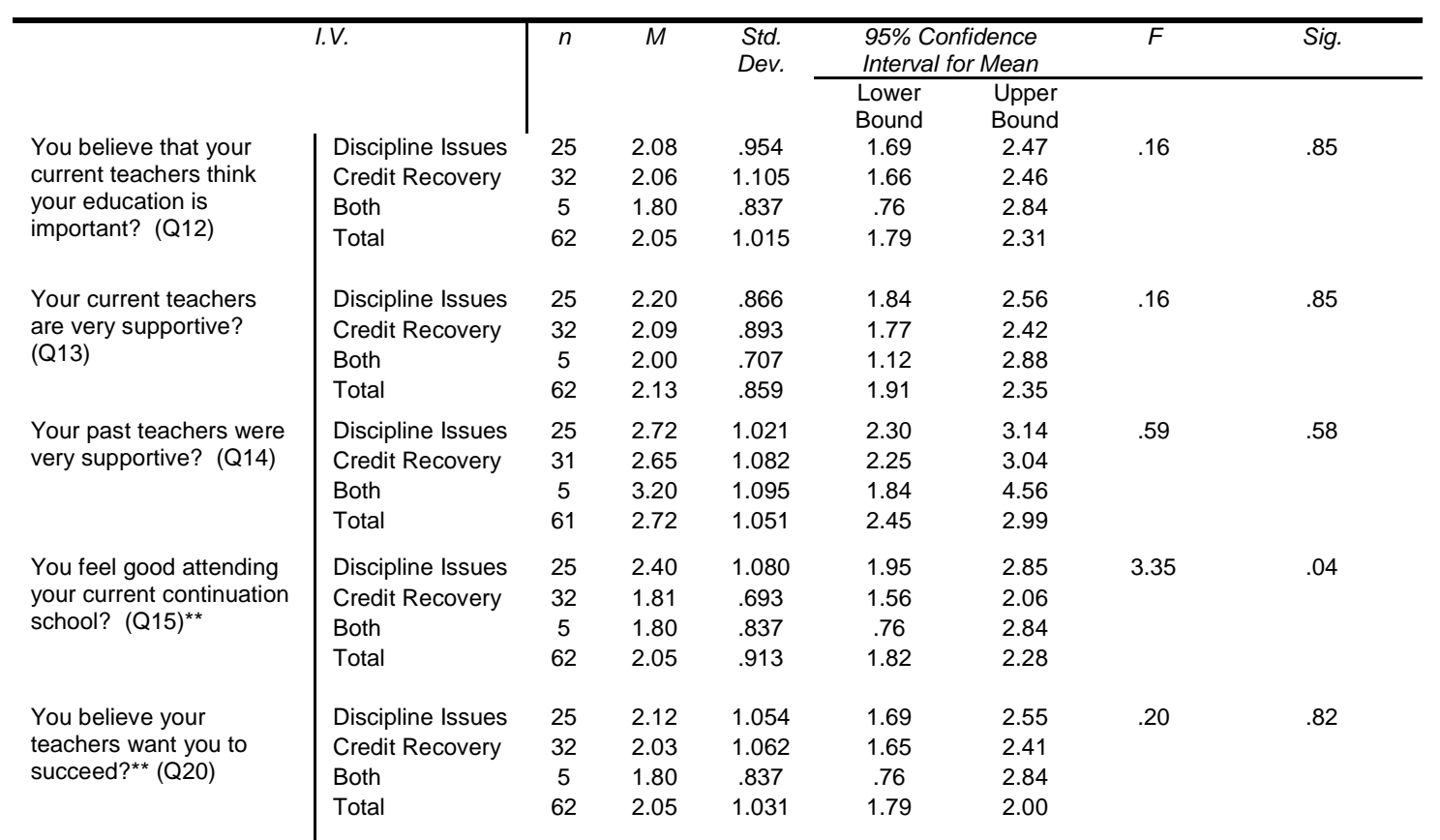

Note. Minimum and Maximum levels are based on the 5-point Likert scale (1- Strongly Agree to 5- Strongly Disagree). **Statistically significant at $p<.05$. 
Table 19

Summary of Group Two I.V.2 (previous school attended) Mean, Standard Deviation, Confidence Intervals (CI), ANOVA

\begin{tabular}{|c|c|c|c|c|c|c|c|c|}
\hline & \multirow[t]{2}{*}{ I.V. } & \multirow[t]{2}{*}{$n$} & \multirow[t]{2}{*}{$M$} & \multirow[t]{2}{*}{$\begin{array}{l}\text { Std. } \\
\text { Dev. }\end{array}$} & \multicolumn{2}{|c|}{$\begin{array}{l}\text { 95\% Confidence } \\
\text { Interval for Mean }\end{array}$} & \multirow[t]{2}{*}{$F$} & \multirow[t]{2}{*}{ Sig. } \\
\hline & & & & & $\begin{array}{l}\text { Lower } \\
\text { Bound }\end{array}$ & $\begin{array}{l}\text { Upper } \\
\text { Bound }\end{array}$ & & \\
\hline \multirow{5}{*}{$\begin{array}{l}\text { You believe that your } \\
\text { current teachers think your } \\
\text { education is important? } \\
\text { (Q12) }\end{array}$} & Traditional Public School & 42 & 2.10 & 1.122 & 1.75 & 2.44 & \multirow[t]{5}{*}{.522} & \multirow[t]{5}{*}{.67} \\
\hline & Non-public School & 5 & 2.00 & .707 & 1.12 & 2.88 & & \\
\hline & Continuation School & 12 & 2.08 & .793 & 1.58 & 2.59 & & \\
\hline & $\begin{array}{l}\text { Other Alternative } \\
\text { Education Setting }\end{array}$ & 3 & 1.33 & .577 & -.10 & 2.77 & & \\
\hline & Total & 62 & 2.05 & 1.015 & 1.79 & 2.31 & & \\
\hline \multirow{5}{*}{$\begin{array}{l}\text { your current teachers are } \\
\text { very supportive? (Q13) }\end{array}$} & Traditional Public School & 42 & 2.12 & .916 & 1.83 & 2.40 & \multirow[t]{5}{*}{1.11} & \multirow[t]{5}{*}{.35} \\
\hline & Non-public School & 5 & 2.40 & .548 & 1.72 & 3.08 & & \\
\hline & Continuation School & 12 & 2.25 & .754 & 1.77 & 2.73 & & \\
\hline & $\begin{array}{l}\text { Other Alternative } \\
\text { Education Setting }\end{array}$ & 3 & 1.33 & .577 & -.10 & 2.77 & & \\
\hline & Total & 62 & 2.13 & .859 & 1.91 & 2.35 & & \\
\hline \multirow{5}{*}{$\begin{array}{l}\text { Your past teachers were } \\
\text { very supportive? (Q14) }\end{array}$} & Traditional Public School & 41 & 2.83 & 1.116 & 2.48 & 3.18 & \multirow[t]{5}{*}{2.01} & \multirow[t]{5}{*}{.12} \\
\hline & Non-public School & 5 & 2.60 & .548 & 1.92 & 3.28 & & \\
\hline & Continuation School & 12 & 2.75 & .866 & 2.20 & 3.30 & & \\
\hline & $\begin{array}{l}\text { Other Alternative } \\
\text { Education Setting }\end{array}$ & 3 & 1.33 & .577 & -.10 & 2.77 & & \\
\hline & Total & 61 & 2.72 & 1.051 & 2.45 & 2.99 & & \\
\hline \multirow{5}{*}{$\begin{array}{l}\text { You feel good attending } \\
\text { your current continuation } \\
\text { school? (Q15) }\end{array}$} & Traditional Public School & 42 & 1.95 & .962 & 1.65 & 2.25 & \multirow[t]{5}{*}{1.75} & \multirow[t]{5}{*}{.17} \\
\hline & Non-public School & 5 & 2.40 & .548 & 1.72 & 3.08 & & \\
\hline & Continuation School & 12 & 2.42 & .793 & 1.91 & 2.92 & & \\
\hline & $\begin{array}{l}\text { Other Alternative } \\
\text { Education Setting }\end{array}$ & 3 & 1.33 & .577 & -.10 & 2.77 & & \\
\hline & Total & 62 & 2.05 & .913 & 1.82 & 2.28 & & \\
\hline \multirow{5}{*}{$\begin{array}{l}\text { You believe your teachers } \\
\text { want you to succeed? } \\
\text { (Q20) }\end{array}$} & Traditional Public School & 42 & 2.10 & 1.078 & 1.76 & 2.43 & \multirow{5}{*}{1.11} & \multirow[t]{5}{*}{.35} \\
\hline & Non-Public School & 5 & 2.20 & .837 & 1.16 & 3.24 & & \\
\hline & Continuation School & 12 & 2.08 & .996 & 1.45 & 2.72 & & \\
\hline & Other Alternative & 3 & 1.00 & .000 & 1.00 & 1.00 & & \\
\hline & $\begin{array}{l}\text { Education setting } \\
\text { Total }\end{array}$ & 62 & 2.05 & 1.031 & 1.79 & 2.31 & & \\
\hline
\end{tabular}

Note. Minimum and Maximum levels are based on the 5-point Likert scale (1- Strongly Agree to 5- Strongly Disagree). $\mathrm{M}=$ Mean; Std. Dev. = Standard Deviation. 
Table 20

Summary of Group Two I.V.3 (living situation) Mean, Standard Deviation, Confidence Intervals (CI), ANOVA

\begin{tabular}{|c|c|c|c|c|c|c|c|c|}
\hline \multicolumn{2}{|r|}{ I.V. } & $N$ & Mean & $\begin{array}{l}\text { Std. } \\
\text { Dev. }\end{array}$ & \multicolumn{2}{|c|}{$\begin{array}{l}95 \% \text { Confidence } \\
\text { Interval for Mean }\end{array}$} & $F$ & Sig. \\
\hline $\begin{array}{l}\text { You believe that your current } \\
\text { teachers think your education } \\
\text { is important? (Q12) }\end{array}$ & $\begin{array}{l}\text { Live with a parent } \\
\text { Live with a relative } \\
\text { Live with a foster parent } \\
\text { Live in a group home } \\
\text { Live on your own } \\
\text { Total }\end{array}$ & $\begin{array}{c}42 \\
5 \\
4 \\
6 \\
4 \\
61\end{array}$ & $\begin{array}{l}1.95 \\
2.00 \\
1.75 \\
3.00 \\
2.00 \\
2.05\end{array}$ & $\begin{array}{l}.909 \\
1.000 \\
.957 \\
.894 \\
2.000 \\
1.023\end{array}$ & $\begin{array}{c}\text { Lower } \\
\text { Bound } \\
1.67 \\
.76 \\
.23 \\
2.06 \\
-1.18 \\
1.79\end{array}$ & $\begin{array}{c}\text { Upper } \\
\text { Bound } \\
2.24 \\
3.24 \\
3.27 \\
3.94 \\
5.18 \\
2.31\end{array}$ & 1.53 & .21 \\
\hline $\begin{array}{l}\text { your current teachers are } \\
\text { very supportive? (Q13) }\end{array}$ & $\begin{array}{l}\text { Live with a parent } \\
\text { Live with a relative } \\
\text { Live with a foster parent } \\
\text { Live in a group home } \\
\text { Live on your own }\end{array}$ & $\begin{array}{c}42 \\
5 \\
4 \\
6 \\
4\end{array}$ & $\begin{array}{l}2.00 \\
2.40 \\
2.00 \\
2.83 \\
2.25\end{array}$ & $\begin{array}{l}.733 \\
.894 \\
.816 \\
.753 \\
1.893\end{array}$ & $\begin{array}{l}1.77 \\
1.29 \\
.70 \\
2.04 \\
-.76\end{array}$ & $\begin{array}{l}2.23 \\
3.51 \\
3.30 \\
3.62 \\
5.26\end{array}$ & 1.43 & .24 \\
\hline & Total & 61 & 2.13 & .866 & 1.91 & 2.35 & & \\
\hline $\begin{array}{l}\text { Your past teachers were very } \\
\text { supportive? (Q14) }\end{array}$ & $\begin{array}{l}\text { Live with a parent } \\
\text { Live with a relative } \\
\text { Live with a foster parent } \\
\text { Live in a group home } \\
\text { Live on your own }\end{array}$ & $\begin{array}{c}42 \\
4 \\
4 \\
6 \\
4\end{array}$ & $\begin{array}{l}2.55 \\
3.25 \\
2.75 \\
3.67 \\
2.75\end{array}$ & $\begin{array}{c}.993 \\
.957 \\
.500 \\
1.033 \\
1.708\end{array}$ & $\begin{array}{c}2.24 \\
1.73 \\
1.95 \\
2.58 \\
.03\end{array}$ & $\begin{array}{l}2.86 \\
4.77 \\
3.55 \\
4.75 \\
5.47\end{array}$ & 1.84 & .14 \\
\hline & Total & 60 & 2.73 & 1.056 & 2.46 & 3.01 & & \\
\hline $\begin{array}{l}\text { You feel good attending your } \\
\text { current continuation } \\
\text { school?** }(\mathrm{Q} 15)\end{array}$ & $\begin{array}{l}\text { Live with a parent } \\
\text { Live with a relative } \\
\text { Live with a foster parent } \\
\text { Live in a group home } \\
\text { Live on your own }\end{array}$ & $\begin{array}{c}42 \\
5 \\
4 \\
6 \\
4\end{array}$ & $\begin{array}{l}1.88 \\
2.40 \\
2.00 \\
3.33 \\
1.50\end{array}$ & $\begin{array}{c}.739 \\
1.140 \\
.816 \\
1.211 \\
.577\end{array}$ & $\begin{array}{c}1.65 \\
.98 \\
.70 \\
2.06 \\
.58\end{array}$ & $\begin{array}{l}2.11 \\
3.82 \\
3.30 \\
4.60 \\
2.42\end{array}$ & 4.77 & .001 \\
\hline & Total & 61 & 2.05 & .921 & 1.81 & 2.28 & & \\
\hline $\begin{array}{l}\text { You believe your teachers } \\
\text { want you to succeed? (Q20) }\end{array}$ & $\begin{array}{l}\text { Live with a parent } \\
\text { Live with a relative } \\
\text { Live with a foster parent } \\
\text { Live in a group home } \\
\text { Live on your own }\end{array}$ & $\begin{array}{c}42 \\
5 \\
4 \\
6 \\
4\end{array}$ & $\begin{array}{l}2.00 \\
2.00 \\
2.00 \\
2.67 \\
2.00\end{array}$ & $\begin{array}{l}.883 \\
1.000 \\
1.414 \\
1.211 \\
2.000\end{array}$ & $\begin{array}{l}1.72 \\
.76 \\
-.25 \\
1.40 \\
-1.18\end{array}$ & $\begin{array}{l}2.28 \\
3.24 \\
4.25 \\
3.94 \\
5.18\end{array}$ & .55 & .70 \\
\hline & Total & 61 & 2.07 & 1.031 & 1.80 & 2.33 & & \\
\hline
\end{tabular}

Note. Minimum and Maximum levels are based on the 5-point Likert scale (1- Strongly Agree to 5- Strongly Disagree). M = Mean; Std. Dev. = Standard Deviation. **Statistical significance observed at $p<.05$. 
Table 21

Summary of Group Two I.V.4 (grade currently enrolled) Mean, Standard Deviation, Confidence Intervals (CI), ANOVA

\begin{tabular}{|c|c|c|c|c|c|c|c|c|}
\hline & \multirow[t]{2}{*}{ I.V. } & \multirow[t]{2}{*}{$n$} & \multirow[t]{2}{*}{$M$} & \multirow{2}{*}{$\begin{array}{l}\text { Std. } \\
\text { Dev. }\end{array}$} & \multicolumn{2}{|c|}{$95 \%$ Confidence Interval for Mean } & \multirow[t]{2}{*}{$\bar{F}$} & \multirow[t]{2}{*}{ Sig. } \\
\hline & & & & & Lower Bound & Upper Bound & & \\
\hline \multirow{5}{*}{$\begin{array}{l}\text { You believe that your current } \\
\text { teachers think your education } \\
\text { is important?* }(Q 12)\end{array}$} & 9th & 7 & 1.57 & .535 & 1.08 & 2.07 & 2.03 & .14 \\
\hline & 10th & 13 & 2.31 & 1.182 & 1.59 & 3.02 & & \\
\hline & 11th & 23 & 1.87 & .757 & 1.54 & 2.20 & & \\
\hline & 12th & 18 & 2.33 & 1.237 & 1.72 & 2.95 & & \\
\hline & Total & 61 & 2.07 & 1.014 & 1.81 & 2.33 & & \\
\hline \multirow{5}{*}{$\begin{array}{l}\text { Your current teachers are very } \\
\text { supportive? (Q13) }\end{array}$} & 9th & 7 & 2.00 & .577 & 1.47 & 2.53 & .35 & .79 \\
\hline & 10th & 13 & 2.23 & 1.013 & 1.62 & 2.84 & & \\
\hline & 11th & 23 & 2.04 & .767 & 1.71 & 2.38 & & \\
\hline & 12th & 18 & 2.28 & .958 & 1.80 & 2.75 & & \\
\hline & Total & 61 & 2.15 & .853 & 1.93 & 2.37 & & \\
\hline \multirow{5}{*}{$\begin{array}{l}\text { Your past teachers were very } \\
\text { supportive?* }(\text { Q14) }\end{array}$} & 9th & 7 & 2.29 & .488 & 1.83 & 2.74 & 1.78 & .18 \\
\hline & 10th & 13 & 2.69 & 1.377 & 1.86 & 3.52 & & \\
\hline & 11th & 23 & 2.83 & 1.029 & 2.38 & 3.27 & & \\
\hline & 12th & 17 & 2.88 & .928 & 2.41 & 3.36 & & \\
\hline & Total & 60 & 2.75 & 1.035 & 2.48 & 3.02 & & \\
\hline \multirow{5}{*}{$\begin{array}{l}\text { You feel good attending your } \\
\text { current continuation school?* } \\
\text { (Q15) }\end{array}$} & 9th & 7 & 2.00 & .577 & 1.47 & 2.53 & .49 & .69 \\
\hline & 10th & 13 & 2.38 & 1.387 & 1.55 & 3.22 & & \\
\hline & 11th & 23 & 2.04 & .825 & 1.69 & 2.40 & & \\
\hline & 12th & 18 & 1.89 & .676 & 1.55 & 2.23 & & \\
\hline & Total & 61 & 2.07 & .910 & 1.83 & 2.30 & & \\
\hline \multirow{5}{*}{$\begin{array}{l}\text { You believe your teachers } \\
\text { want you to succeed? (Q20) }\end{array}$} & 9th & 7 & 1.57 & .787 & .84 & 2.30 & 1.00 & .40 \\
\hline & 10th & 13 & 2.31 & 1.182 & 1.59 & 3.02 & & \\
\hline & 11th & 23 & 1.96 & .825 & 1.60 & 2.31 & & \\
\hline & 12th & 18 & 2.22 & 1.215 & 1.62 & 2.83 & & \\
\hline & Total & 61 & 2.07 & 1.031 & 1.80 & 2.33 & & \\
\hline
\end{tabular}

Note. Minimum and Maximum levels are based on the 5-point Likert scale (1- Strongly Agree to 5- Strongly Disagree). M = Mean; Std. Dev. = Standard Deviation. *Variable did not meet Levene's test for Homogeneity of Variance $p<.05$; Kruskal-Wallis test performed. See Table 22. 
Table 22

Summary of Kruskal-Wallis Test Statistics for Q12, Q14, Q15 and I.V.4 (grade currently enrolled)

\begin{tabular}{l|ccc}
\hline & $\begin{array}{c}\text { You believe that your } \\
\text { current teachers think your } \\
\text { education is important? } \\
(Q 12)\end{array}$ & $\begin{array}{c}\text { Your past } \\
\text { teachers were } \\
\text { very supportive? } \\
(Q 14)\end{array}$ & $\begin{array}{c}\text { You feel good attending } \\
\text { your current } \\
\text { continuation school? } \\
(Q 15)\end{array}$ \\
\hline$H$ & 3.439 & 2.626 & .798 \\
df & 3 & 3 & 3 \\
Asymp. Sig. & .329 & .45 & .85 \\
\hline
\end{tabular}


Table 23

Summary of Group Two I.V.5 (type of continuation school attended) Mean, Standard Deviation, Confidence Intervals (CI), ANOVA

\begin{tabular}{|c|c|c|c|c|c|c|c|c|}
\hline \multirow{4}{*}{$\begin{array}{l}\text { You believe that your current } \\
\text { teachers think your education is } \\
\text { important? (Q12) }\end{array}$} & \multirow[t]{2}{*}{ I.V. } & \multirow[t]{2}{*}{$n$} & \multirow[t]{2}{*}{$M$} & \multirow[t]{2}{*}{$\begin{array}{l}\text { Std. } \\
\text { Dev. }\end{array}$} & \multicolumn{2}{|c|}{$\begin{array}{l}\text { 95\% Confidence } \\
\text { Interval for } \\
\text { Mean }\end{array}$} & \multirow[t]{2}{*}{$F$} & \multirow[t]{2}{*}{ Sig. } \\
\hline & & & & & $\begin{array}{l}\text { Lower } \\
\text { Bound }\end{array}$ & $\begin{array}{l}\text { Upp } \\
\text { er } \\
\text { Bou } \\
\text { nd }\end{array}$ & & \\
\hline & Traditional & 25 & 2.08 & 1.187 & 1.59 & 2.57 & .40 & .84 \\
\hline & Non-traditional & 37 & 2.03 & .897 & 1.73 & 2.33 & & \\
\hline & Total & 62 & 2.05 & 1.015 & 1.79 & 2.31 & & \\
\hline \multirow{3}{*}{$\begin{array}{l}\text { Your current teachers are very } \\
\text { supportive? (Q13) }\end{array}$} & Traditional & 25 & 2.08 & .954 & 1.69 & 2.47 & .14 & .72 \\
\hline & Non-traditional & 37 & 2.16 & .800 & 1.90 & 2.43 & & \\
\hline & Total & 62 & 2.13 & .859 & 1.91 & 2.35 & & \\
\hline \multirow{3}{*}{$\begin{array}{l}\text { Your past teachers were very } \\
\text { supportive? (Q14) }\end{array}$} & Traditional & 24 & 3.00 & 1.103 & 2.53 & 3.47 & 2.87 & .10 \\
\hline & Non-traditional & 37 & 2.54 & .989 & 2.21 & 2.87 & & \\
\hline & Total & 61 & 2.72 & 1.051 & 2.45 & 2.99 & & \\
\hline \multirow{3}{*}{$\begin{array}{l}\text { You feel good attending your } \\
\text { current continuation school? } \\
(\mathrm{Q} 15)^{\star *}\end{array}$} & Traditional & 25 & 1.68 & .690 & 1.40 & 1.96 & 7.55 & .01 \\
\hline & Non-traditional & 37 & 2.30 & .968 & 1.97 & 2.62 & & \\
\hline & Total & 62 & 2.05 & .913 & 1.82 & 2.28 & & \\
\hline \multirow{3}{*}{$\begin{array}{l}\text { You believe your teachers want } \\
\text { you to succeed? (Q20) }\end{array}$} & Traditional & 25 & 2.08 & 1.115 & 1.62 & 2.54 & .04 & .85 \\
\hline & Non-traditional & 37 & 2.03 & .986 & 1.70 & 2.36 & & \\
\hline & Total & 62 & 2.05 & 1.031 & 1.79 & 2.31 & & \\
\hline
\end{tabular}

Note. ${ }^{* *}$ Statistically significant at $p<.05$. 
Table 24

Student Respondent Percentages of Question Variables Q9-Q22

\begin{tabular}{|c|c|c|c|c|}
\hline & $\begin{array}{l}\text { Traditional } \\
\text { School }_{n}\end{array}$ & Percentage & $\begin{array}{l}\text { Non- } \\
\text { Traditional } \\
\text { School }_{n} \\
\end{array}$ & Percentage \\
\hline $\begin{array}{l}\text { Your parents/caregiver are very } \\
\text { involved in your education? (Q9) }\end{array}$ & 25 & 76 & 37 & 84 \\
\hline $\begin{array}{l}\text { You would like your } \\
\text { parents/caregiver to be more } \\
\text { involved in your current education? } \\
\text { (Q10) }\end{array}$ & 25 & 56 & 37 & 71 \\
\hline $\begin{array}{l}\text { You believe your education in this } \\
\text { continuation school is important? } \\
\text { (Q11) }\end{array}$ & 25 & 96 & 37 & 90 \\
\hline $\begin{array}{l}\text { You believe that your current } \\
\text { teachers think your education is } \\
\text { important? (Q12) }\end{array}$ & 25 & 68 & 37 & 76 \\
\hline $\begin{array}{l}\text { Your current teachers are very } \\
\text { supportive? (Q13) }\end{array}$ & 25 & 72 & 37 & 65.4 \\
\hline $\begin{array}{l}\text { Your past teachers were very } \\
\text { supportive? (Q14) }\end{array}$ & 24 & 28 & 37 & 45.4 \\
\hline $\begin{array}{l}\text { You feel good attending your } \\
\text { current continuation school? (Q15) }\end{array}$ & 25 & 88 & 37 & 65.7 \\
\hline $\begin{array}{l}\text { You have many friends within this } \\
\text { school? (Q16) }\end{array}$ & 25 & 64 & 37 & 61 \\
\hline $\begin{array}{l}\text { You have many friends outside of } \\
\text { this school? (Q17) }\end{array}$ & 25 & 76 & 37 & 94 \\
\hline $\begin{array}{l}\text { You put in more time doing your } \\
\text { schoolwork at this continuation } \\
\text { school than you did at your previous } \\
\text { school? (Q18) }\end{array}$ & 25 & 72 & 37 & 65 \\
\hline $\begin{array}{l}\text { You believe you will be well } \\
\text { prepared for college or work after } \\
\text { you graduate from high school? } \\
\text { (Q19) }\end{array}$ & 25 & 68 & 37 & 89 \\
\hline $\begin{array}{l}\text { You believe your teachers want you } \\
\text { to succeed? (Q20) }\end{array}$ & 25 & 61 & 37 & 63 \\
\hline $\begin{array}{l}\text { You feel that you receive more } \\
\text { guidance at this school compared to } \\
\text { your previous school? (Q22) }\end{array}$ & 23 & 80 & 37 & 62.5 \\
\hline
\end{tabular}




\section{FIGURES}

Figure 1: Wiest, Wong, and Kreil (1998) Study Participants

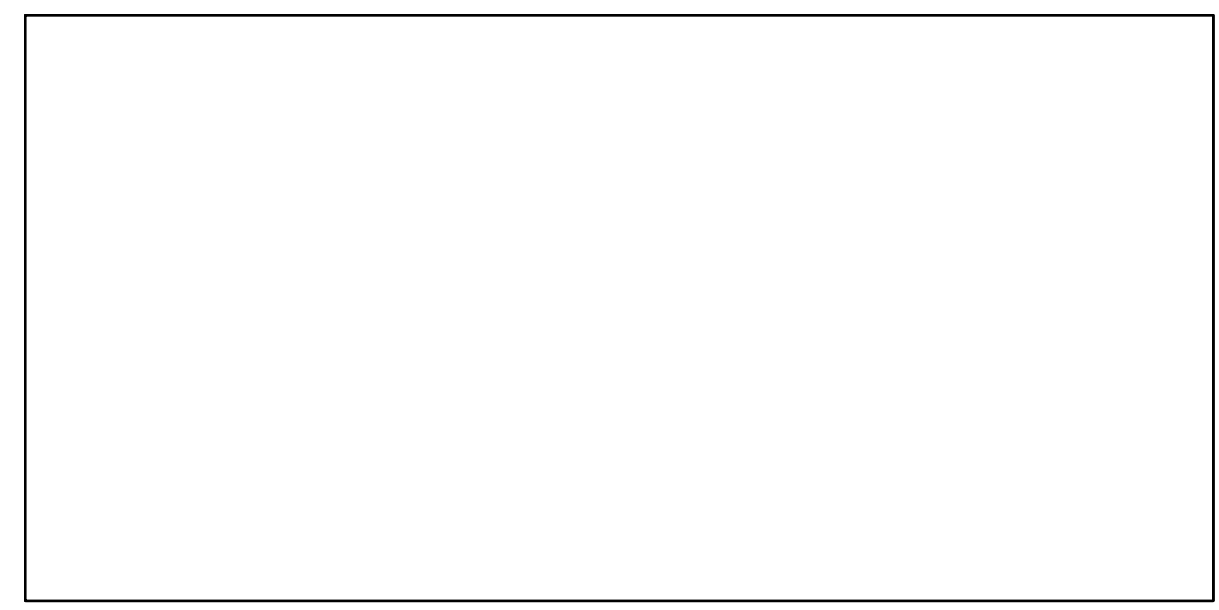


Figure 2: Student Responses to Q9 for School A

\begin{tabular}{c|cccc}
\hline Strongly Agree & Agree & $\begin{array}{c}\text { Somewhat } \\
\text { Agree/Disagree }\end{array}$ & Disagree & Strongly Disagree \\
\hline $40 \%$ & $36 \%$ & $16 \%$ & $0 \%$ & $8 \%$ \\
\hline
\end{tabular}

Parent/Caregiver involvement Scale in Percentage (School A)

$\square$ Strongly Agree $\square$ Agree $\square$ Somewhat Agree/Disagree $\square$ Strongly Disagree

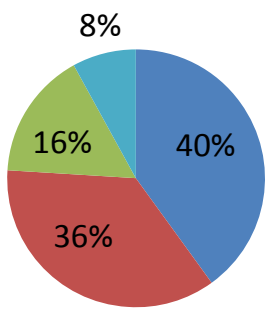

*Based on 25 responses 
Figure 3: Student Responses to Q9 for School B

\begin{tabular}{c|cccc}
\hline Strongly Agree & Agree & $\begin{array}{c}\text { Somewhat } \\
\text { Agree/Disagree }\end{array}$ & Disagree & Strongly Disagree \\
\hline $68 \%$ & $16 \%$ & $10 \%$ & $3 \%$ & $3 \%$ \\
\hline
\end{tabular}

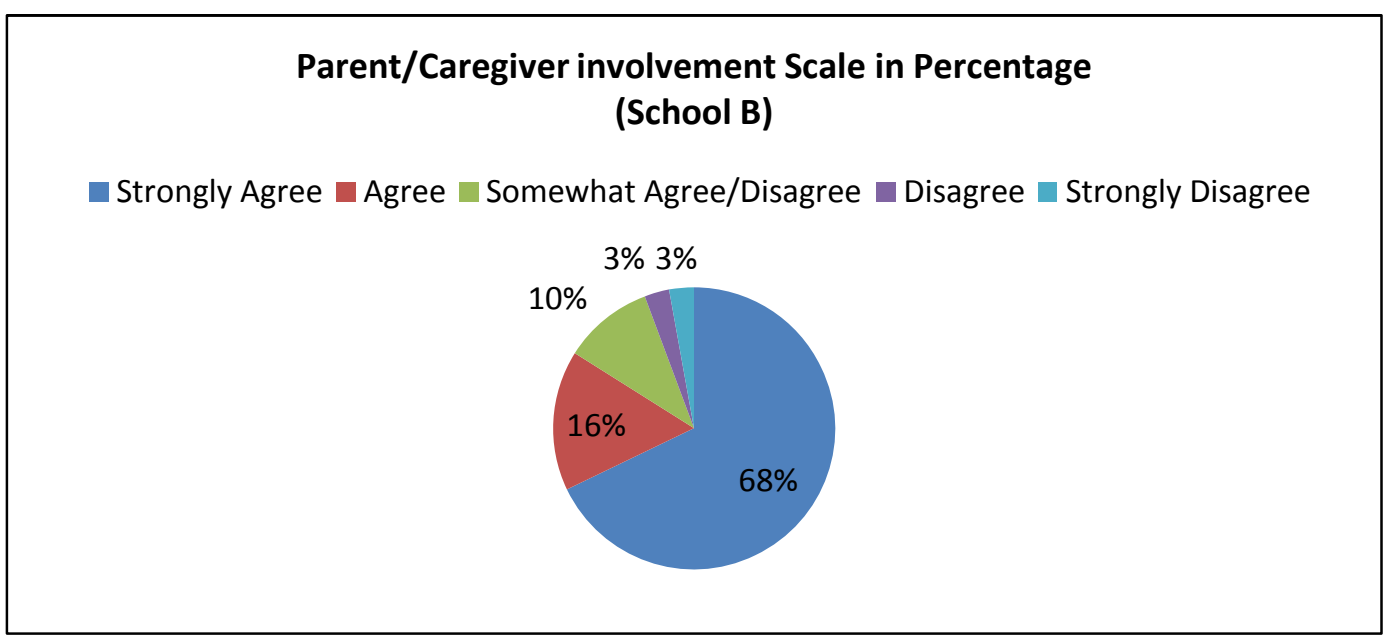

*Based on 37 responses 
Figure 4: Student Responses to Q10 for School A

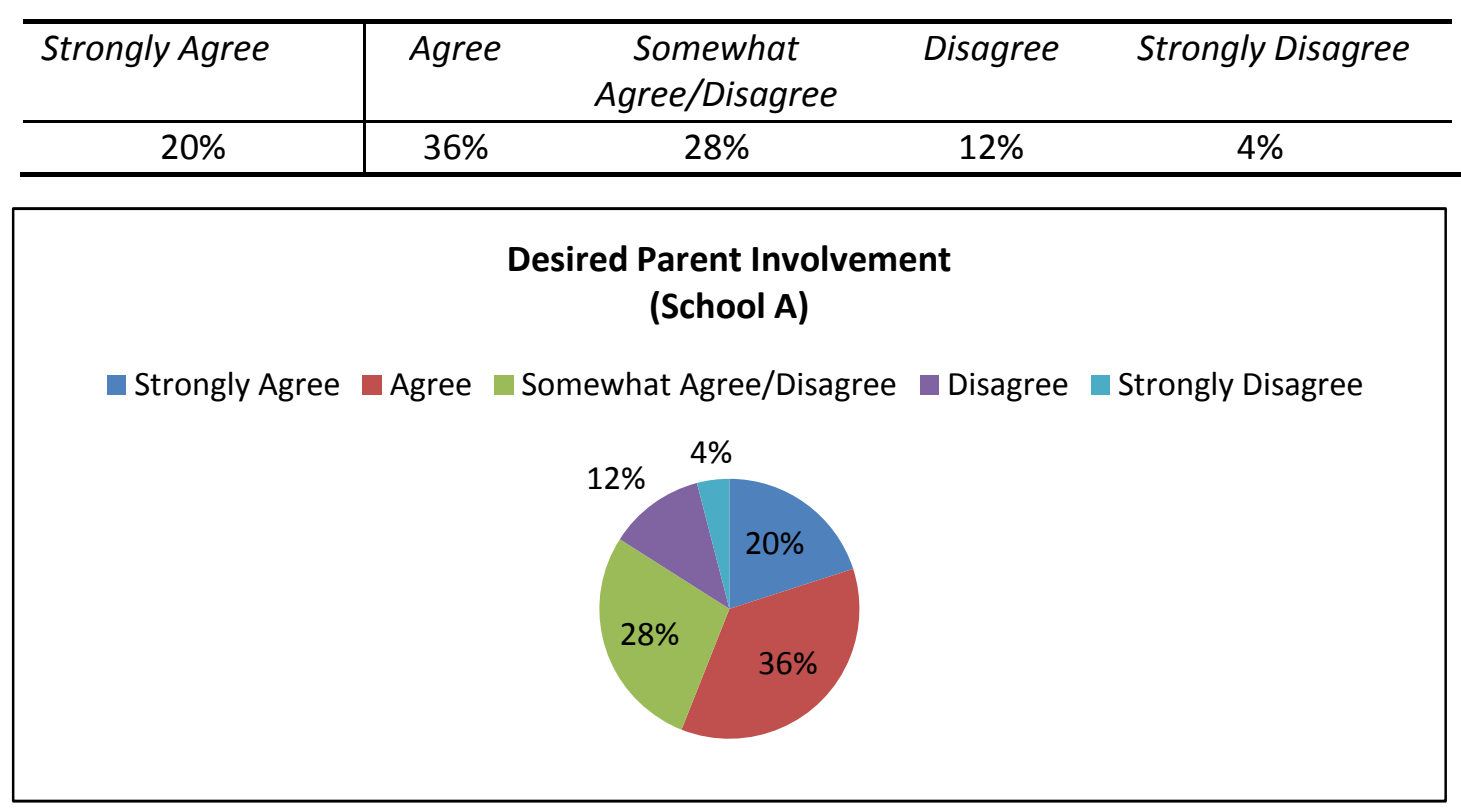

*Based on 25 responses 
Figure 5: Student Responses to Q10 for School B

\begin{tabular}{c|cccc}
\hline Strongly Agree & Agree & $\begin{array}{c}\text { Somewhat } \\
\text { Agree/Disagree }\end{array}$ & Disagree & Strongly Disagree \\
\hline $37 \%$ & $34 \%$ & $18 \%$ & $5 \%$ & $6 \%$ \\
\hline
\end{tabular}

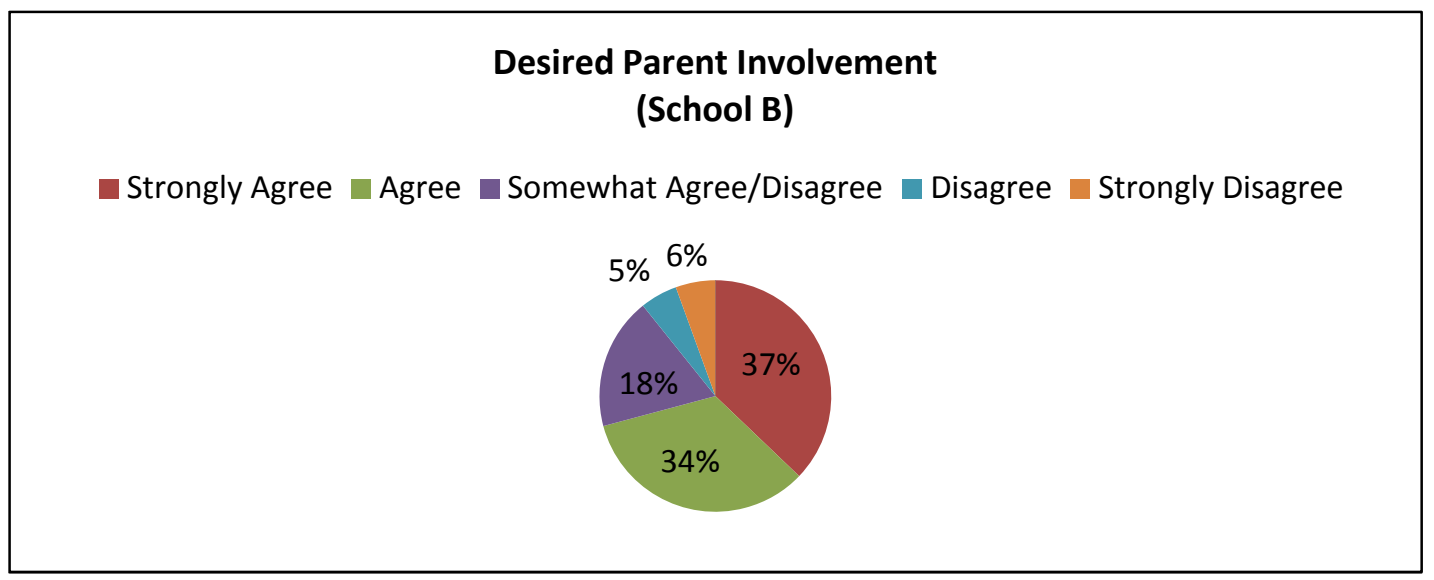

*Based on 37 responses 
Figure 6: Student Responses to Q11 for School A

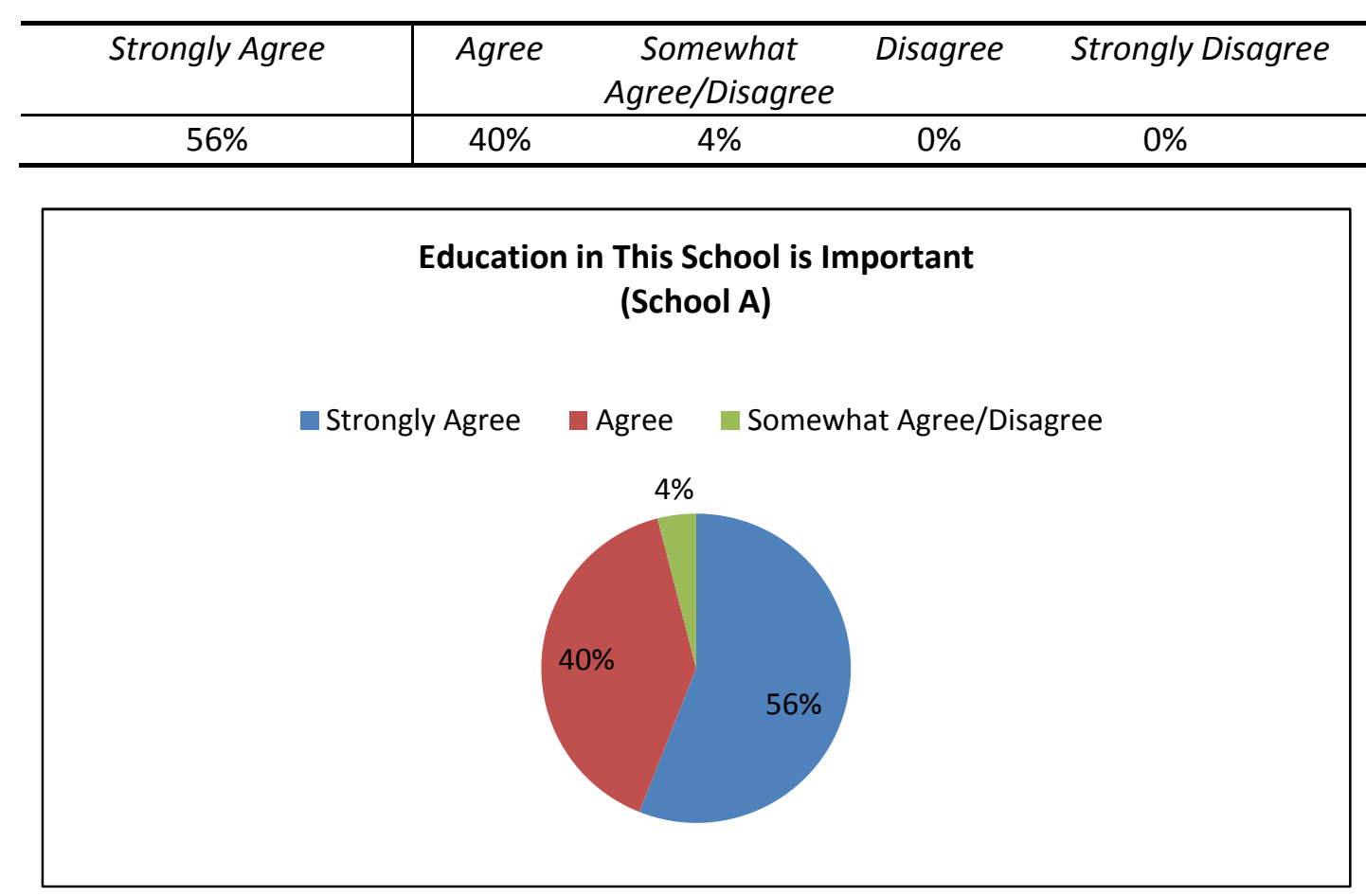

*Based on 25 responses 
Figure 7: Student Responses to Q11 for School B

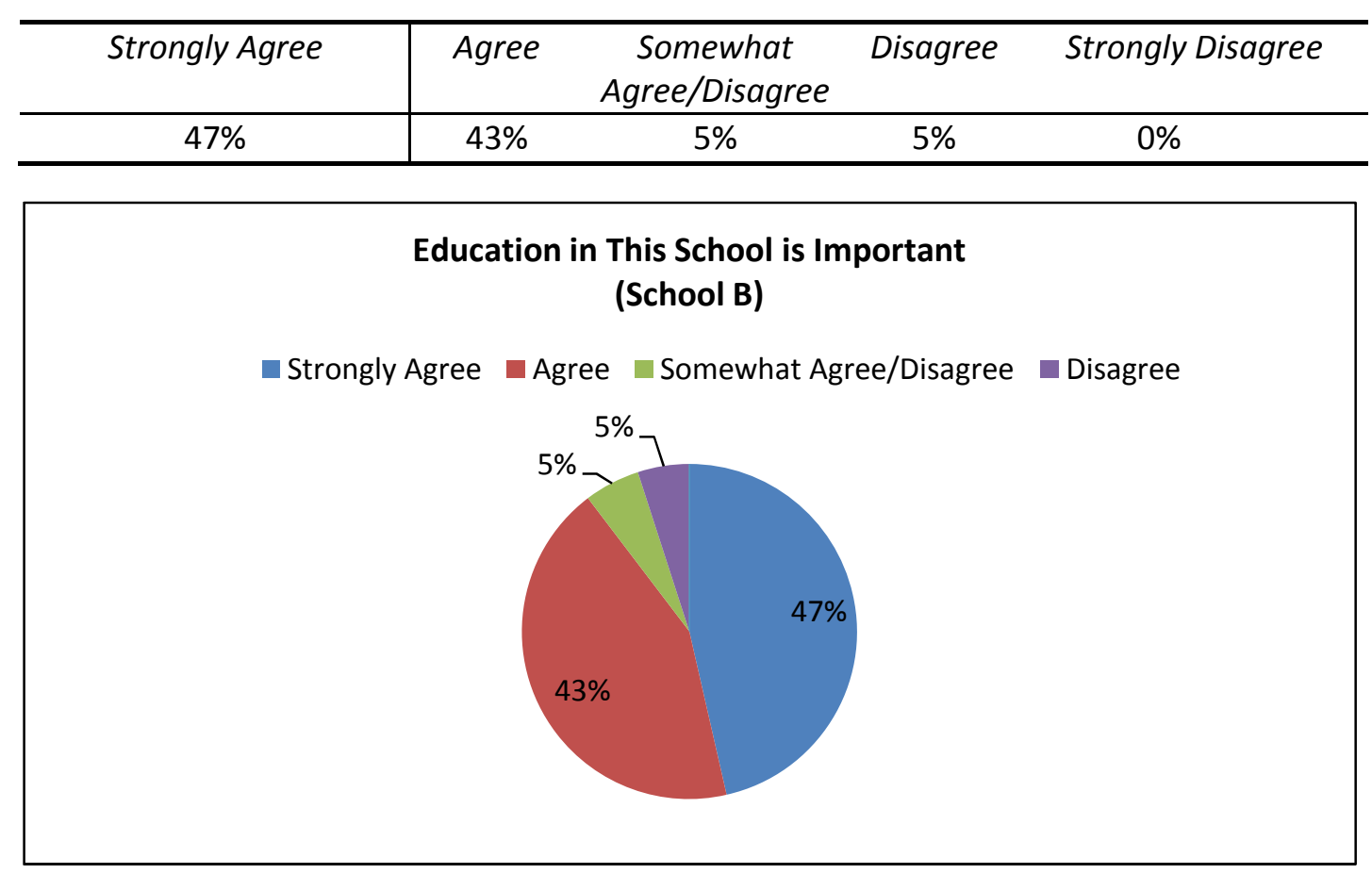

*Based on 37 responses 
Figure 8: Student Responses to Q16 for School A

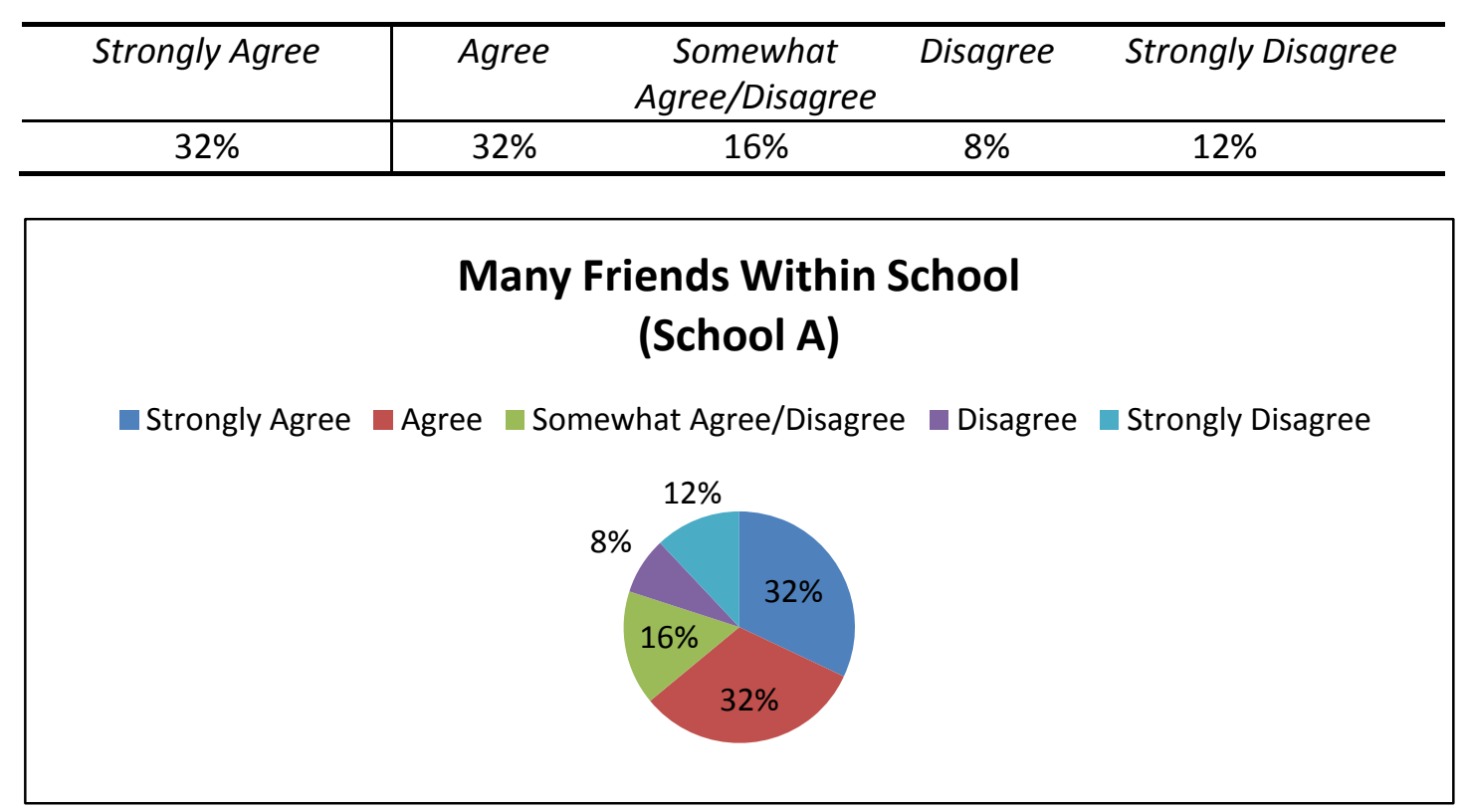

*Based on 25 responses 
Figure 9: Student Responses to Q16 for School B

\begin{tabular}{c|cccc}
\hline Strongly Agree & Agree & $\begin{array}{c}\text { Somewhat } \\
\text { Agree/Disagree }\end{array}$ & Disagree & Strongly Disagree \\
\hline $16 \%$ & $45 \%$ & $25 \%$ & $8 \%$ & $6 \%$ \\
\hline \multicolumn{4}{c}{$\begin{array}{c}\text { Many Friends Within School } \\
\text { (School B) }\end{array}$} \\
\hline Strongly Agree $\square$ Agree $\begin{array}{c}\text { Somewhat Agree/Disagree } \\
6 \%\end{array}$ \\
\end{tabular}

*Based on 37 responses 
Figure 10: Student Responses to Q17 for School A

\begin{tabular}{c|cccc}
\hline Strongly Agree & Agree & $\begin{array}{c}\text { Somewhat } \\
\text { Agree/Disagree }\end{array}$ & Disagree & Strongly Disagree \\
\hline $60 \%$ & $16 \%$ & $16 \%$ & $8 \%$ & $0 \%$ \\
\hline
\end{tabular}

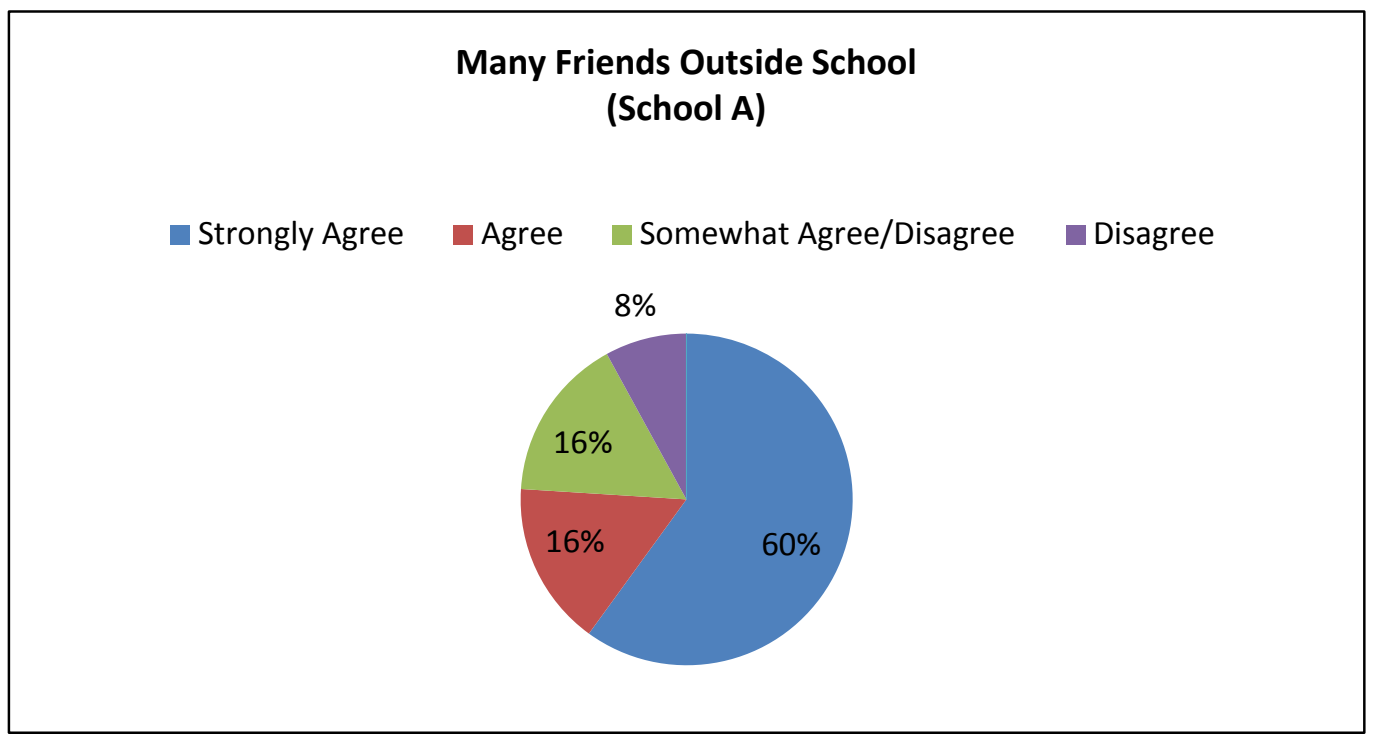

*Based on 25 responses 
Figure 11: Student Responses to Q17 for School B

\begin{tabular}{c|cccc}
\hline Strongly Agree & Agree & $\begin{array}{c}\text { Somewhat } \\
\text { Agree/Disagree }\end{array}$ & Disagree & Strongly Disagree \\
\hline $65 \%$ & $29 \%$ & $6 \%$ & $0 \%$ & $0 \%$ \\
\hline
\end{tabular}

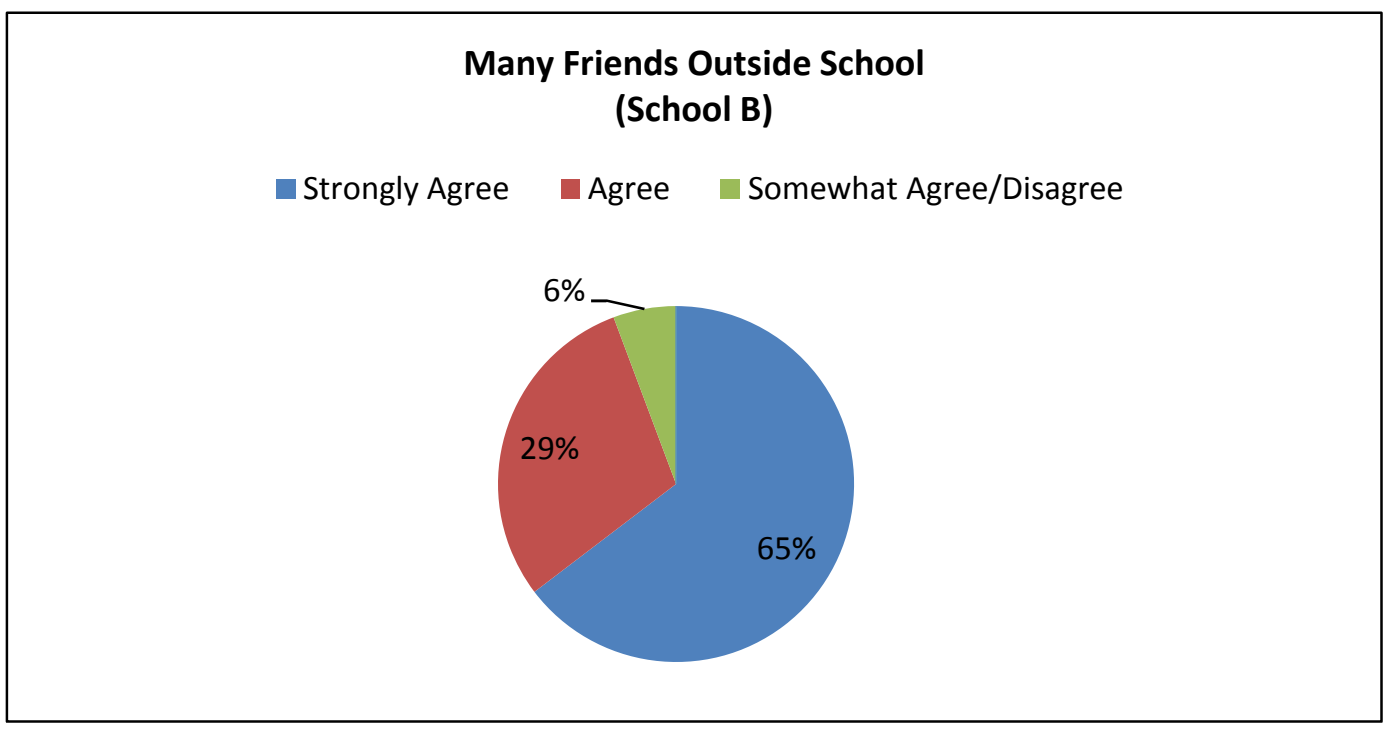

*Based on 37 responses 
Figure 12: Student Responses to Q18 for School A

\begin{tabular}{c|cccc}
\hline Strongly Agree & Agree & $\begin{array}{c}\text { Somewhat } \\
\text { Agree/Disagree }\end{array}$ & Disagree & Strongly Disagree \\
\hline $52 \%$ & $20 \%$ & $24 \%$ & $4 \%$ & $0 \%$ \\
\hline
\end{tabular}

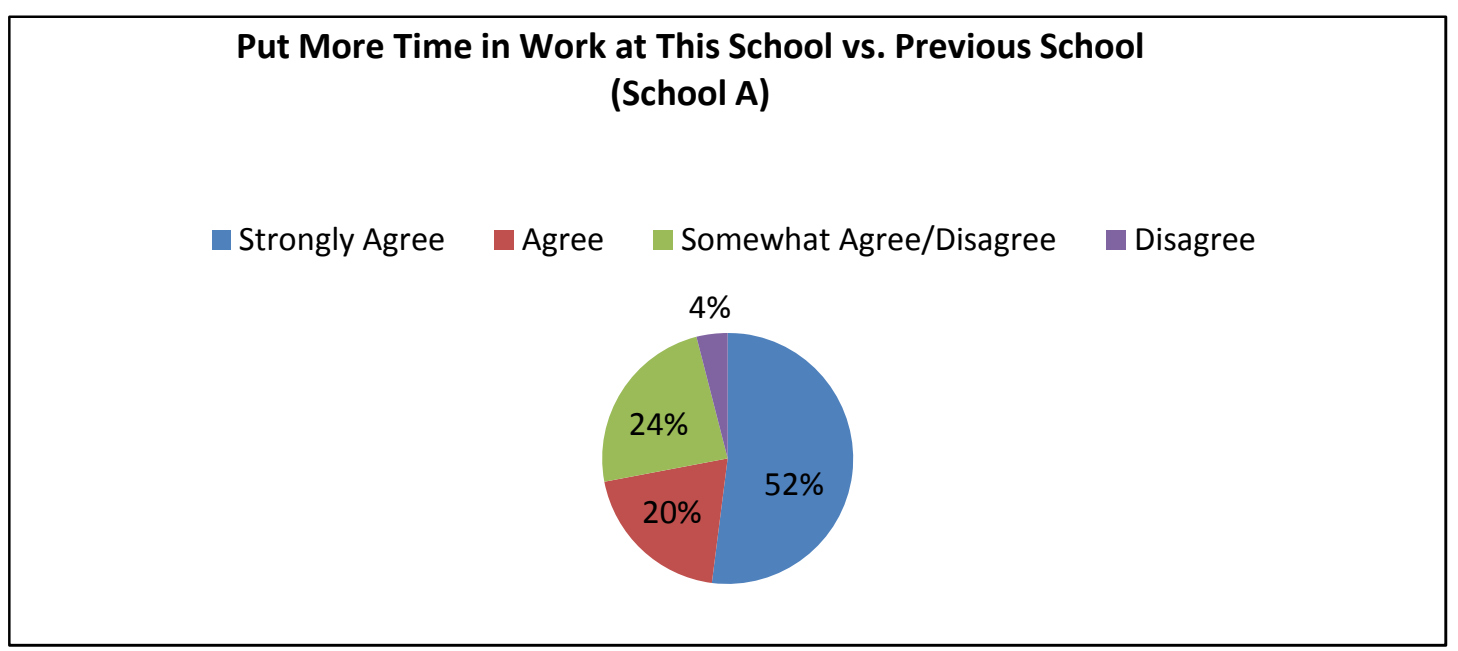

*Based on 25 responses 
Figure 13: Student Responses to Q18 for School B

\begin{tabular}{c|cccc}
\hline Strongly Agree & Agree & $\begin{array}{c}\text { Somewhat } \\
\text { Agree/Disagree }\end{array}$ & Disagree & Strongly Disagree \\
\hline $44 \%$ & $21 \%$ & $19 \%$ & $8 \%$ & $8 \%$ \\
\hline
\end{tabular}

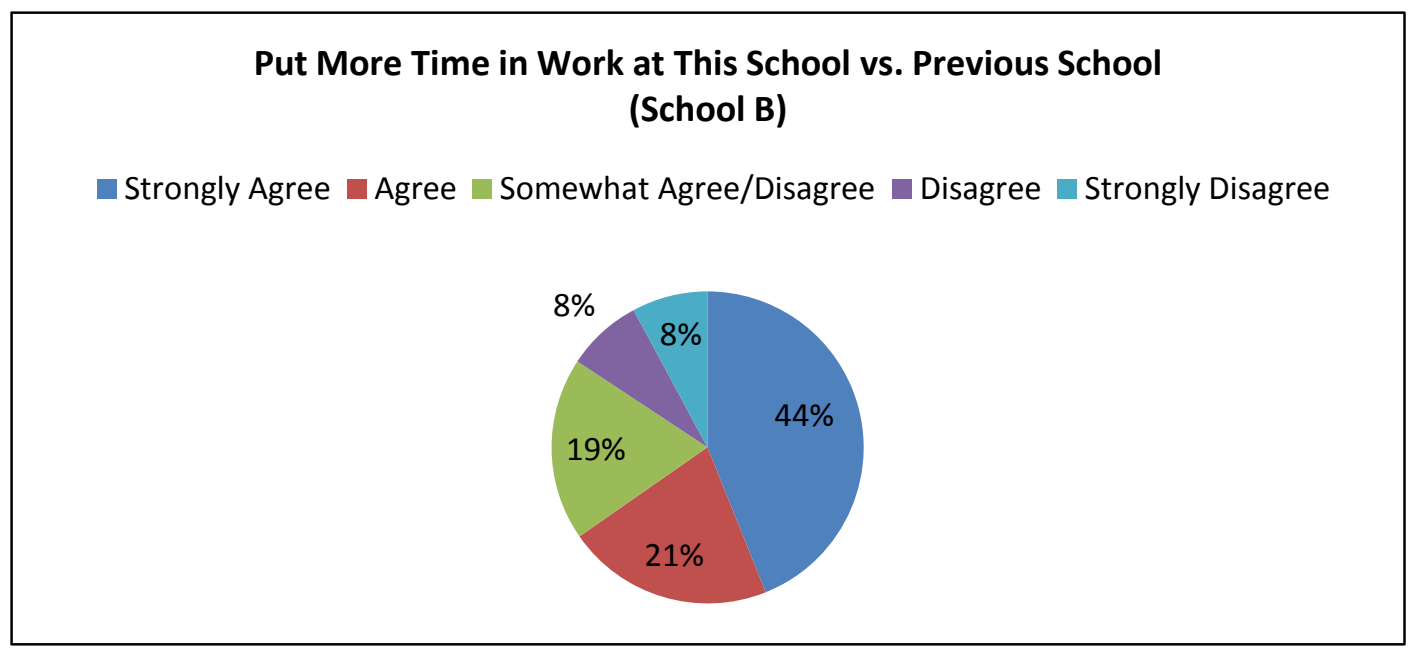

*Based on 37 responses 
Figure 14: Student Responses to Q19 for School A

\begin{tabular}{c|cccc}
\hline Strongly Agree & Agree & $\begin{array}{c}\text { Somewhat } \\
\text { Agree/Disagree }\end{array}$ & Disagree & Strongly Disagree \\
\hline $28 \%$ & $40 \%$ & $24 \%$ & $8 \%$ & $0 \%$ \\
\hline
\end{tabular}

Believe You Will Be Prepared For College or Work Post Grad (School A)

Strongly Agree $\square$ Agree $\square$ Somewhat Agree/Disagree $\square$ Disagree

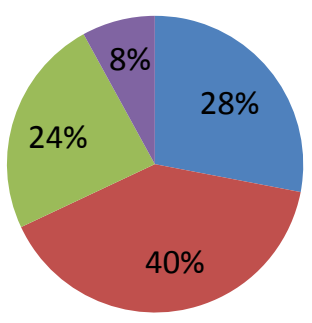

*Based on 25 responses 
Figure 15: Student Responses to Q19 for School B

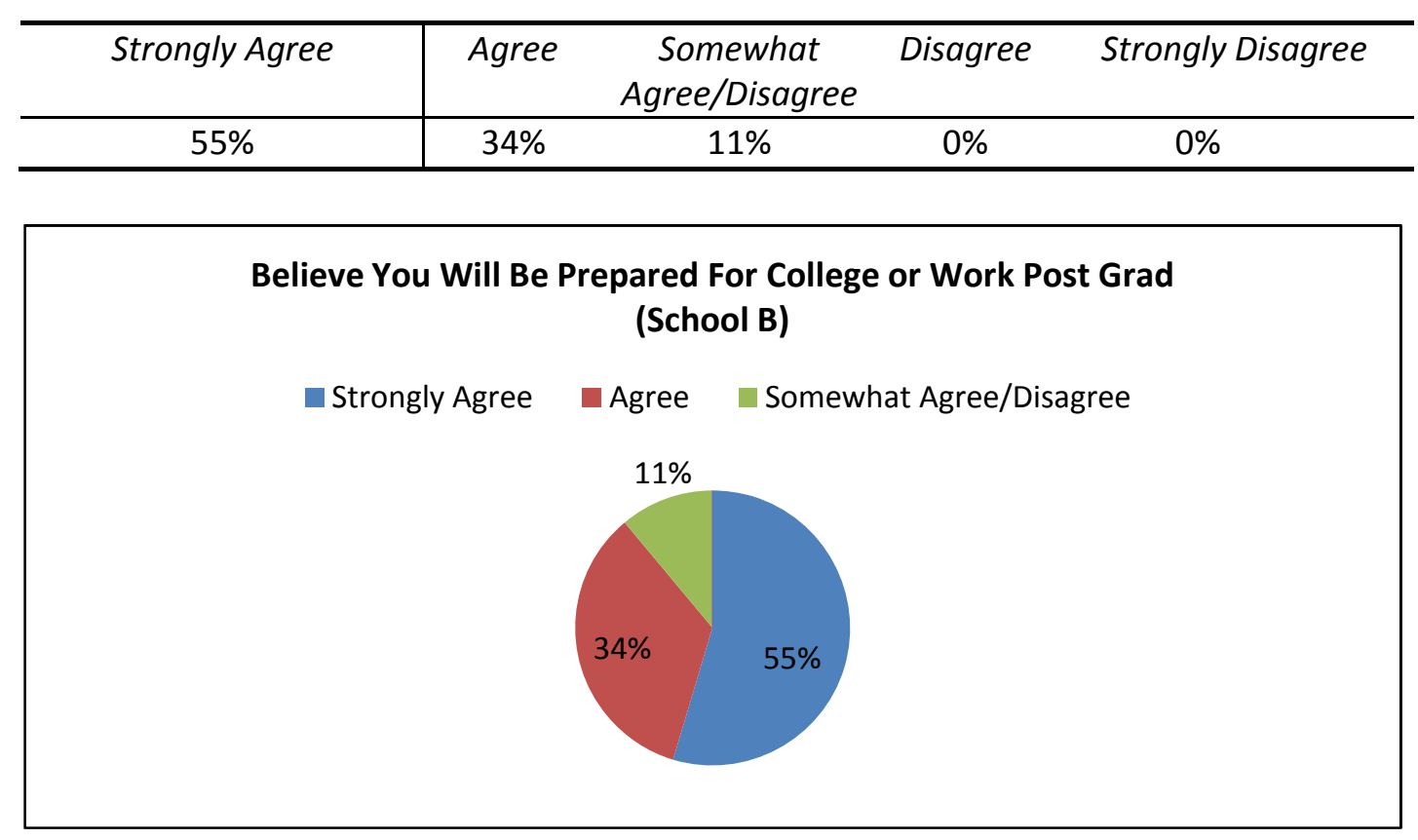

*Based on 37 responses 
Figure 16: Student Responses to Q22 for School A

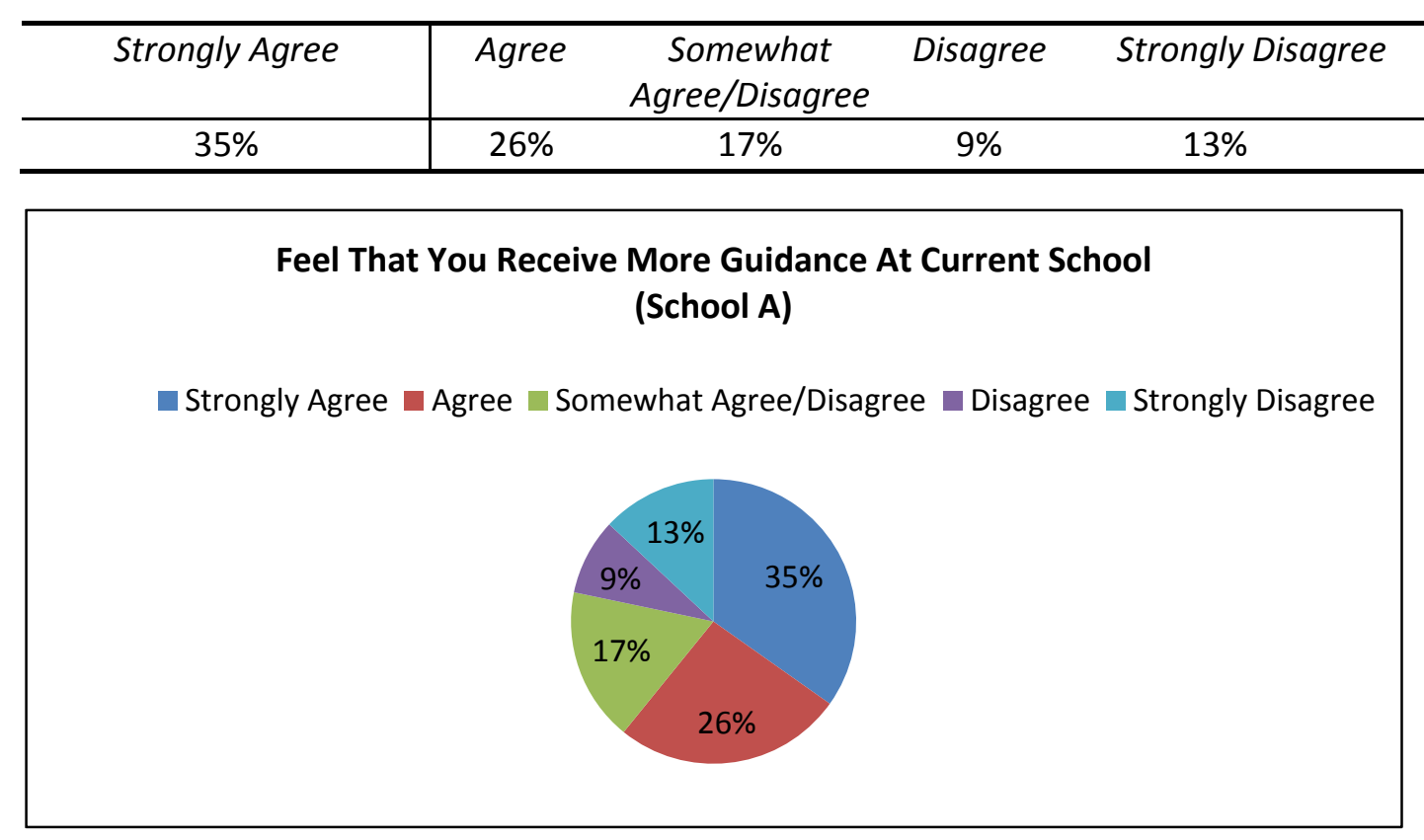

*Based on 23 responses 
Students' Experience in Continuation Schools

154

Figure 17: Student Responses to Q22 for School B

\begin{tabular}{c|cccc}
\hline Strongly Agree & Agree & $\begin{array}{c}\text { Somewhat } \\
\text { Agree/Disagree }\end{array}$ & Disagree & Strongly Disagree \\
\hline $25 \%$ & $38 \%$ & $27 \%$ & $7 \%$ & $3 \%$ \\
\hline
\end{tabular}

Feel Better About Receiving More Guidance At Current School (School B)

Strongly Agree $\square$ Agree $\square$ Somewhat Agree/Disagree $\square$ Disagree $\square$ Strongly Disagree

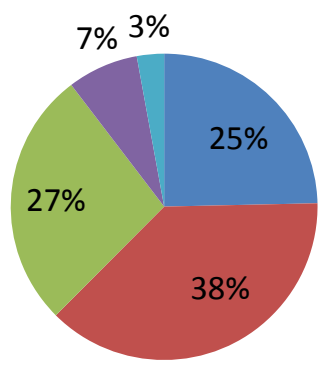

*Based on 37 responses 
Figure 18: Student Responses to Q12 for School A

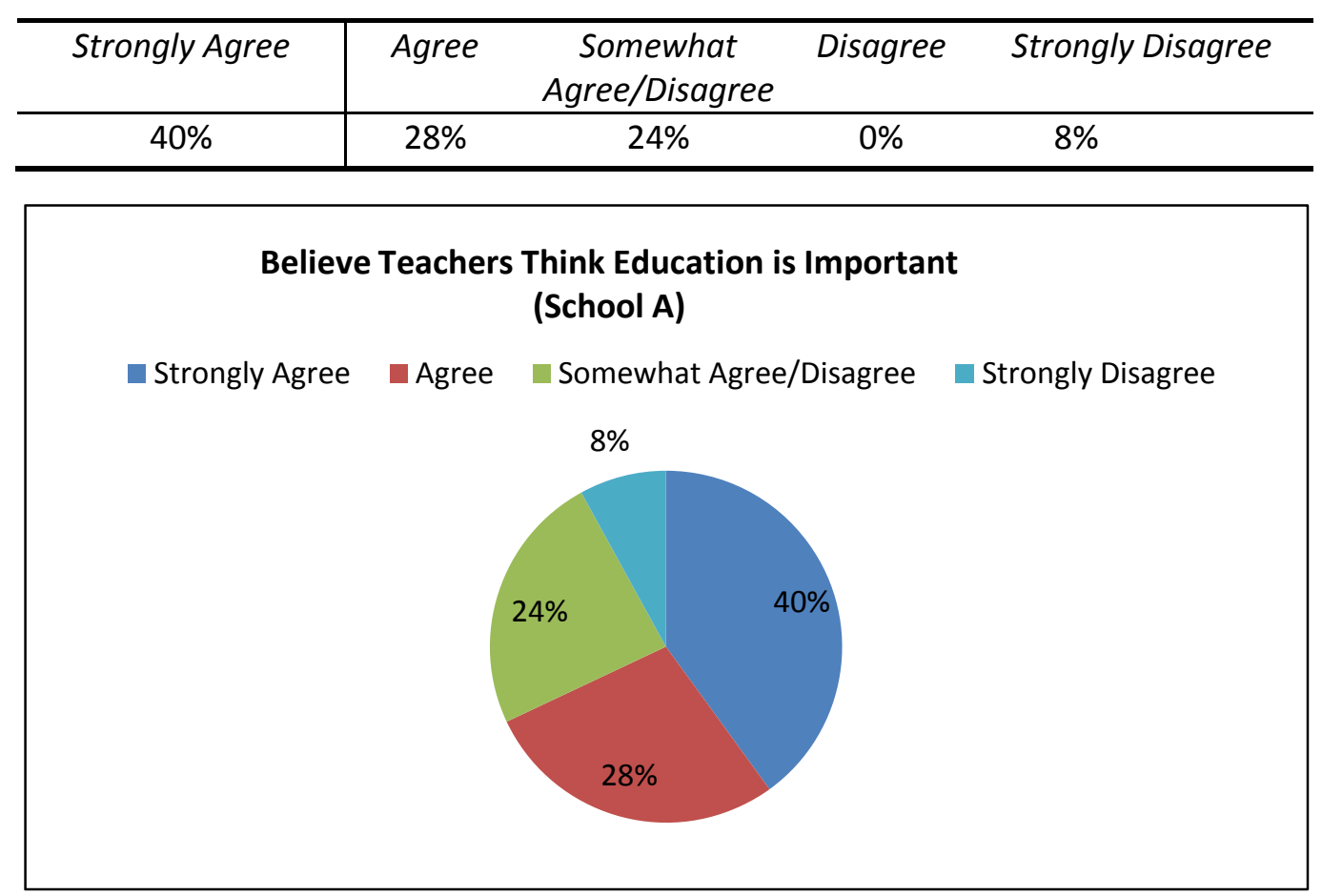

*Based on 25 responses 
Figure 19: Student Responses to Q12 for School B

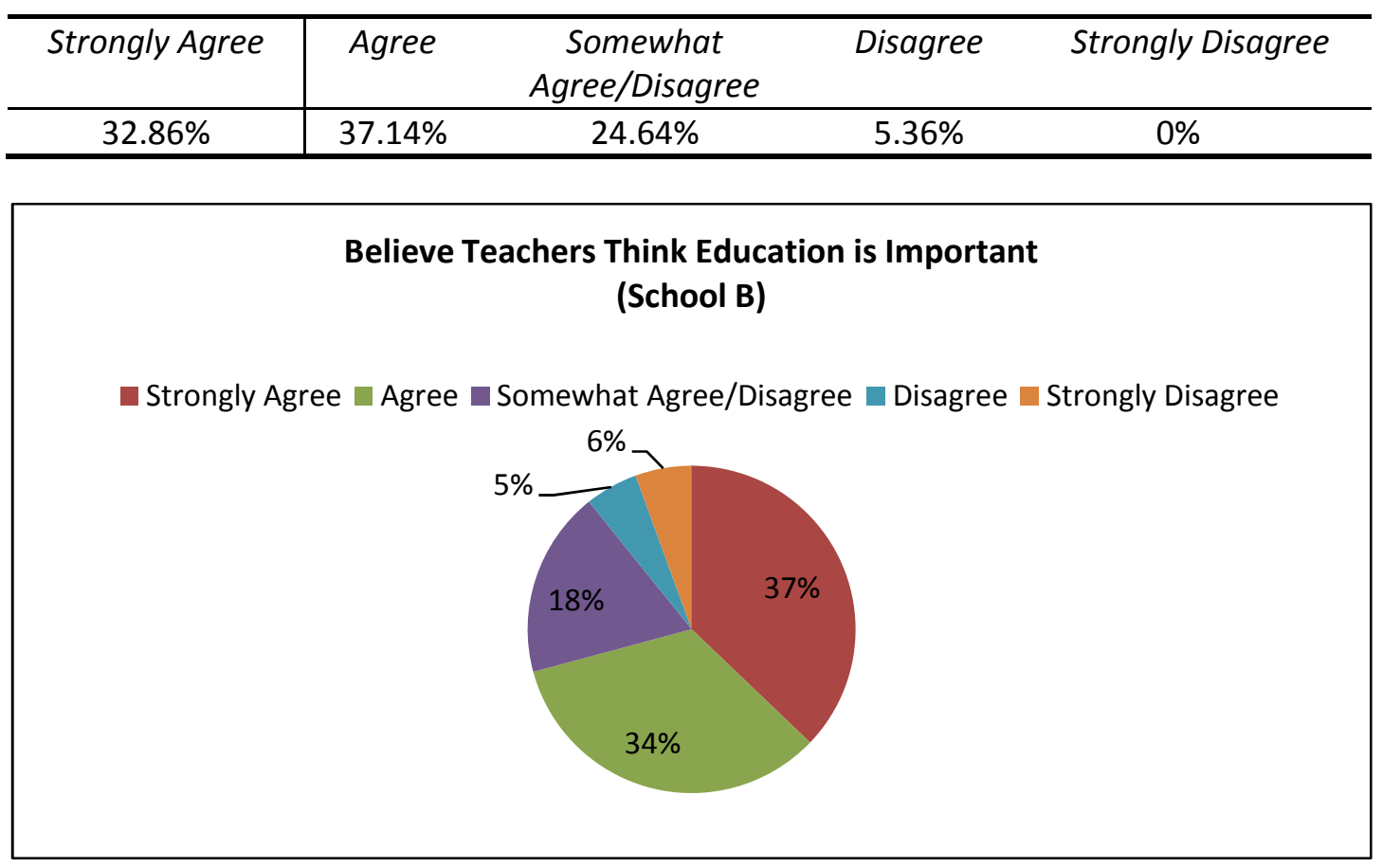

*Based on 37 responses 
Figure 20: Student Responses to Q13 for School A

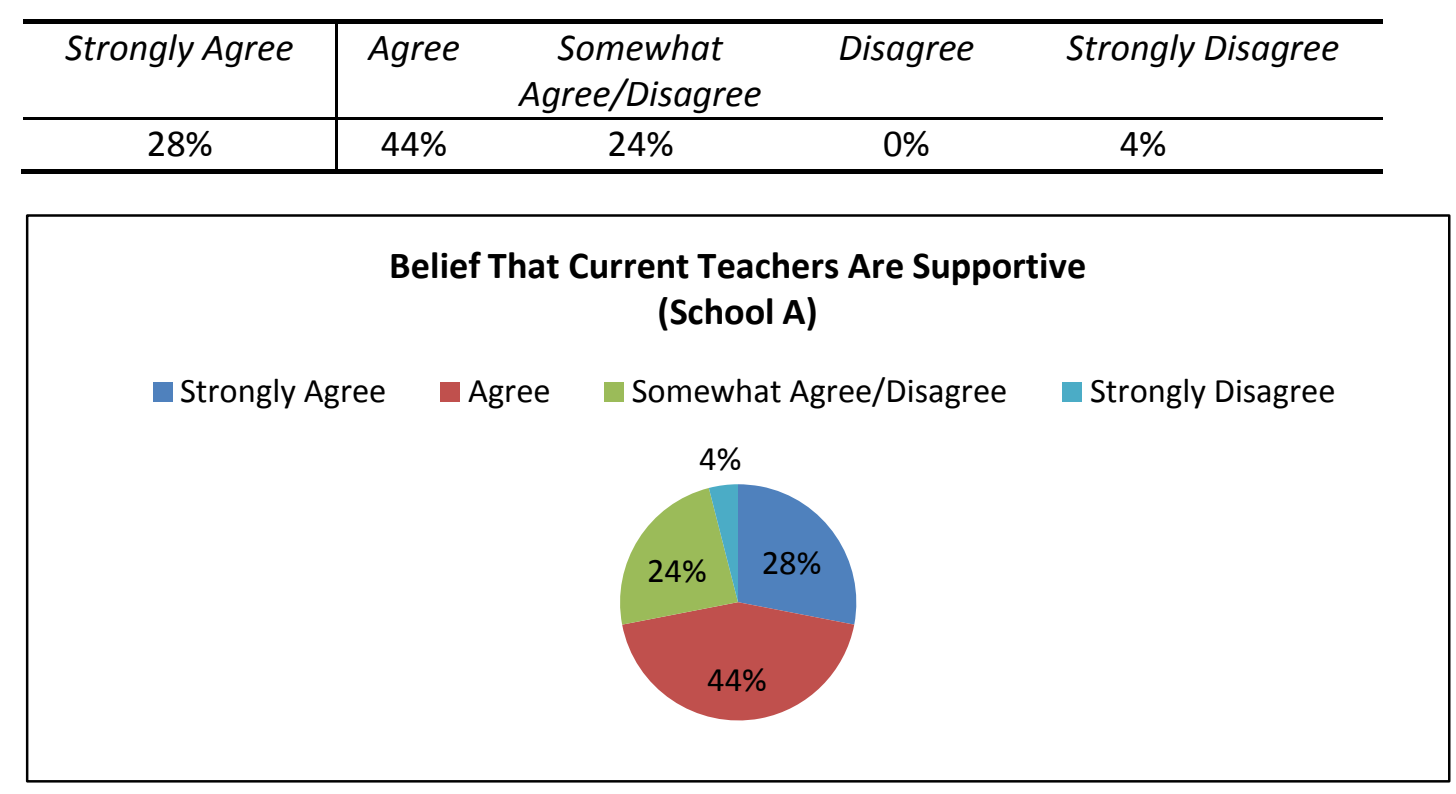

*Based on 25 responses 
Figure 21: Student Responses to Q13 for School B

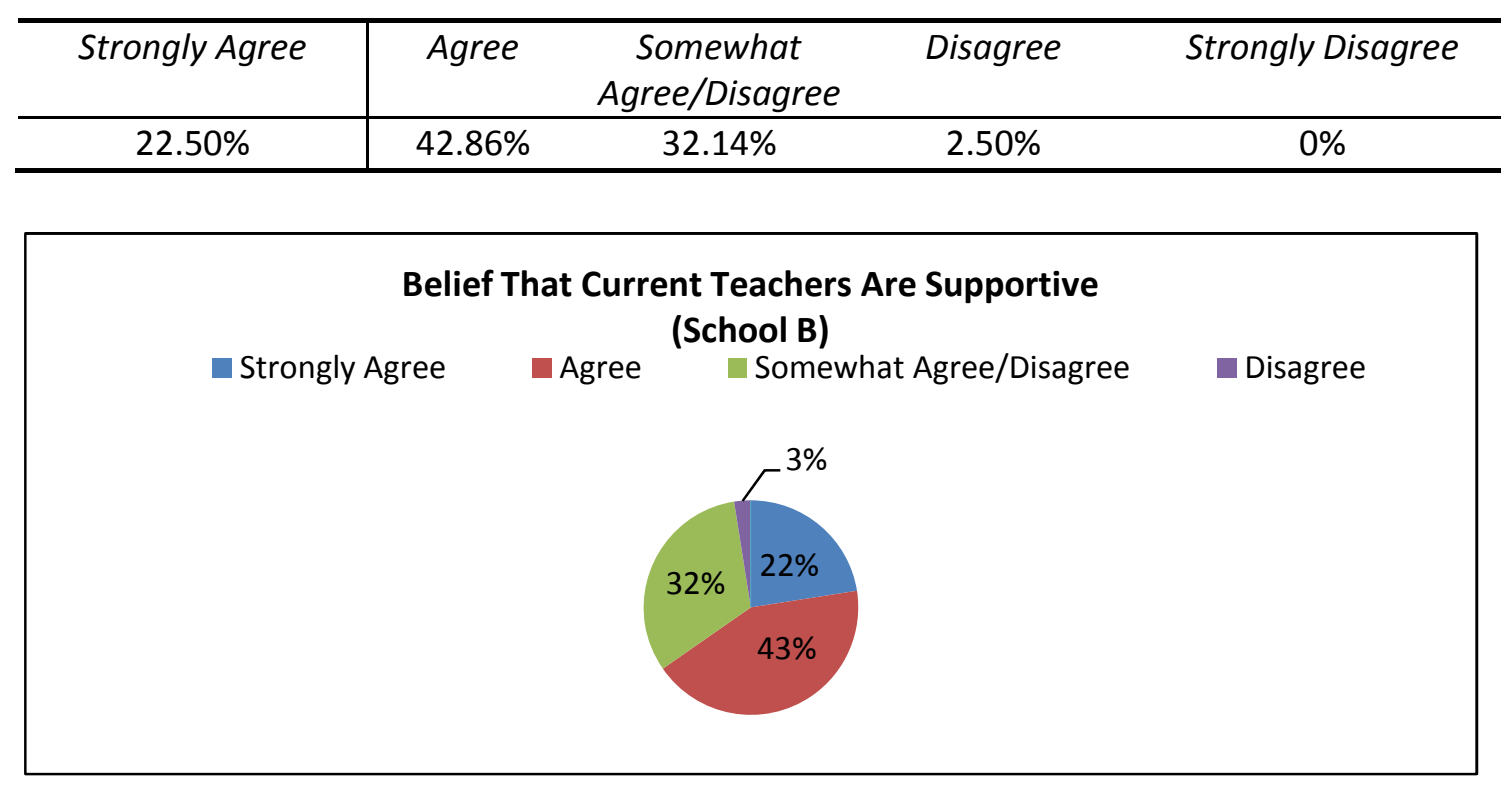

*Based on 37 responses 
Figure 22: Student Responses to Q14 for School A

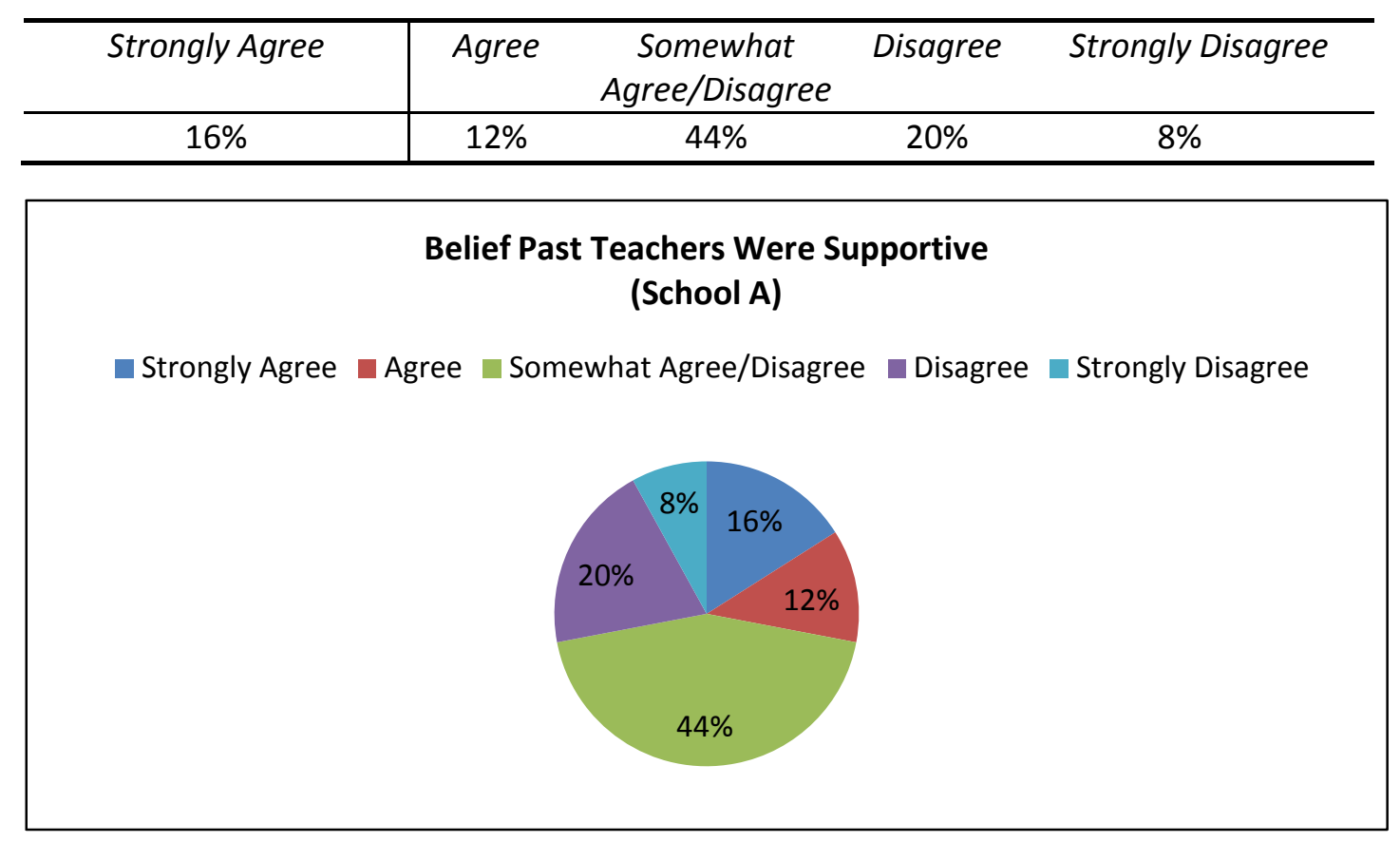

*Based on 24 responses 
Figure 23: Student Responses to Q14 for School B

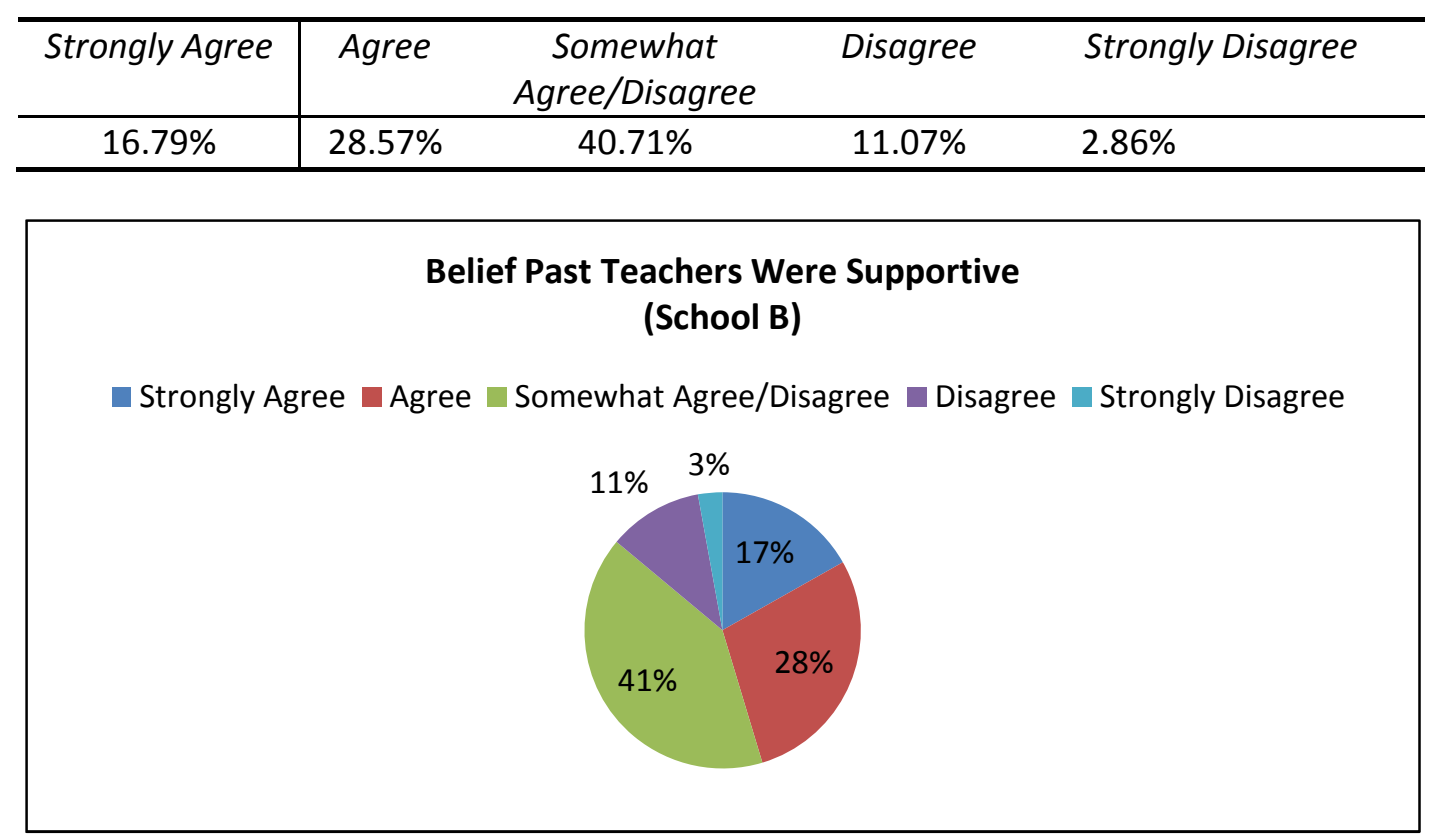

*Based on 37 responses 
Figure 24: Student Responses to Q15 for School A

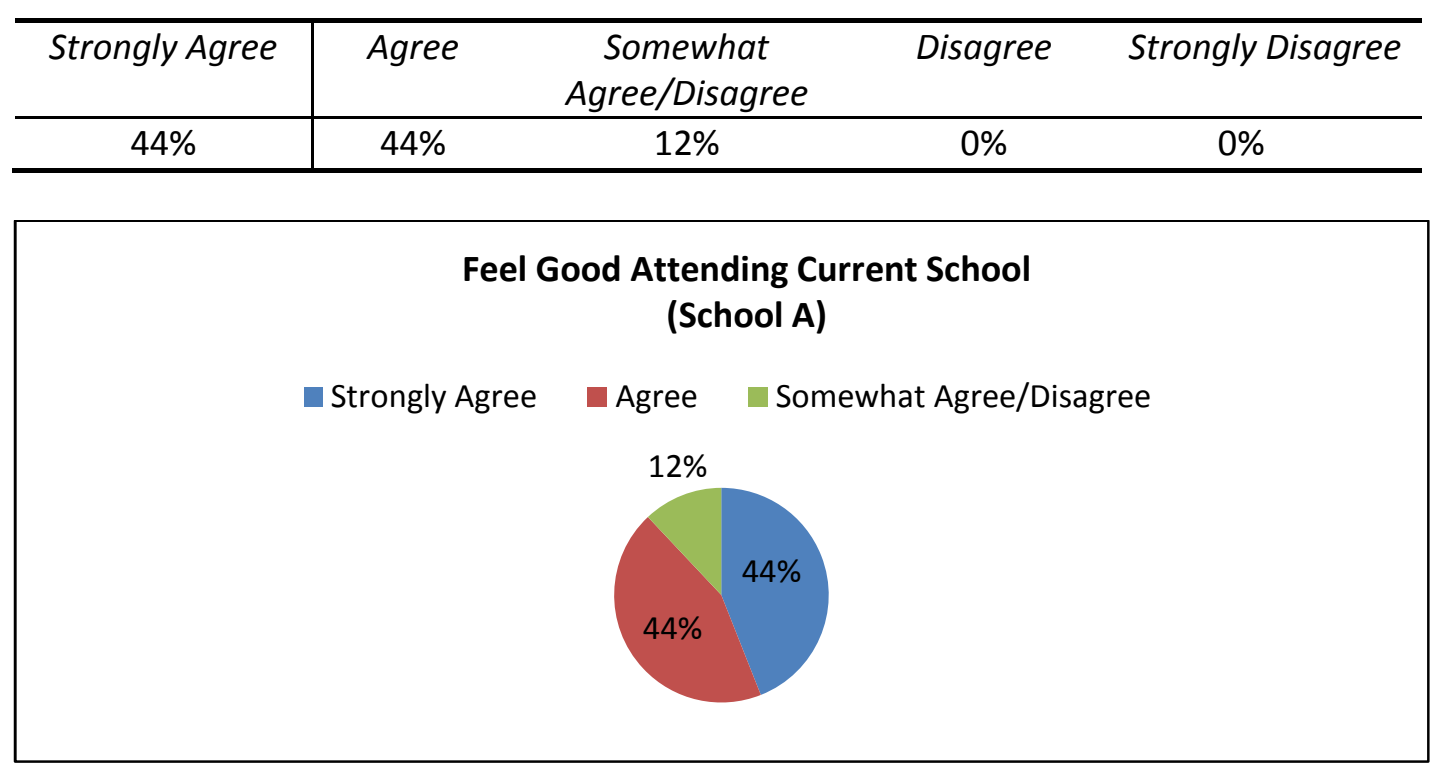

*Based on 25 responses 
Figure 25: Student Responses to Q15 for School B

\begin{tabular}{c|cccc}
\hline Strongly Agree & Agree & $\begin{array}{c}\text { Somewhat } \\
\text { Agree/Disagree }\end{array}$ & Disagree & Strongly Disagree \\
\hline $19.64 \%$ & $46.07 \%$ & $23.57 \%$ & $7.86 \%$ & $2.86 \%$ \\
\hline
\end{tabular}

\section{Feel Good Attending Current School}

(School B)

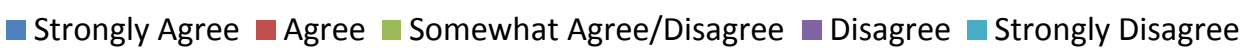

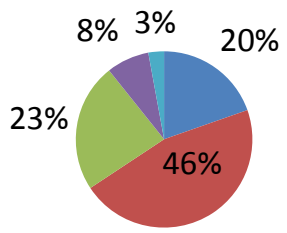

*Based on 37 responses 
Figure 26: Student Responses to Q20 for School A

\begin{tabular}{c|cccc}
\hline Strongly Agree & Agree & $\begin{array}{c}\text { Somewhat } \\
\text { Agree/Disagree }\end{array}$ & Disagree & Strongly Disagree \\
\hline $32 \%$ & $48 \%$ & $4 \%$ & $12 \%$ & $4 \%$ \\
\hline
\end{tabular}

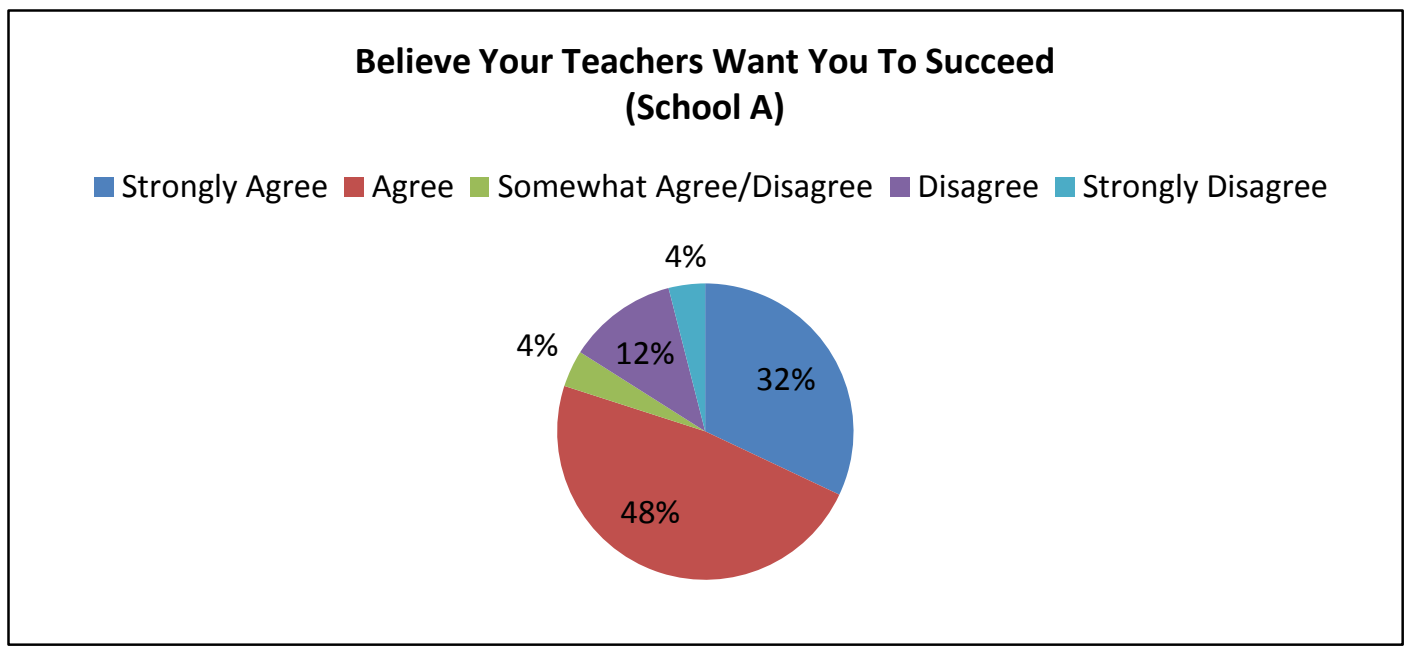

*Based on 25 responses 
Figure 27: Student Responses to Q20 for school B

\begin{tabular}{c|cccc}
\hline Strongly Agree & Agree & $\begin{array}{c}\text { Somewhat } \\
\text { Agree/Disagree }\end{array}$ & Disagree & Strongly Disagree \\
\hline $41.07 \%$ & $21.43 \%$ & $32.14 \%$ & $5.36 \%$ & $0 \%$ \\
\hline
\end{tabular}

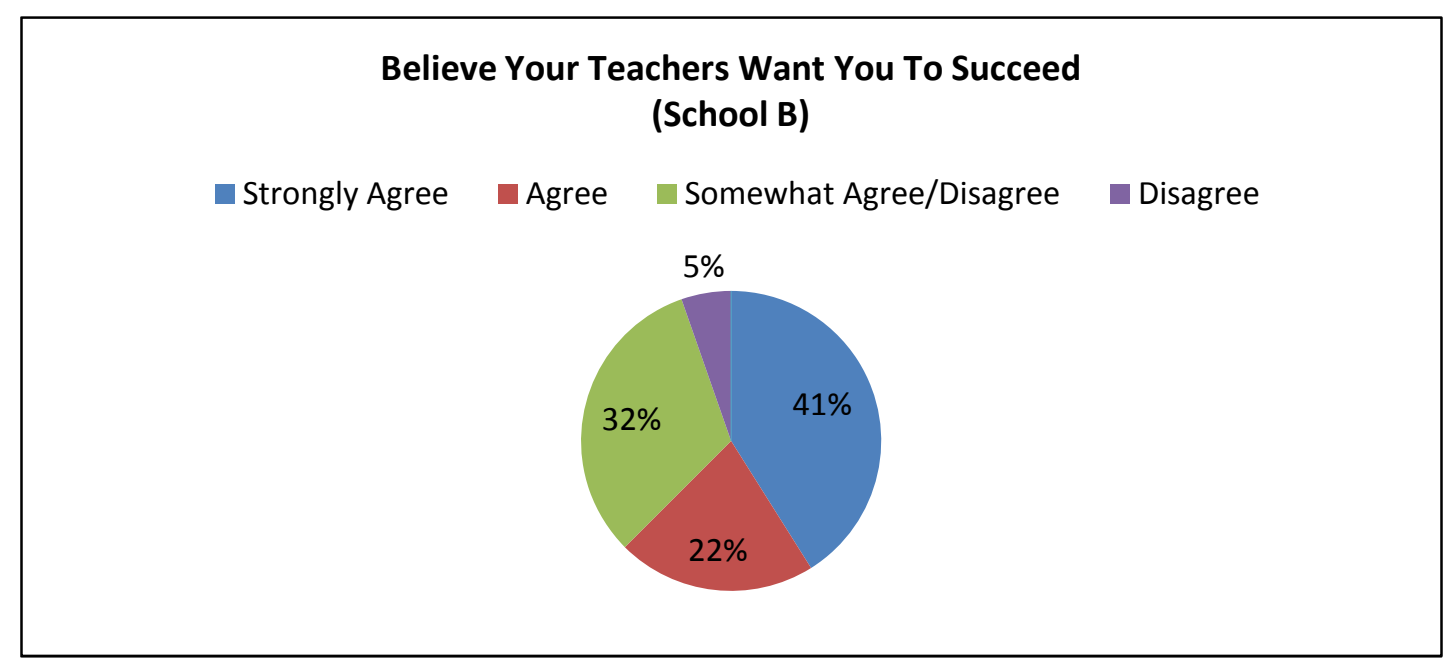

*Based on 37 responses 


\section{APPENDIX A}

\section{STUDENT SURVEY}

\section{Continuation School Experiences}

\section{Student Survey}

\section{Demographics \& Education Experience}

1. What is your gender?

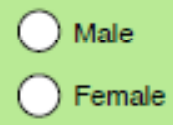

2. What is your age?

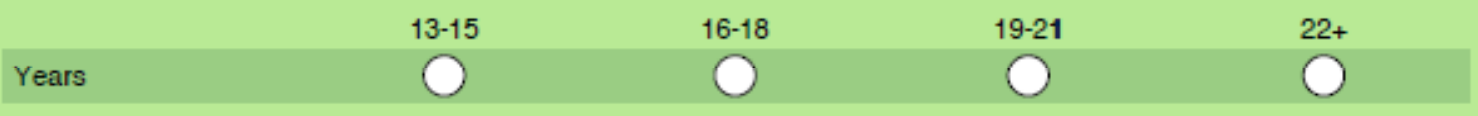

3. What grade are you in?

Grade Level $\quad \bigcirc^{\text {th }} \bigcirc^{11 \text { th }}$

4. In what grade did you begin attending this school?

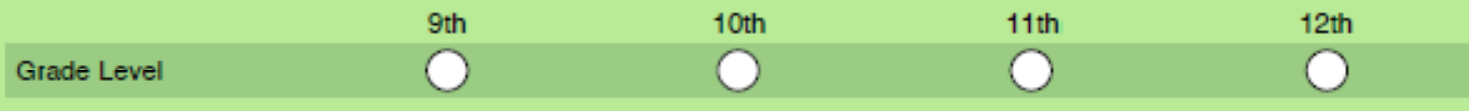

5. How long have you attended this school?

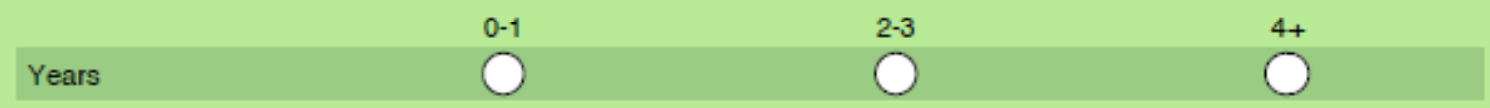

6. Prior to coming to this school, what type of school did you attend?

School $\quad \begin{array}{ccc}\text { Traditional Public } \\ \text { School }\end{array}$

7. Your reason for attending this school relates to one of the following?
Discipline Issues
Credit Recovery

8. Your home environment is most like one of the following choices:

Home Type

9. Your parents/caregiver are very involved in your education?

Scale $\quad$ Agree $\begin{gathered}\text { Somewhat } \\ \text { Agree/Disagree }\end{gathered}$




\section{Continuation School Experiences}

10. You would IIke your parents/careglver to be more Involved In your current education?

\begin{tabular}{|c|c|c|c|c|c|}
\hline & Strongly Agree & Agree & $\begin{array}{c}\text { Somewhat } \\
\text { Agree/Dieagree }\end{array}$ & Uisagree & Strongly Uisagree \\
\hline Scale & & & & & \\
\hline
\end{tabular}

11. You believe your education in this continuation school is important?

Sc:ale $\quad$ Agree $\quad \begin{gathered}\text { Eomcwhat } \\ \text { Agree/Ulsagree }\end{gathered}$

12. You believe that your current teachers think your education is important?

\begin{tabular}{|c|c|c|c|c|c|}
\hline & Strongly $\wedge$ gree & Agree & $\begin{array}{c}\text { Somewhat } \\
\text { Agree/Disagree }\end{array}$ & Dieagree & Strongly Dieagree \\
\hline 3cale & & & & & \\
\hline
\end{tabular}

13. Your currenl leachiers are very supporlive?

\begin{tabular}{|c|c|c|c|c|c|}
\hline & Strongly Agree & Agree & $\begin{array}{c}\text { Somewhat } \\
\text { Agree/Disagree }\end{array}$ & Disagree & Strongly Disagree \\
\hline Scale & & & & & \\
\hline
\end{tabular}

14. Your past teachers were very supportive?

\begin{tabular}{|c|c|c|c|c|c|}
\hline & Strongly Agree & Agree & $\begin{array}{c}\text { Somewhat } \\
\text { Aylee/Disayıree }\end{array}$ & Disagree & Strongly Disagree \\
\hline Scale & & & & & \\
\hline
\end{tabular}

15. You feel gond attending your current continuation school?

Sccle $\quad$ Strongly Agree $\quad$ Agree $\quad \begin{gathered}\text { Sumluwhlat } \\ \text { Agree/Disagree }\end{gathered}$

16. You have many fricnds within this school?

\begin{tabular}{|c|c|c|c|c|c|}
\hline & Btrongly Agree & Agree & $\begin{array}{c}\text { Somewhat } \\
\text { Agree//hisagree }\end{array}$ & Disagree & Btrongly Disagree \\
\hline Scale & & & & & \\
\hline
\end{tabular}

1\%. You have many triends outside of this school?

$\begin{array}{ccccc}\text { Strongly Agree } & \text { Agree } & \begin{array}{c}\text { Somewhat } \\ \text { Agree/Disagree }\end{array} & \text { Disagree } & \text { Strongly Disagree }\end{array}$

18. You put in more time doing your school work at this continuation school than you did at your previous echool?

3cale Etrongly Agrce Agrce $\quad 0 \quad$ Agree/Disagree $\quad 0$




\section{ContInuation School Experlences}

19. You believe you will be well prepared for college or work after you graduate from High School?

Scale Strongly Agree Agree Aomcwhat

20. You believe your teachere want you to eucceed?

Scale Strongly Agree Agree Bomewhat

21. You have diecueeed with eomeone (other than a peer) optione for you after high echool?
(Yes
(No

22. You feel that you receive more guidance at this school compared to your previous school?

Scale Strongly Agree Agree Somewhat $\begin{gathered}\text { SoreelUisagree } \\ \text { Aisagree }\end{gathered}$

23. In your uwn words, please explain huw you feel su far abuul allending this sthuol?

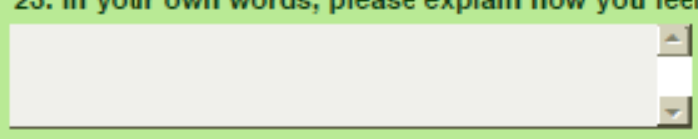

24. What steps are you taking to prepare for college/work after high school?

24. What steps are you taking to prepare for college/v 


\title{
APPENDIX B \\ INFORMED CONSENT LETTER-STUDENT
}

\author{
INFORMED CONSENT LETTER (Student)
}

For

\section{AFRICAN AMERICAN STUDENTS' PERCEPTIONS OF THEIR CONTINUATION SCHOOL EXPERIENCE}

\section{Purpose and Procedures}

You are invited to participate in a research study that will research the experience of African American students attending continuation schools. The purpose of the study is to ascertain your perceptions related to your school placement, family system structure, and your future experiences after high school. Upon volunteering for the study you will be asked to fill out a survey. These will be conducted at your school site and should only take approximately 10-15 minutes. Only the students at this school will be completing the survey. The questions asked will be about the students' demographics and perceptions about their education experiences. Neither teachers nor administrators will be asked any questions about students.

\section{Risks}

The risks for you to participate in this study are minimal. However, if uncomfortable feelings occur you can schedule a time to meet with this researcher about those feelings.

\section{Benefits}

While participation in this study may be of no direct personal benefit to you, what we learn from you will be helpful for students who currently are receiving, or are being considered for alternative education services in continuation schools. You may find it helpful to share your personal experience, whether they are positive or negative.

\section{Participants Rights}

Your participation in this study is completely voluntary and you are free to choose what information you want to reveal. You may decline to answer a question at any time. Stopping the survey will in no way affect you in any way.

\section{Confidentiality}

Students will not be required to divulge any personal information in the survey. Responses are completely anonymous. Your names will not be on the survey. The survey will be assigned a number for data collection purposes. All identifying material will be purged when quotes or case examples are used in the presentation or publication of study results. Audio/video taping will not be used in this study. 


\section{Cost and Reimbursement}

There is no cost to you for participating in the study, nor will you be paid.

\section{Impartial Third Party Contact}

If you wish to contact an impartial third party not associated with this study regarding any question or complaint you may have about the study, you may contact Dr. Catherine Salmon at (909) 748-8672 for information or assistance.

\section{Informed Consent Statement}

I have read the contents of the consent form and have listened to the verbal explanation given by the investigator. My questions have been answered to my satisfaction. I hereby give voluntary consent to participate in this study. Signing this consent document does not waive my rights nor does it release the investigators, institution or sponsors from their responsibilities. I may call or email Dr. Ron Morgan at (909) $\underline{748-8801 /}$ ron_morgan@redlands.edu or Shyrea Roberson at (909) 748-8803/ shyrea_roberson@redlands.edu if I have additional questions or concerns. I have been given a copy of this consent form.

Signature of Participant

Date

Signature of Investigator 


\section{APPENDIX C \\ INFORMED CONSENT LETTER-PARENT}

INFORMED CONSENT LETTER

\section{For \\ AFRICAN AMERICAN STUDENTS' PERCEPTIONS OF THEIR \\ CONTINUATION SCHOOL EXPERIENCE}

\section{Purpose and Procedures}

You are invited to participate in a research study that will research the experience of African American students attending continuation schools. The purpose of the study is to ascertain your perceptions related to your school placement, family system structure, and your future experiences after high school. Upon volunteering for the study you will be asked to fill out a survey. These will be conducted at your school site and should only take approximately 10-15 minutes. Only the students at this school will be completing the survey. The questions asked will be about the students' demographics and perceptions about their education experiences. Neither teachers nor administrators will be asked any questions about students.

\section{Risks}

The risks for you to participate in this study are minimal. However, if uncomfortable feelings occur you can schedule a time to meet with this researcher about those feelings.

\section{Benefits}

While participation in this study may be of no direct personal benefit to you, what we learn from you will be helpful for students who currently are receiving, or are being considered for alternative education services in continuation schools. You may find it helpful to share your personal experience, whether they are positive or negative.

\section{Participants Rights}

Your participation in this study is completely voluntary and you are free to choose what information you want to reveal. You may decline to answer a question at any time. Stopping the survey will in no way affect you in any way.

\section{Confidentiality}

Students will not be required to divulge any personal information in the survey.

Responses are completely anonymous. Your names will not be on the survey. The survey will be assigned a number for data collection purposes. All identifying material will be purged when quotes or case examples are used in the presentation or publication of study results. Audio/video taping will not be used in this study.

\section{Cost and Reimbursement}

There is no cost to you for participating in the study, nor will you be paid. 


\section{Impartial Third Party Contact}

If you wish to contact an impartial third party not associated with this study regarding any question or complaint you may have about the study, you may contact Dr. Catherine Salmon at (909) 748-8672 for information or assistance.

\section{Informed Consent Statement}

I have read the contents of the consent form and have listened to the verbal explanation given by the investigator. My questions have been answered to my satisfaction. I hereby give voluntary consent to participate in this study. Signing this consent document does not waive my rights nor does it release the investigators, institution or sponsors from their responsibilities. I may call or email Dr. Ron Morgan at (909) $\underline{748-8801 /}$ ron_morgan@redlands.edu or Shyrea Roberson at (909) 748-8803/ shyrea_roberson@redlands.edu if I have additional questions or concerns. I have been given a copy of this consent form.

Signature of Parent (if participants is under 18 years of age) Date 


\title{
APPENDIX D
}

\section{DISTRICT APPROVAL LETTER - SCHOOL A}

\author{
II. STATEMENT OF AGREEMENT
}

In conducting research in the and conditions as follows:

A. Research Activities will remain in compliance with the following Federal Regulations:

a. The Family Educational Rights and Privacy Act (FERPA: 34 CFR Part 99) which is designed to protect the privacy of a student's education records at all public elementary and secondary schools and virtually all public and private postsecondary institutions available at

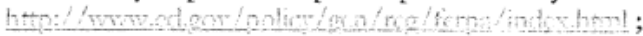

b. The Protection of Pupil Rights Amendment (PPRA: 34 CFR Part 98) which is designed to protect the rights of parents and students in programs that receive funding from the Department of

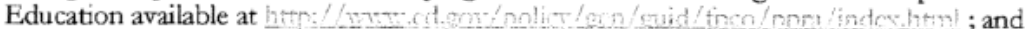

c. The Ethical Principals of Psychologists and Code of Conduct from the American Psychological

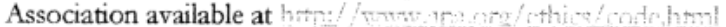

B. All data collected from the must be used for graduate level work at the aforementioned institution, sponsoring entity or agency which seeks to add to research in the field of education and to inform student academic achievement.

C. Qualitative studies which involve anecdotal data from students require written permission from parents/legal guardians.

D. Any modifications or amendments to the original proposal must be submitted in writing to the Instructional Services Division Office of Research, Testing, and Accountability.

E. The researcher(s) agrees to submit an abstract and executive summary of the findings to the Instructional Services Division Office of Research, Testing, and Accountability.

By signing below, you are indicating that you agree to abide by the terms of this agreement.
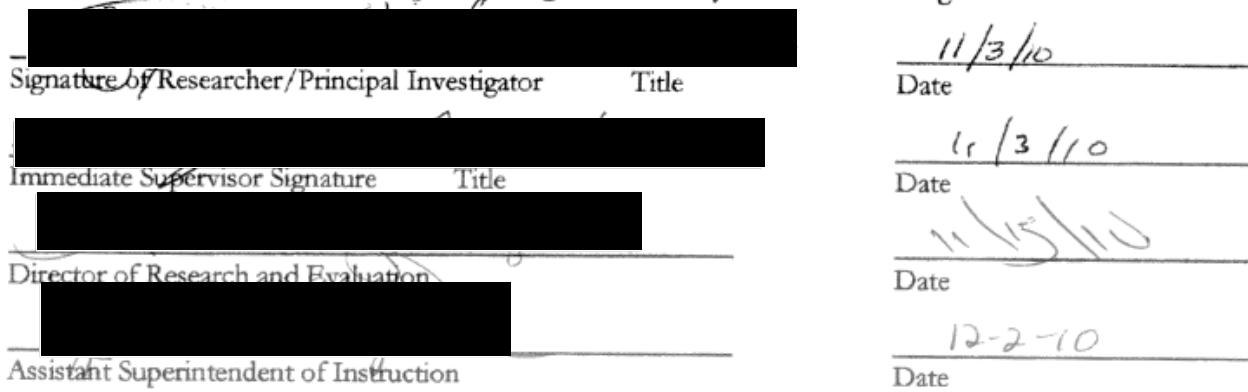

Date 


\section{APPENDIX E}

\section{DISTRICT APPROVAL LETTER - SCHOOL B}

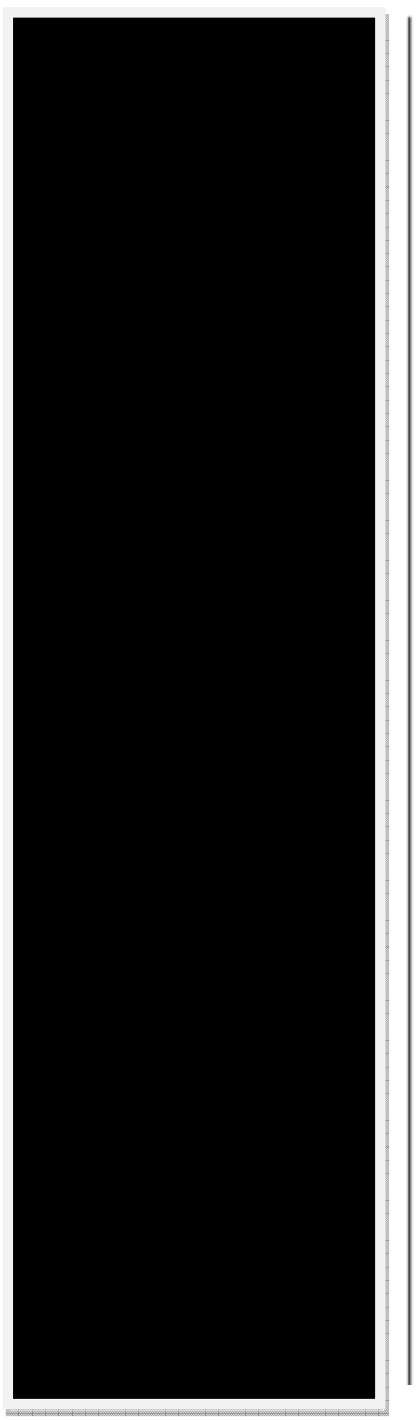

November 2, 2010

To Whom it May Concern:

Re: Shyrea Roberson and the University of Redlands Dissertation Research

In consideration of Ms. Shyrea Roberson's request to survey students in an alternative educational setting, I authorize permission for her to work with students at

for her dissertation research. as possible participants

If you need any further information, please contact me at

Respectfully,

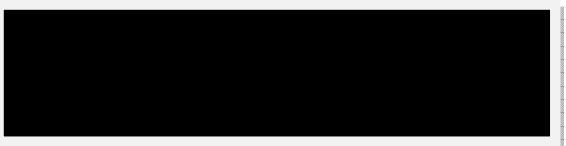

Director, Alternative Education 


\section{APPENDIX F SOME STUDENT RESPONSES TO OPEN-ENDED QUESTIONS}

23. In your own words, please explain how you feel so far about attending this school?

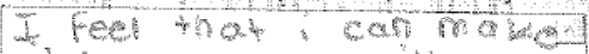

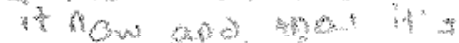

24. What steps are you taking to prepare for college/work after high school?

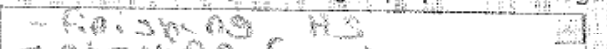

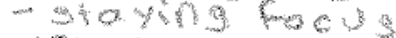

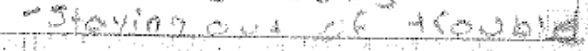

23. In your own yjords, please explain how you feel so far about attending this school?

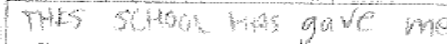

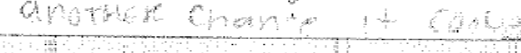

24. What steps are you taking to pepare for collegelwork after high schcoli

I. Dok tefun

1

23. in your own words, please explain how you feel so far about attending this school?

a big change who helpst rot

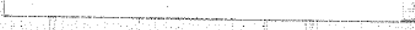

24. What steps are you taking to prepare for college/work atter high school?

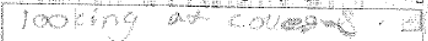



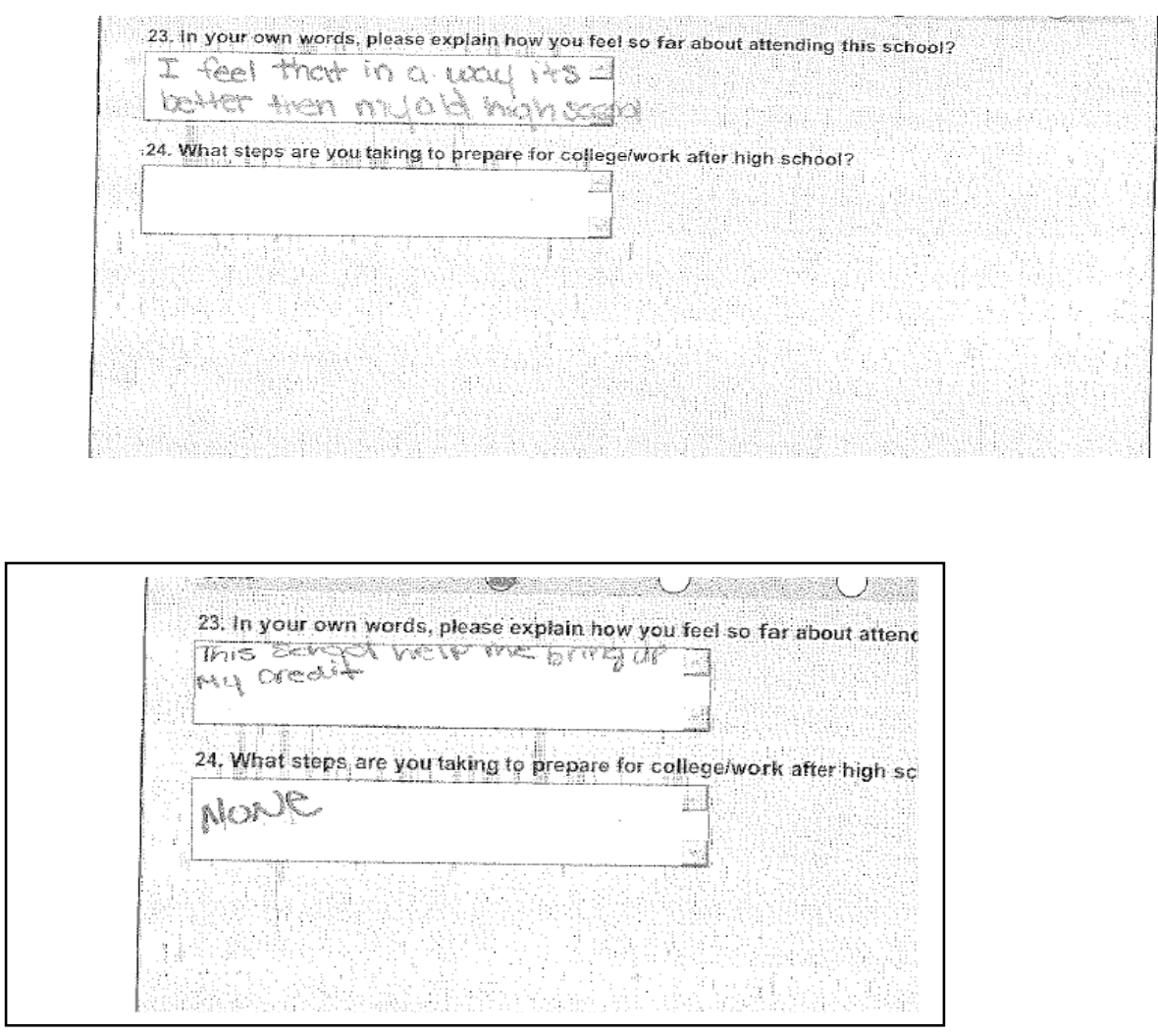